\title{
Mineralogie křemenných žil ložiska cínových rud Hřebečná u Abertam v Krušných horách (Česká republika)
}

\author{
Mineralogy of quartz veins of the tin deposit Hřebečná near Abertamy in Krušné hory \\ Mountains (Czech Republic)
}

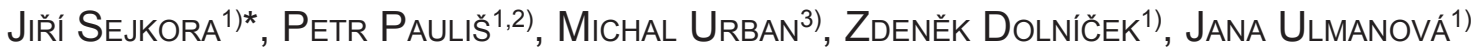 \\ A ONDŘEJ POUR ${ }^{4}$ \\ 1)Mineralogicko-petrologické oddělení, Národní muzeum, Cirkusová 1740, 19300 Praha 9 - Horní Počernice; \\ *e-mail: jiri.sejkora@nm.cz \\ 2) Smíškova 564, 28401 Kutná Hora \\ 3) Velké Kunratické 20, 14800 Praha 4 \\ 4)Česká geologická služba, Geologická 6, 15200 Praha 5
}

Sejkora J, Pauliš P, URban M, Dolniček Z, Ulmanová J, Pour O (2021) Mineralogie křemenných žil ložiska cínových rud Hřebečná u Abertam v Krušných horách. Bull Mineral Petrolog 29(1): 131-163 ISSN 2570-7337

\begin{abstract}
An extraordinary rich mineral assemblage (more than 35 determined mineral species) has been discovered in quartz greisen mineralization found at dump material of the abandoned Mauritius mine. This mine is situated about $1 \mathrm{~km} \mathrm{~N}$ of the Hřebečná village, $16 \mathrm{~km} \mathrm{~N}$ of Karlovy Vary, Krušné hory Mountains, Czech Republic. The studied mineralization with its textural and mineralogical character differs significantly from the usual fine-grained greisens mined in this area. The primary mineralization is represented by coarse-grained quartz and fluorapatite with sporadic zircon, monazite-(Ce), xenotime-(Y) and very rare cassiterite. Besides common sulphides (arsenopyrite, chalcopyrite, pyrite, sphalerite, tetrahedrite-group minerals), Bi-sulphosalts (aikinite, bismuthinite, berryite, cuprobismutite, emplectite, wittichenite) were determined. Members of the tetrahedrite group also contain increased amounts of $\mathrm{Bi}$ - in addition to Bi-rich tennantite- $(\mathrm{Zn})$ and tennantite-(Fe), microscopic zones represented by the not approved Bi-dominant analogue of tennantite (,annivite-(Zn)“) were also found. The primary mineralization was intensively affected by supergene processes. Chalcopyrite and sphalerite are replaced by $\mathrm{Cu}$ sulphides - especially anilite and digenite, and more rarely by geerite, spionkopite and covellite. Some of the fluorapatite grains in the vein quartz were decomposed and mrázekite, mixite, libethenite, pseudomalachite, hydroxylpyromorphite, metatorbernite as well as rare dzhalindite crystallized in the resulting cavities. However, the most abundant supergene phases are the minerals of the alunite supergroup - crandallite, goyazite, plumbogummite, svanbergite and waylandite. The detailed descriptions, X-ray powder diffraction data, refined unit-cell parameters and quantitative chemical composition of individual studied mineral phases are presented.
\end{abstract}

Key words: sulphides, Bi-sulphosalts, Bi-rich tennantite, supergene minerals, mrázekite, alunite supergroup minerals, Hřebečná near Abertamy, Krušné hory Mts., Czech Republic

Obdrženo 3. 5. 2021; prijjato 24. 6. 2021

\section{Úvod a historie těžby}

Dřive samostatná obec Hřebečná, dnes součást města Abertamy, je položena na jižně orientovaném mírném svahu asi 8 km zsz. od Jáchymova v Krušných horách. Obec $v$ minulosti proslula rozsáhlou těžbou cínových rud a produkcí cínu předčila, snad s výjimkou Krupky, všechny ostatní revíry českého Krušnohoří. Nejhlubším cínovým dolem tohoto regionu byl důl Mauritius, prohlášený v roce 2014 za národní kulturní památku.

I když kronika nedaleké Horní Blatné hovoří o tom, že těžba cínu na Hřebečné (Hengst, později až do roku 1948 Hengstererben) začala již kolem roku 1300, s jistotou Ize zdejší dolování sledovat až od poloviny 16. století. Konkrétně od roku 1545, kdy byl pravděpodobně založen důl Červená jáma (Rote Grube) na Přední Hřebečné, následovaný o něco málo později Behrovým dolem (podle prvního majitele Paula Behra) na tzv. Zadní Hřebečné, známým později pod jménem důl sv. Mauritia (Urban et al. 2014). Počátky hlubinného dolování na Behrově dole koncem 16. století jsou neprímo datovány značkami z roku 1588 na cínových rolích, které se našly v osmdesátých letech 20 . století ve vraku potopené holandské lodi u ostrova Texel (Hájek 2017).

Ačkoli revíry Přední a Zadní Hřebečná jsou od sebe vzdálené jen necelý kilometr, opakované pokusy o jejich propojení se nezdařily. V západní části ložiska na Přední Hřebečné sledovali staří horníci systém zhruba 15 greisenových žil směru SV - JZ až ZSZ - VJV, který se vějířovitě sbíhá v prostoru dolu Rote Grube (Červená jáma). Nejdůležitější z nich byla žíla Rothgrübner Hauptgang. $V$ těchto místech se dosud zachovaly velkolepé pinkové tahy, největší svého druhu v ČR. O odvodnění dolů se 
starala štola Jiří, která však vzhledem k ploché morfologii terénu odčerpávala vodu jen z hloubek okolo $60 \mathrm{~m}$. Přesto však vrty $z$ doby druhé světové války prokázaly báňskou činnost i v hloubce $70 \mathrm{~m}$ pod okrajem pinky dolu Červená jáma. Vedle nejvýznamnějšího dolu Rote Grube zde bylo množství menších dolů. Doly na Přední Hřebečné byly $v$ provozu od 16 . do konce 18 . století, později zde těžba již nikdy neprobíhala, přestože existovala řada studií, podle nichž tato část ložiska nebyla úplně vytěžena (Ježek 1933; Kratochvíl 1967). Naproti tomu na Zadní Hřebečné fungovaly doly od 16 . století téměř nepřetržitě po dobu 400 let. Nejvýznamnější byl důl Mauritius, kterým byly těženy především dvě hlavní greisenové žily Mauritius a Führinger (Ježek 1933; Urban ed. 2014).

Vrchol báňské činnosti na Přední i Zadní Hřebečné spadá do druhé poloviny 16. století, kdy zdejší produkce cínu byla značně vysoká a v nejlepších letech se mohla bližit 100 t ročně. Vyrobený cín byl velmi čistý a cínové ingoty se značkou Hřebečné byly vyváženy do mnoha států především západní Evropy. V sedmdesátých letech 16. století pracovalo na Hřebečné 46 dolů a ještě o 20 let později, kdy produkce ostatních revírů v okolí Horní Blatné a Božího Daru již zřetelně klesla, zde bylo v provozu kolem 30 - 35 dolů a $v$ činnosti byla též některá rýžoviska. Po roce 1610 dosahovala roční produkce $35-40 \mathrm{t}$, v roce 1621 klesla na 10 t cínu (Jangl 1975, 1988). Ve druhé polovině 17. století a během 18. století ještě na Přední Hřebečné živořilo několik jam na zbytcích chudých rud. Kolem poloviny 18 . století byly všechny doly na Přední Hřebečné opuštěny. Naproti tomu na Zadní Hřebečné na dole Mauritius se pracovalo na mohutných greisenových žilách téměř bez přestávek. Během třicetileté války a po ní sice i tento rudní revír zažil úpadek, ve třicátých letech 18. století však práce opět ožily a koncem 18 . století se

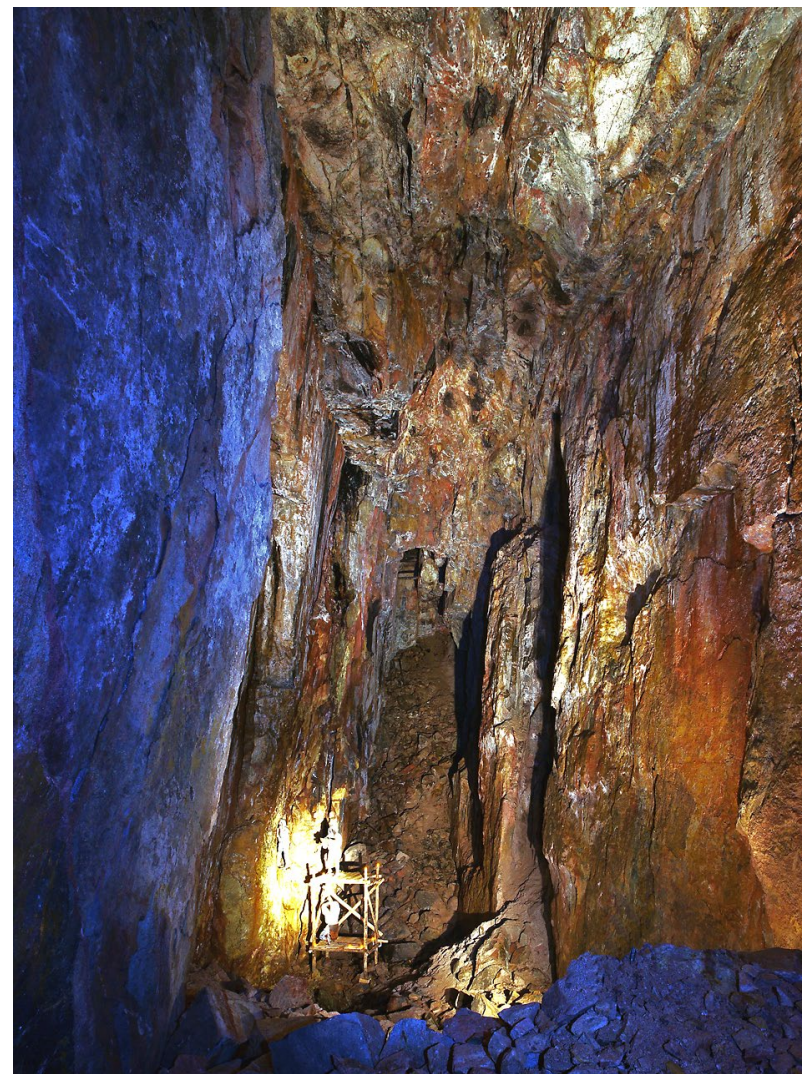

Obr. 1 Vytěžené komory v podzemí dolu Mauritius, foto J. Albrecht (2014). produkce cínu $v$ některých letech přiblížila maximům ze 16. století. $\vee 70$. letech 18 . století se ročně vyrobilo kolem 30 t cínu a v roce 1795 produkce vystoupala dokonce na $63 \mathrm{t}$ (Ježek 1933). $V$ tu dobu zde pracovalo několik stoup na drcení rudy, cínová a od roku 1773 také arzénová hut', kovárna a vznikly tu i dva větší důlní rybníky, do nichž byla priváděna voda ze vzdálenosti $2.5 \mathrm{~km}$ z Mrtvého (původně Behrova či Mauritiova) rybníku pod Božídarským Špičákem. Další početné stoupy pak pracovaly v údolí Bystřice ve spodní části Hřebečné zvané Grund (Schaller 1785; Urban, Malina 2013). O odvodňování dolů se staralo několik štol. V nejstarším období to byly (shora) Tagstrecke, Kryštof a Festenburská. V období druhé konjunktury těžby $v$ 18. století převzala tuto úlohu dědičná štola Blasius, ražená od roku 1751 z údolí Bystřice. Tato štola dosáhla celkové délky téměř $1600 \mathrm{~m}$ a na severu dosáhla až k východozápadní poruše Fäule, na níž ložisko v podstatě končí (Günther 1857; Ježek 1933).

Na počátku 19. století se množství cínu vytěženého $v$ dole Mauritius začalo snižovat. Namísto pravidelné těžby navíc po roce 1810 došlo k rabování ložiska - byly dotěžovány zbytky rud zachované $v$ bezpečnostních piliŕích a vyrubány stropy mezi patry. Tím byla narušena dosavadní pravidelnost důlního díla a vznikly ohromné podzemní komory (obr. 1). Dưl poté pracoval se značnými výkyvy a v některých letech byl dokonce uzavřen. Průměrná roční výroba ve 20. - 50. letech 19. století činila jen 5 - 10 t cínu. Pravděpodobně v roce 1858 koupil důl horní prísežný ze saského Johanngeorgenstadtu Theodor William Tröger. $\checkmark$ tomtéž roce je doloženo založení těžařstva Mauritius. Většina štol patřících $\mathrm{k}$ dolu včetně dědičné štoly Blasius však byla z velké části zavalena (Ježek 1933). Trögerův syn Rudolph pak v roce 1878 prodal celý důlní závod britské důlní společnosti za 130000 zlatých. Ta v následujících letech vybavila důl moderním anglickým zařizením, do dolu byla zavedena i elektřina. $V$ roce 1881 byl na dole v provozu parní těžní stroj a různé typy gravitačních stolů (Nesrsta et al. 2015). V roce 1883 nařídila společnost zastavení tavby $v$ prostoru dolu a ruda byla nadále posílána ke zpracování do Cornwallu. Koncem dubna 1891 Angličané práce $z$ finančních důvodů zastavili. Za dobu jejich působení se vyrobilo asi 100 t cínu. Opuštěný důl přešel v roce 1909 do majetku abertamského těžařstva Gewerkschaft für Zinnerzbergbau (obr. 2), které v závěru 1. světové války a krátce po ní podniklo řadu zmáhacích a průzkumných prací a po několikaleté pauze podnikalo i na počátku 30 . let, kdy byla opět otevřena dědičná štola Blasius. Toto těžařstvo po celou dobu usilovalo o prodej dolu kapitálově silnějšímu investorovi. To se mu podařilo až ve druhé polovině 30 . let, kdy se majitelem dolu stala opět britská společnost British and Continental Mining Corporation, která již vlastnila doly v okolí Horního Slavkova. Ta však byla nucena již v roce 1938 postoupit důl berlínskému Reichsamt für Bodenforschung, od něhož ho převzalo těžařstvo Gewerkschaft Zinnwalder Bergbau z Altenbergu. To přistoupilo během okupace k novému vyzmáhání dolu a otevřelo ložisko na hlubších patrech. Nad hlavní těžní jamou byla vybudována nová těžní věž, která sem byla po kusech přepravena z východních Krušných hor z dolu v Berggiesshübelu. Hlavní šachta Mauritius, která byla až do 40. let 20. století hluboká $84 \mathrm{~m}$ ( $v$ této hloubce ji zastihuje štola Blasius), byla za války prohloubena až do 145 m (obr. 3). Němci zde do listopadu 1944 provedli poměrně rozsáhlý průzkum zaměřený na ověření zásob rudy pod úrovní štoly Blasius. Průzkum však zůstal nedokončen, protože se zjistilo, že staré důlní práce za- 
sahují ještě minimálně $20 \mathrm{~m}$ pod patro $-145 \mathrm{~m}$ (do hloubky přes $220 \mathrm{~m}$ ) (Jangl 1975, 1988; Urban ed. 2014).

Po válce byly podniknuty již pouze vyhledávací průzkumné práce v letech 1955 - 1958 a 1963 - 1973, které potvrdily kvalitní vývoj zrudnění až do hloubek -200 m, níže však obsahy cínu klesaly na minimum. $\checkmark$ roce 1963 byla odstraněna dřevěná těžní věž a ústí jámy bylo opatřeno ocelovým roštem. Celkem je na Hřebečné dosud vedeno zhruba 26 tisíc $t$ zásob $s$ průměrným obsahem $0.79 \%$ Sn, což odpovídá 200 tunám čistého kovu (Knížková-Drbohlavová et al. 1970). Celkové množství cínu vytěženého na Hřebečné odhadl Urban (2015) na minimálně 10500 tun.

Hřebečná s doly Mauritius (obr. 4) a Rote Grube je součástí hornické krajiny Abertamy - Boží Dar - Horní Blatná, která je jednou z pěti českých lokalit, které byly $v$ rámci Hornického regionu Krušné hory/Erzgebirge zapsány v roce 2019 na Seznam světového dědictví UNESCO. Je také součástí Národního geoparku Egeria.

\section{Geologická pozice lokality}

Ložisko Hřebečná je situováno v jv. části blatenského žulového masívu, při jeho kontaktu s fylitovým komplexem spodnopaleozoického stáŕí. Blatenský masív má na povrchu zhruba tvar trojúhelníku situovaného na ploše zhruba $12 \mathrm{~km}^{2}$ mezi Horní Blatnou na západě, Hřebečnou na východě a Pískovcem na severu. Jde o složenou intruzi, která je tvořena několika různými typy vysoce frakcionovaných peraluminických $\mathrm{Li}, \mathrm{F}$ a P-bohatých granitů. Jednotlivé regionální výskyty (Jelení vrch, Blatenský vrch, Hřebečná, Sněžná hůrka, Luhy, Pila, Pískovec a Podlesí) se liší v modálním a chemickém složení i v textuře a pokrývají škálu od jemnozrnných

Obr. 2 Zděná šachetní budova dolu Mauritius na Hřebečné $v$ roce 1910 (archiv M. Urbana).

Obr. 3 Dřevěná věž dolu Mauritius na Hřebečné, úplně vlevo strojovna, po obou stranách těžní věže, sklady a provozní budovy (1946), foto R. Hylský, fotoarchiv České geologické služby.

Obr. 4 Zrekonstruované ústí štoly Kryštof dolu Mauritius, foto P. Pauliš (2014).
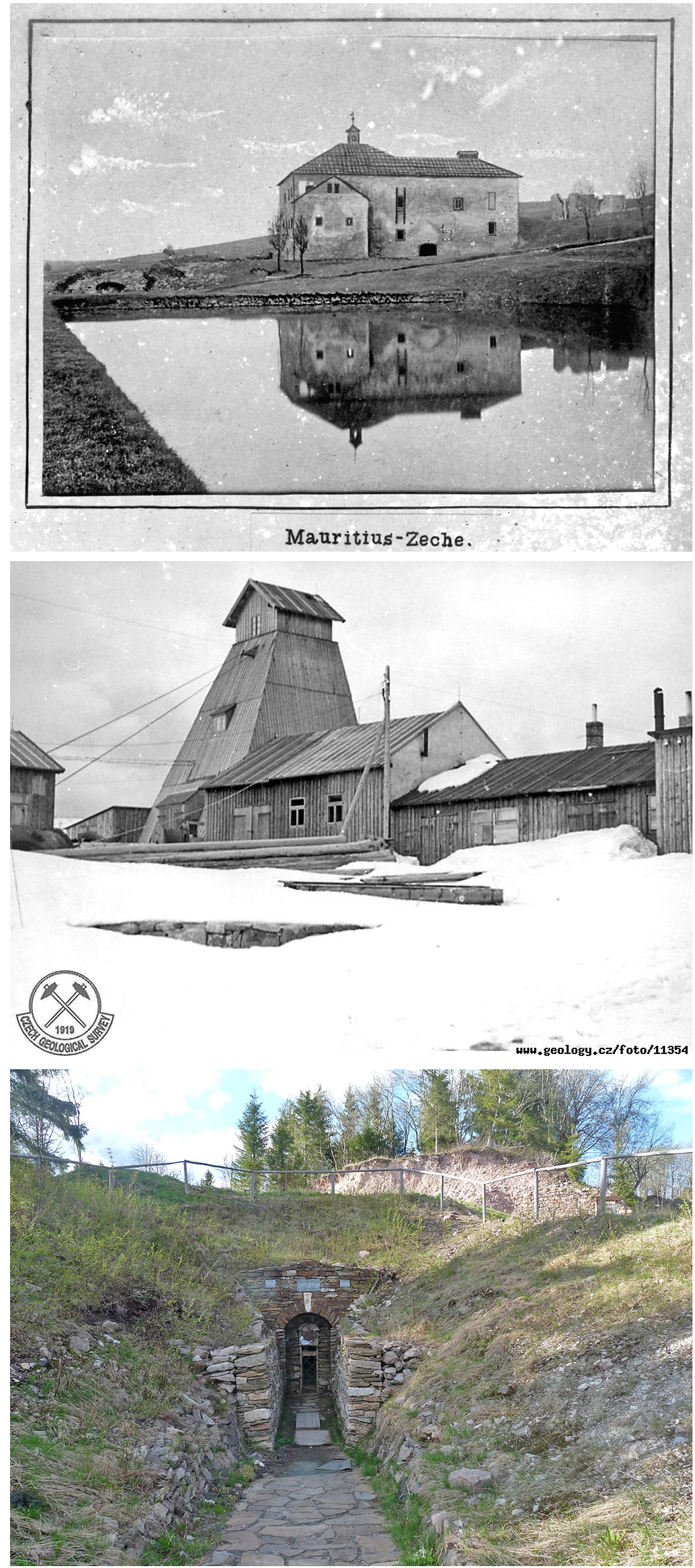
afyrických i porfyrických k hrubozrnným typům. Všechny dosud zjištěné greiseny blatenského masívu jsou žilného charakteru, s naprosto převažujícím kasiteritovým zrudněním. Wolframit byl zjištěn pouze v suti na sv. svahu Blatenského vrchu. $V$ některých žilách (Dušičky, Sněžná hůrka - západ) je lokálně vyvinuto bohaté sulfidické zrudnění s arzenopyritem, löllingitem, chalkopyritem, bornitem a chalkozínem (Breiter et al. 1985, 1987).

Vlastní ložisko Hřebečná tvoří greisenové zóny obohacené Sn a As. Greiseny jsou vyvinuté převážně podle ploch starších puklin a tvoří několik subvertikálních žilných tahů. $V$ typickém vývoji mají zonalitu od greiseni-

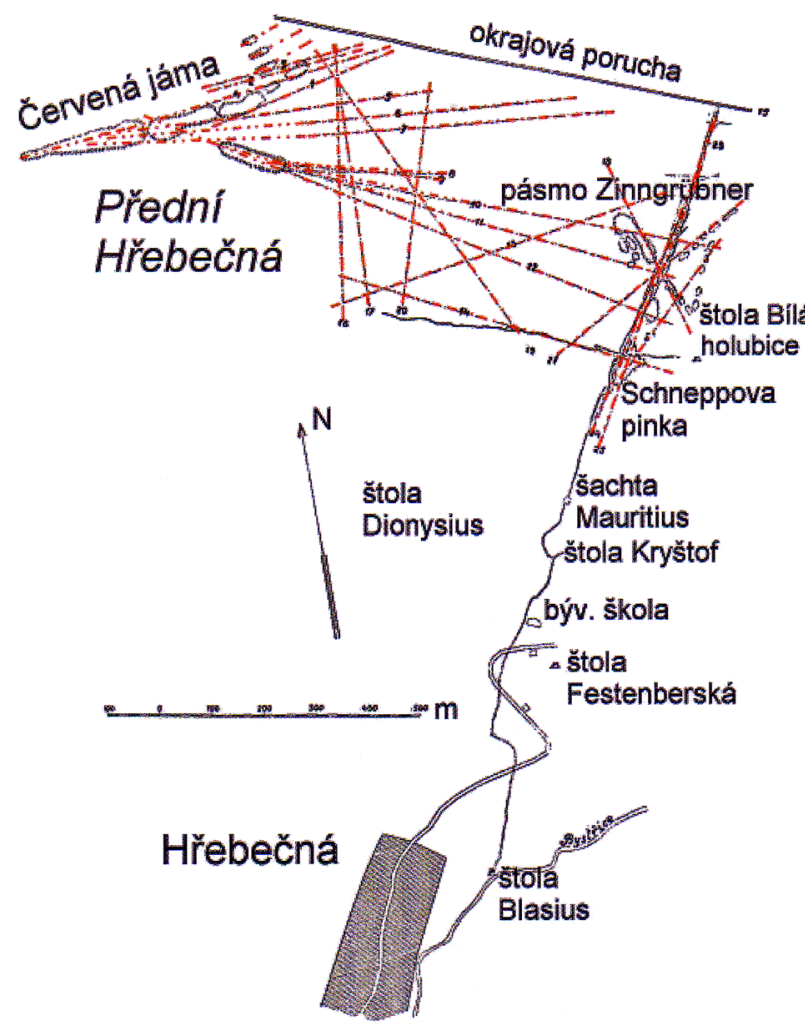

Obr. 5 Hlavní důlní díla na Hřebečné podle Urbana ed. (2014).

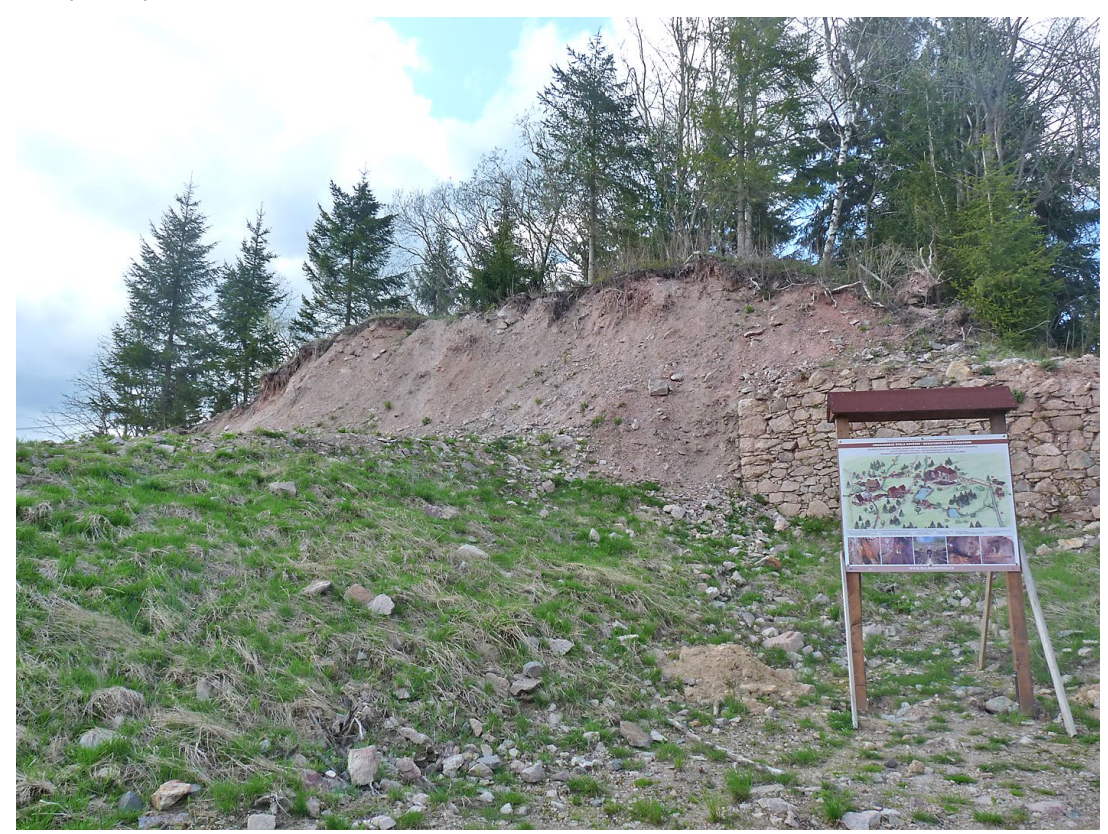

Obr. 6 Odval u jámy dolu Mauritius, foto P. Pauliš (2015). zovaných granitů přes slídnato-křemenné greiseny směrem k topaz-křemenným a monominerálním křemenným typům (Knížková-Drbohlavová et al. 1970; Škvor 1975; Heřmanská 2013; Urban, Malina 2013). Kromě toho se objevují drobné křemen-kasiteritové žilky, které mají poměrně vysoký obsah cínu.

$\checkmark$ prostoru Zadní Hřebečné (obr. 5) je zrudnění vázáno hlavně na struktury směru SSV - JJZ se strmým úklonem k ZSZ (hlavní žíly Mauritius a Führinger). Tyto téměř vertikální greisenové polohy s vysokým obsahem kasiteritu probíhaly jen $v$ malé vzdálenosti od sebe (obvykle 3 - $5 \mathrm{~m}$ ), přičemž jejich maximální souhrnná mocnost dosahovala až $16 \mathrm{~m}$ a těženy byly až do hloubek okolo 220 $m$. V severní části ložiska se tyto hlavní žily křiží se žílou Zinngrübner směru SZ - JV a žílami Alter Johannes (SV - JZ), Drei Brüder (SSV - JJZ) a Dreifaltigkeit a Heiliger Kreuz (SV - JZ). Na všech kříženích vyrazili staří horníci velkolepé podzemní komory, z nichž největší, nacházející se nad i pod úrovní Festenburské štoly, je jen v nezatopené partii dolu $60 \mathrm{~m}$ dlouhá, $40 \mathrm{~m}$ vysoká a $15 \mathrm{~m}$ široká (Urban ed. 2014). Na Přední Hřebečné byla sledována celá řada zrudněných struktur různých směrů. Nejdůležitější jsou SSZ - JJV, ZJZ - VSV a ZSZ - VJV, také zde se prritom nejbohatší zrudnění vyskytovalo $v$ místech křižení žil. Směrem do hloubky ubývá cínu a přibývá arsenu (Jangl et al. 1989).

Přes značné rozfárání revíru a jeho značný význam jsou znalosti o jeho mineralogii dosti skromné. Kromě nemnoha starších pramenů shrnutých J. Kratochvílem (1958) pocházejí souhrnnější informace o minerálech Hřebečné v podstatě pouze od jeho jmenovce F. Kratochvíla (1965).

Hlavní rudní minerál kasiterit se v makroskopické podobě vyskytuje již jen vzácně, nebot' bohaté partie byly v minulosti vytěženy. Černohnědé, ale i žluté krystaly kasiteritu o velikosti do $5 \mathrm{~mm}$, uzavřené $v$ křemeni a bělavé jílové hmotě, obsahovaly $0 . X \% \mathrm{Fe}$ a Ti a nízké koncentrace $(0.0 X \%)$ In, Sc, W a Zr (Novák, Zahradník 1962). Podle nových analýz zastupuje část cínu titan (až $1.15 \mathrm{hm}$.

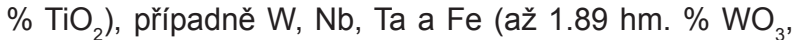
$1.24 \mathrm{hm} . \% \mathrm{Ta}_{2} \mathrm{O}_{5}, 1.42 \mathrm{hm} . \% \mathrm{Nb}_{2} \mathrm{O}_{5}$ a $0.82 \mathrm{hm}$. \% FeO; Heřmanská 2013). Průměrný obsah cínu v těžené rudě se pohyboval kolem $0.5 \%$, ještě na počátku minulého století však byly získávány rudy i s obsahem 2 - $4 \% \mathrm{SnO}_{2}$ a nejbohatší partie obsahovaly přes $20 \%$ Sn (Ježek 1933). Kratochvíl (1965) zmiňuje $\mathrm{z}$ dolu Mauritius až $1.9 \mathrm{~mm}$ velké krystaly kasiteritu a jeho zrnité agregáty. Součástí greisenových poloh bývá vedle běžných horninotvorných minerálů a kasiteritu také topaz, tvořící i ojedinělé krystaly, a fialový fluorit. Greiseny pronikají mléčně bílé drobné žíly křemene, který bývá často drúzovitý s až několik $\mathrm{cm}$ velkými krystaly. Místy se $v$ něm objevuje světle fialový ametyst, tvořící drobné sloupcovité krystaly. Vzácnější je záhnědový křemen. Z dobývek dolu Mauritius jsou uváděny rưžicovité agregáty a až $7 \mathrm{~cm}$ velké shluky hematitu s limonitem. Z greisenů dolu Mauritius dále Kratochvíl (1965) uvádí vzácné, až 3 mm velké krystaly pyritu, ojedinělý chalkopyrit, chalkozín s povlaky malachitu, skoryl a drobné lupínky torbernitu. Autunit 
a torbernit z Hřebečné zmiňuje již Laube (1876), torbernit $z$ odvalů u dolu Mauritius uvádí též Komárek (1965, 1968) a byl nově nalezen i v prohlídkové štole Kryštof. Zajímavým a poměrně hojným minerálem je apatit, který je uváděn jako zelené či šedobílé, tlustě i tence sloupcovité nedokonalé krystaly do $15 \mathrm{~mm}$, jako poměrně časté zrnité agregáty namodralé či bělavé barvy se zřetelnou zonálností a jako hnědé až béžové paprsčité agregáty stébel do $3 \mathrm{~cm}$ na styku „dřeňku“ se žilným křemenem (Tuček 1948).

\section{Metodika výzkumu}

Povrchová morfologie vzorků byla sledována $v$ dopadajícím světle pomocí optického mikroskopu Nikon SMZ 1000 (Národní muzeum Praha); tento mikroskop byl použit také pro separaci jednotlivých fází pro další výzkum. Nábrusy studovaných vzorků byly pro výzkum v odraženém světle a následné chemické analýzy připraveny standardním leštěním diamantovou suspenzí. Optické vlastnosti rudních minerálů $v$ odraženém světle byly studovány pomocí mikroskopu Nikon Eclipse ME600 s digitální kamerou Nikon DXM1200F.

Rentgenová prášková difrakční data studovaných minerálů byla získána pomocí práškového difraktometru Bruker D8 Advance (Národní muzeum, Praha) s polovodičovým pozičně citlivým detektorem LynxEye za užití CuKa záření (40kV, 40 mA). Práškové preparáty byly naneseny $v$ acetonové suspenzi na nosič zhotovený z monokrystalu křemíku a následně pak byla pořízena difrakční data ve step-scanning režimu (krok $0.01^{\circ}$, načítací čas $8 \mathrm{~s} /$ krok detektoru, celkový čas experimentu cca 15 hod.). Získaná data byla vyhodnocena pomocí softwaru ZDS pro DOS (Ondruš 1993) za použití profilové funkce Pearson VII. Zjištěná rentgenová prášková data byla indexována na základě teoretických záznamů vy- počtených programem Lazy Pulverix (Yvon et al. 1977) z publikovaných krystalových strukturních dat, parametry základních cel byly následně zpřesněny pomocí programu Burnhama (1962).

Chemické složení bylo kvantitativně studováno pomocí elektronového mikroanalyzátoru Cameca SX100

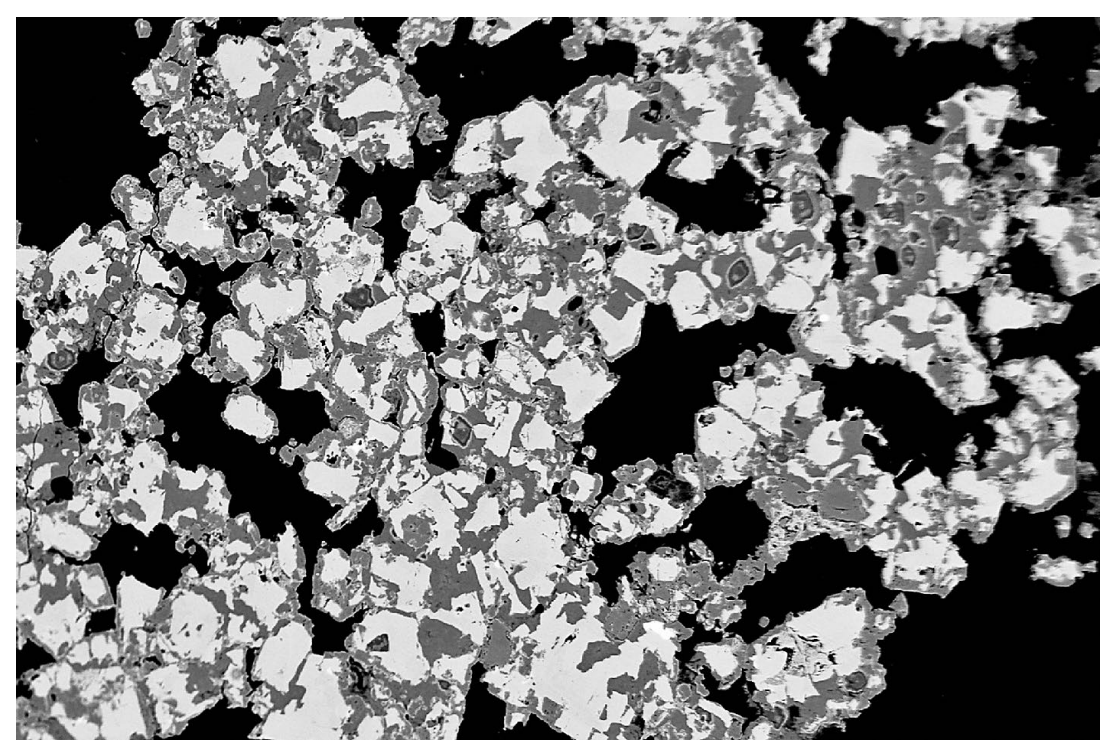

Obr. 7 Zrna arsenopyritu (bílý) tmelená pyritem (šedý); Hřebečná; šířka záběru $1000 \mu \mathrm{m}$, BSE foto Z. Dolníček.

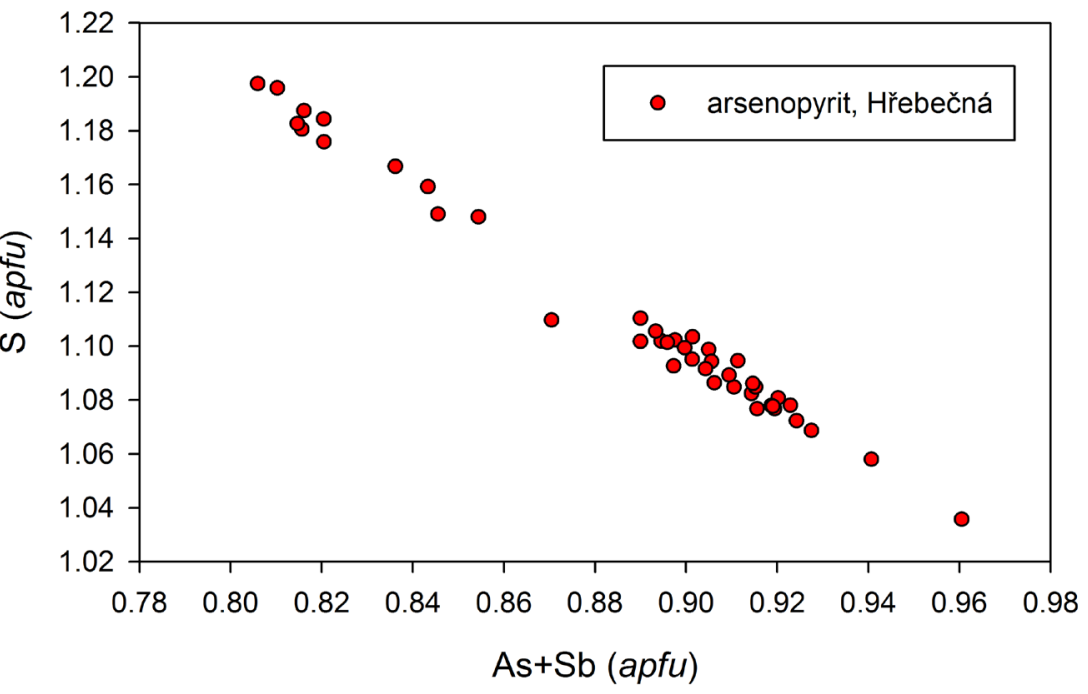

Obr. 8 Graf (As+Sb) vs. S (apfu) pro arsenopyrit z Hřebečné.

Tabulka 1 Chemické složení arsenopyritu z Hřebečné ( $h m$. \%)

\begin{tabular}{|c|c|c|c|c|c|c|c|c|c|c|c|c|c|c|}
\hline & 1 & 2 & 3 & 4 & 5 & 6 & 7 & 8 & 9 & 10 & 11 & 12 & 13 & 1 \\
\hline & 5.18 & .31 & 5.22 & .87 & 35.37 & 3544 & 34.91 & 3561 & 5.34 & 3 & 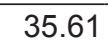 & 35 & 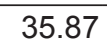 & 3610 \\
\hline 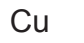 & & 09 & & & & & & & & & & & & 0.2 \\
\hline b & & 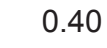 & 7 & & & & & & 26 & & & & & .2 \\
\hline & 16 & 62 & 42.96 & 12 & 42.55 & & 42.46 & & 12.48 & & & & & .28 \\
\hline & .84 & .63 & 21.78 & 4 & 8 & & 0 & & 2.41 & & 4.03 & & & 5.0 \\
\hline tal & .18 & 1.05 & 00.73 & 0.57 & 0.91 & 0.88 & 00.76 & 101.09 & 00.58 & 99.20 & 00.98 & 100.54 & 100.49 & 100.90 \\
\hline & & 2 & 001 & 1 & 999 & & & & 8 & & 0986 & & & 990 \\
\hline & 00 & 02 & רחת & 06 & 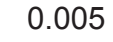 & & & & 002 & & & & & 0.00 \\
\hline & & 05 & & & & & & & 03 & & 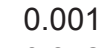 & & & .003 \\
\hline & & & & & & & & & & & & & & 0.803 \\
\hline & .036 & 1.069 & 1.078 & 1.085 & 1.092 & 1.094 & 1.099 & 1.101 & 1.102 & 1.110 & 1.159 & 1.167 & 1.188 & 1.198 \\
\hline
\end{tabular}

1-14 reprezentativní analýzy; koeficienty empirických vzorců počítány na bázi 3 apfu. 
Tabulka 2 Chemické složení chalkopyritu a pyritu z Hřebečné (hm. \%)

\begin{tabular}{lrrrrrrrrrrrrrr}
\hline & \multicolumn{1}{c}{ chalkopyrit } & 10 & 10 & pyrit \\
\hline & 1 & 2 & 3 & 4 & 5 & 6 & 7 & 8 & 9 & 10 & 11 & 12 & 13 & 14 \\
\hline $\mathrm{Fe}$ & 29.80 & 30.26 & 30.26 & 42.42 & 43.24 & 44.90 & 45.23 & 46.17 & 45.52 & 42.29 & 45.31 & 45.96 & 45.35 & 47.25 \\
$\mathrm{~Pb}$ & 0.00 & 0.00 & 0.00 & 0.16 & 0.13 & 0.17 & 0.15 & 0.12 & 0.20 & 0.25 & 0.19 & 0.15 & 0.18 & 0.21 \\
$\mathrm{Cu}$ & 35.21 & 34.35 & 35.44 & 5.27 & 4.04 & 1.23 & 0.52 & 0.20 & 0.25 & 4.94 & 1.50 & 0.70 & 0.62 & 0.20 \\
$\mathrm{As}$ & 0.00 & 0.00 & 0.00 & 0.00 & 0.14 & 0.00 & 2.97 & 0.74 & 3.27 & 2.41 & 0.00 & 0.00 & 2.42 & 0.00 \\
$\mathrm{~S}$ & 35.59 & 35.41 & 34.64 & 50.78 & 51.33 & 53.10 & 50.98 & 52.72 & 50.76 & 50.21 & 53.56 & 54.06 & 52.50 & 54.17 \\
\hline total & 100.60 & 100.02 & 100.34 & 98.63 & 98.88 & 99.40 & 99.85 & 99.95 & 100.00 & 100.10 & 100.56 & 100.87 & 101.07 & 101.83 \\
\hline $\mathrm{Fe}$ & 0.971 & 0.991 & 0.994 & 0.939 & 0.951 & 0.972 & 0.992 & 0.998 & 0.999 & 0.933 & 0.971 & 0.979 & 0.977 & 0.999 \\
$\mathrm{~Pb}$ & 0.000 & 0.000 & 0.000 & 0.001 & 0.001 & 0.001 & 0.001 & 0.001 & 0.001 & 0.001 & 0.001 & 0.001 & 0.001 & 0.001 \\
$\mathrm{Cu}$ & 1.008 & 0.989 & 1.023 & 0.103 & 0.078 & 0.023 & 0.010 & 0.004 & 0.005 & 0.096 & 0.028 & 0.013 & 0.012 & 0.004 \\
$\mathrm{As}$ & 0.000 & 0.000 & 0.000 & 0.000 & 0.002 & 0.000 & 0.049 & 0.012 & 0.054 & 0.040 & 0.000 & 0.000 & 0.039 & 0.000 \\
$\mathrm{~S}$ & 2.020 & 2.020 & 1.982 & 1.958 & 1.967 & 2.003 & 1.948 & 1.985 & 1.941 & 1.930 & 1.999 & 2.007 & 1.971 & 1.996 \\
\hline $1-3$ reprezentativní analýzy chalkopyritu, 4-14 pyritu; koeficienty empirických vzorců počítány na bázi 4 apfu (chalko- \\
pyrit), 3 apfu (pyrit).
\end{tabular}

Tabulka 3 Chemické složení sfaleritu z Hřebečné (hm. \%)

\begin{tabular}{|c|c|c|c|c|c|c|c|c|c|c|c|c|c|c|}
\hline & 1 & 2 & 3 & 4 & 5 & 6 & 7 & 8 & 9 & 10 & 11 & 12 & 13 & 14 \\
\hline $\mathrm{Fe}$ & 0.06 & 0.18 & 0.21 & 0.25 & 0.30 & 0.31 & 0.75 & 2.49 & 4.48 & 4.63 & 4.81 & 5.00 & 5.19 & 5.54 \\
\hline $\mathrm{Cd}$ & 0.70 & 0.51 & 0.53 & 0.88 & 1.15 & 1.14 & 0.33 & 0.54 & 0.50 & 0.52 & 0.58 & 0.58 & 0.52 & 0.50 \\
\hline In & 0.00 & 0.20 & 0.12 & 0.05 & 0.00 & 0.00 & 0.08 & 0.48 & 0.46 & 0.42 & 0.09 & 0.12 & 0.19 & 0.22 \\
\hline $\mathrm{Zn}$ & 63.51 & 63.80 & 64.82 & 62.27 & 63.38 & 61.48 & 64.02 & 62.73 & 60.92 & 60.70 & 60.93 & 60.30 & 60.27 & 59.97 \\
\hline $\mathrm{Cu}$ & 3.80 & 2.29 & 1.85 & 3.90 & 2.24 & 4.93 & 2.08 & 0.44 & 1.00 & 0.90 & 0.50 & 0.84 & 0.18 & 0.47 \\
\hline S & 32.90 & 32.87 & 33.20 & 32.83 & 32.99 & 32.97 & 33.31 & 33.09 & 33.26 & 33.27 & 33.90 & 33.71 & 33.21 & 33.24 \\
\hline total & 100.97 & 99.85 & 100.73 & 100.18 & 100.06 & 100.83 & 100.57 & 99.77 & 100.61 & 100.43 & 100.81 & 100.55 & 99.56 & 99.94 \\
\hline $\mathrm{Fe}$ & 0.001 & 0.003 & 0.004 & 0.004 & 0.005 & 0.005 & 0.013 & 0.043 & 0.077 & 0.080 & 0.082 & 0.086 & 0.090 & 0.096 \\
\hline $\mathrm{Cd}$ & 0.006 & 0.004 & 0.005 & 0.008 & 0.010 & 0.010 & 0.003 & 0.005 & 0.004 & 0.004 & 0.005 & 0.005 & 0.004 & 0.004 \\
\hline In & 0.000 & 0.002 & 0.001 & 0.000 & 0.000 & 0.000 & 0.001 & 0.004 & 0.004 & 0.004 & 0.001 & 0.001 & 0.002 & 0.002 \\
\hline $\mathrm{Zn}$ & 0.941 & 0.954 & 0.960 & 0.929 & 0.946 & 0.912 & 0.947 & 0.935 & 0.899 & 0.897 & 0.892 & 0.886 & 0.895 & 0.888 \\
\hline $\mathrm{Cu}$ & 0.058 & 0.035 & 0.028 & 0.060 & 0.034 & 0.075 & 0.032 & 0.007 & 0.015 & 0.014 & 0.008 & 0.013 & 0.003 & 0.007 \\
\hline S & 0.994 & 1.002 & 1.003 & 0.999 & 1.004 & 0.997 & 1.005 & 1.006 & 1.001 & 1.002 & 1.012 & 1.010 & 1.006 & 1.003 \\
\hline
\end{tabular}

Tabulka 4 Chemické složení tennantitu-(Zn) z Hřebečné (hm. \%)

\begin{tabular}{|c|c|c|c|c|c|c|c|c|c|c|c|c|c|c|}
\hline & 1 & 2 & 3 & 4 & 5 & 6 & 7 & 8 & 9 & 10 & 11 & 12 & 13 & 14 \\
\hline $\mathrm{Ag}$ & 0.10 & 0.10 & 0.10 & 0.17 & 0.14 & 0.09 & 0.11 & 0.10 & 0.12 & 0.00 & 0.13 & 0.15 & 0.18 & 0.16 \\
\hline $\mathrm{Fe}$ & 2.22 & 2.99 & 2.57 & 2.87 & 1.72 & 2.63 & 0.99 & 1.42 & 1.20 & 2.63 & 2.80 & 2.34 & 1.07 & 2.55 \\
\hline $\mathrm{Pb}$ & 0.00 & 0.00 & 0.00 & 0.00 & 0.00 & 0.00 & 0.00 & 0.00 & 0.00 & 0.00 & 0.00 & 0.00 & 0.00 & 0.00 \\
\hline $\mathrm{Cd}$ & 0.00 & 0.06 & 0.05 & 0.07 & 0.00 & 0.06 & 0.00 & 0.00 & 0.00 & 0.43 & 0.00 & 0.00 & 0.00 & 0.10 \\
\hline $\mathrm{Zn}$ & 6.63 & 5.99 & 6.52 & 6.01 & 6.86 & 6.86 & 7.54 & 7.39 & 7.41 & 3.58 & 6.98 & 7.10 & 7.11 & 6.46 \\
\hline $\mathrm{Cu}$ & 40.95 & 40.48 & 39.79 & 39.58 & 39.39 & 37.89 & 38.64 & 38.07 & 37.98 & 39.78 & 36.62 & 36.91 & 37.03 & 35.67 \\
\hline $\mathrm{Sb}$ & 32 & 0.76 & 0.54 & 0.94 & 0.68 & 0.15 & 1.70 & 1.28 & 1.00 & 0.07 & 1.01 & 0.97 & 0.78 & 1.63 \\
\hline $\mathrm{Bi}$ & 1.86 & 7.33 & 8.93 & 9.67 & 10.93 & 12.43 & 13.72 & 14.41 & 16.11 & 18.14 & 17.98 & 18.44 & 19.57 & 20.86 \\
\hline As & 18.57 & 16.52 & 14.88 & 14.31 & 14.74 & 13.05 & 12.25 & 12.13 & 11.19 & 10.63 & 10.30 & 9.83 & 9.41 & 8.02 \\
\hline $\mathrm{S}$ & 27.79 & 26.39 & 26.83 & 26.29 & 25.75 & 26.23 & 25.07 & 25.10 & 25.13 & 25.52 & 24.41 & 24.12 & 24.73 & 24.81 \\
\hline total & 99.44 & 100.62 & 100.21 & 99.91 & 100.21 & 99.39 & 100.02 & 99.90 & 100.14 & 100.77 & 100.23 & 99.86 & 99.88 & 100.26 \\
\hline$\overline{\mathrm{Ag}}$ & 0.014 & 0.014 & 0.014 & 0.025 & 0.021 & 0.013 & 0.017 & 0.015 & 0.018 & 0.000 & 0.020 & 0.024 & 0.028 & 0.025 \\
\hline $\mathrm{Fe}$ & 0.600 & 0.831 & 0.719 & 0.813 & 0.492 & 0.758 & 0.291 & 0.418 & 0.356 & 0.778 & 0.842 & 0.710 & 0.325 & 0.778 \\
\hline $\mathrm{Cd}$ & 0.000 & 0.008 & 0.007 & 0.010 & 0.000 & 0.009 & 0.000 & 0.000 & 0.000 & 0.063 & 0.000 & 0.000 & 0.000 & 0.015 \\
\hline $\mathrm{Zn}$ & 1.531 & 1.422 & 1.559 & 1.454 & 1.677 & 1.688 & 1.893 & 1.860 & 1.876 & 0.904 & 1.792 & 1.839 & 1.845 & 1.684 \\
\hline $\mathrm{Cu}$ & 9.729 & 9.887 & 9.785 & 9.853 & 9.906 & 9.593 & 9.979 & 9.856 & 9.893 & 10.335 & 9.674 & 9.837 & 9.887 & 9.563 \\
\hline $\mathrm{Sb}$ & 0.164 & 0.097 & 0.069 & 0.122 & 0.089 & 0.020 & 0.229 & 0.173 & 0.136 & 0.009 & 0.139 & 0.135 & 0.109 & 0.228 \\
\hline $\mathrm{Bi}$ & 0.134 & 0.544 & 0.668 & 0.732 & 0.836 & 0.957 & 1.077 & 1.134 & 1.276 & 1.433 & 1.444 & 1.494 & 1.589 & 1.701 \\
\hline As & 3.742 & 3.422 & 3.104 & 3.021 & 3.144 & 2.802 & 2.683 & 2.664 & 2.472 & 2.342 & 2.308 & 2.222 & 2.131 & 1.824 \\
\hline$\underline{S}$ & 13.085 & 12.774 & 13.076 & 2.970 & 12.834 & 13.161 & 12.831 & 12.879 & 12.973 & 13.137 & 12.780 & 12.740 & 13.086 & 13.18 \\
\hline
\end{tabular}


(vlnově disperzní analýza) za podmínek pro sulfidy: urychlovací napětí $25 \mathrm{kV}$, proud elektronového svazku $20 \mathrm{nA}$, průměr svazku $1 \mu \mathrm{m}$; použité standardy a analytické čáry: $\mathrm{Ag}$ $(\mathrm{Ag} L \alpha), \mathrm{Au}(\mathrm{AuM \alpha}), \mathrm{Bi}_{2} \mathrm{Se}_{3}(\mathrm{Bi} M \beta)$, CdTe $(\mathrm{Cd} L \alpha)$, Co $(\mathrm{CoK} \alpha)$, CuFeS (CuKa, SKa), $\mathrm{FeS}_{2}(\mathrm{FeK} \alpha), \mathrm{GaAs}$ $(\mathrm{GaL} \alpha)$, Ge $(\mathrm{Ge} L \alpha)$, HgTe $(\mathrm{Hg} L \alpha)$, InAs $(\operatorname{In} L \alpha), \mathrm{Mn}(\mathrm{MnK} \alpha), \mathrm{NaCl}(\mathrm{Cl} K \alpha)$, NiAs $(\mathrm{As} L \beta)$, Ni $(\mathrm{NiK} \alpha)$, $\mathrm{PbS}(\mathrm{PbM} \alpha)$, $\mathrm{PbSe}(\mathrm{Se} L \beta), \mathrm{PbTe}(\mathrm{Te} L \alpha), \mathrm{Sb}_{2} \mathrm{~S}_{3}$ $(\mathrm{Sb} L \alpha)$, $\mathrm{Sn}(\mathrm{Sn} L \alpha), \mathrm{TI}(\mathrm{Br}, \mathrm{I})(\mathrm{TI} L \alpha)$ a ZnS $(\mathrm{ZnK \alpha})$. Pro xenotim, monazit a zirkon: urychlovací napětí $15 \mathrm{kV}$, proud elektronového svazku $10 \mathrm{nA}$, průměr svazku $1 \mu \mathrm{m}$; použité standardy a analytické čáry: albit ( $\mathrm{NaK \alpha}$ ), apatit $(\mathrm{P} K \alpha)$, baryt $(\mathrm{Ba} L \alpha), \mathrm{Bi}(\mathrm{Bi} M \alpha)$, $\mathrm{BN}(\mathrm{N} K \alpha)$, celestin $(\mathrm{S} K \alpha, \mathrm{Sr} L \beta)$, $\mathrm{CePO}_{4}(\mathrm{Ce} L \alpha), \mathrm{Cr}_{2} \mathrm{O}_{3}(\mathrm{Cr} K \alpha), \mathrm{Cs}-$ sklo (CsLa), diopsid (MgKa), DyPO $(\operatorname{Dy} L \beta), \mathrm{ErPO}_{4}(\mathrm{Er} L \alpha), \mathrm{EuPO}_{4}(\mathrm{EuL} \alpha)$, $\mathrm{GdPO}_{4}(\mathrm{Gd} L \alpha)$, halit $(\mathrm{Cl} K \alpha)$, hematit $(\mathrm{FeK} \alpha)$, $\mathrm{Hf}(\mathrm{HfM} \alpha), \mathrm{HoPO}_{4}(\mathrm{HoL} \beta)$, chalkopyrit ( $\mathrm{CuK \alpha}$ ), klinoklas (As $L \alpha)$, $\mathrm{LaPO}_{4}(\mathrm{LaL} \alpha), \quad \mathrm{LiF}(\mathrm{FK} \alpha), \mathrm{LuPO}_{4}$ $(\mathrm{LuM} \beta), \mathrm{NdPO}_{4}(\mathrm{Nd} L \beta), \mathrm{Ni}(\mathrm{NiK \alpha})$, $\mathrm{PrPO}_{4}(\operatorname{Pr} L \beta)$, Rb-Ge-sklo $(\mathrm{Rb} L \alpha)$, rodonit $(\mathrm{MnK} \alpha)$, sanidin $(\mathrm{K} K \alpha, \mathrm{Al} K \alpha)$, $\mathrm{ScVO}_{4} \quad(\mathrm{ScK} \alpha), \quad \mathrm{SmPO}_{4} \quad(\mathrm{SmL} \alpha)$, $\mathrm{TbPO}_{4} \quad(\mathrm{~Tb} L \alpha)$, Th $(\mathrm{Th} M \alpha), \mathrm{TiO}_{2}$ $(\mathrm{TiK} \alpha), \mathrm{TmPO}_{4}(\mathrm{Tm} L \alpha), \mathrm{UO}_{2}(\mathrm{UM} \alpha), \mathrm{V}$ $(\mathrm{VK \alpha})$, vanadinit $(\mathrm{PbM} \alpha)$, wollastonit $(\mathrm{CaK} \alpha), \mathrm{YbPO}_{4}(\mathrm{Yb} L \alpha), \mathrm{YVO}_{4}(\mathrm{Y} L \alpha)$, zirkon (SiKa, ZrLa). Pro supergenni minerální fáze: $15 \mathrm{kV}$, proud elektronového svazku $5 \mathrm{nA}$, průměr svazku 5 - $10 \mu \mathrm{m}$; albit (NaKa), baryt $(\mathrm{Ba} L \beta), \mathrm{Bi}(\mathrm{Bi} M \alpha), \mathrm{BN}(\mathrm{N} K \alpha)$, celestin $(\mathrm{S} K \alpha, \mathrm{SrL} \beta)$, chalkopyrit $(\mathrm{CuK \alpha})$, Co (CoKa), $\mathrm{Cr}_{2} \mathrm{O}_{3}(\mathrm{Cr} K \alpha)$, fluorapatit $(\mathrm{PK} \alpha)$, halit $(\mathrm{Cl} K \alpha)$, hematit $(\mathrm{Fe} K \alpha)$, klinoklas (AsLa), LiF (FKa), Ni (NiKa), rodonit $(\mathrm{MnK} \alpha)$, sanidin (AlKa, SiKa, $\mathrm{KK} \alpha)$, Th $(\mathrm{Th} M \alpha), \quad \mathrm{UO}_{2}(\mathrm{U} M \alpha), \mathrm{V}$ $(\mathrm{VK} \alpha)$, vanadinit $(\mathrm{PbM} \alpha)$, wollastonit $(\mathrm{CaK} \alpha)$ a $\mathrm{ZnO}(\mathrm{ZnK \alpha})$. Obsahy výše uvedených prvků, které nejsou zahrnuty $v$ tabulkách, byly kvantitativně analyzovány, ale zjištěné obsahy byly pod detekčním limitem (většinou cca $0.03-0.1 \mathrm{hm}$. \% pro jednotlivé prvky, pro REE a Bi kolem $0.2-0.3 \mathrm{hm}$. $\%)$. Získaná data byla přepočítána na hm. \% oxidů za použití PAP algoritmu (Pouchou, Pichoir 1985) s automatickou korekcí na koincidence La vs. Dy, Eu vs. Dy, F vs. Ce, Bi vs. Ce a Th vs. U. Obsahy REE v monazitu a xenotimu byly normalizovány na C1 chondrit s využitím chondritických hodnot podle Anderse a Grevesseho (1989). Výpočet $\mathrm{Ce}$, Eu a $\mathrm{Yb}$ anomálií byl proveden podle vztahů prezentovaných např. McLennanem (1989).

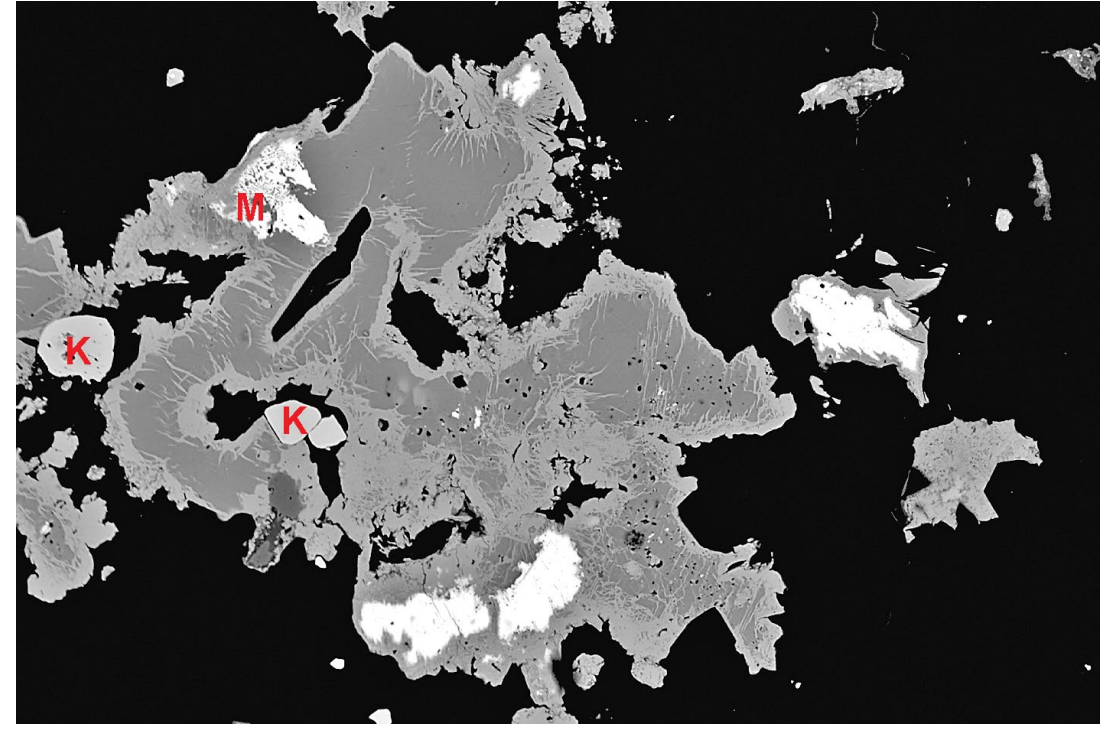

Obr. 9 Zrna emplektitu (bilý) a myrmekitu emplektit/chalkopyrit (označeno M) $v$ agregátech chalkopyritu (tmavě šedý) obrůstaných a zatlačovaných anilitem/digenitem (světle šedý), v asociaci se zrny kasiteritu (označeno K); Hřebečná; šiřka záběru 600 m, BSE foto J. Sejkora.

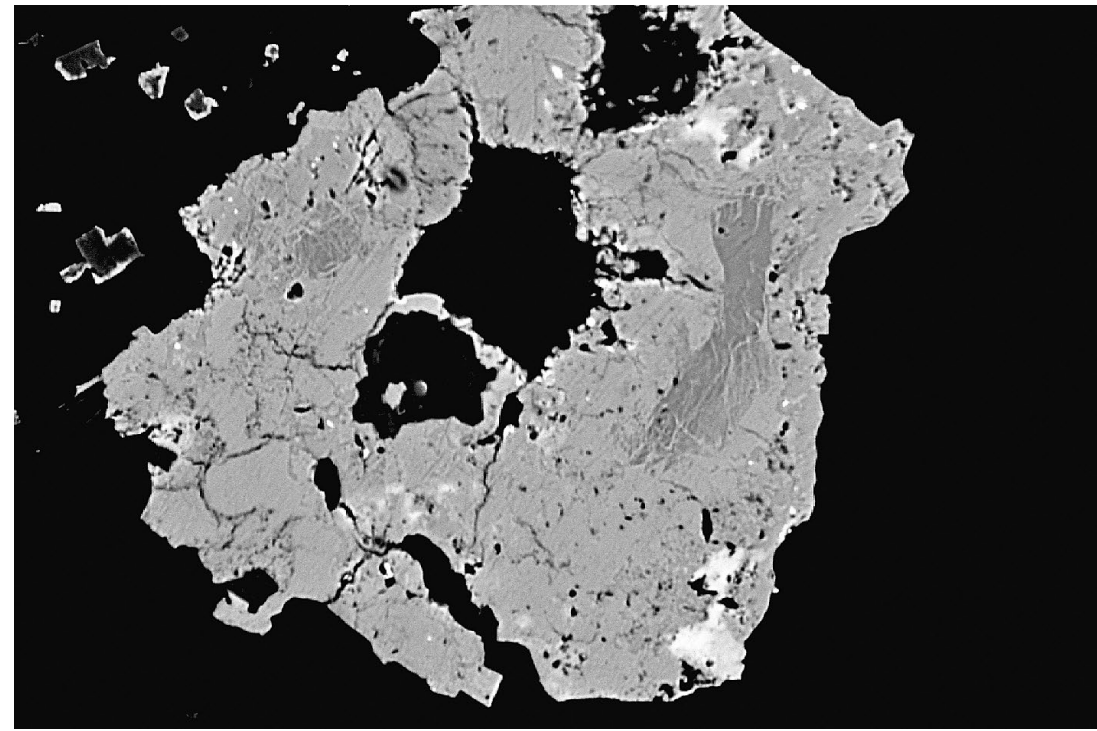

Obr. 10 Agregát anilitu (šedý) s relikty sfaleritu (tmavě šedý) a tennantitu-(Zn) (světle šedý); Hřebečná; šířka záběru 400 m, BSE foto Z. Dolníček.

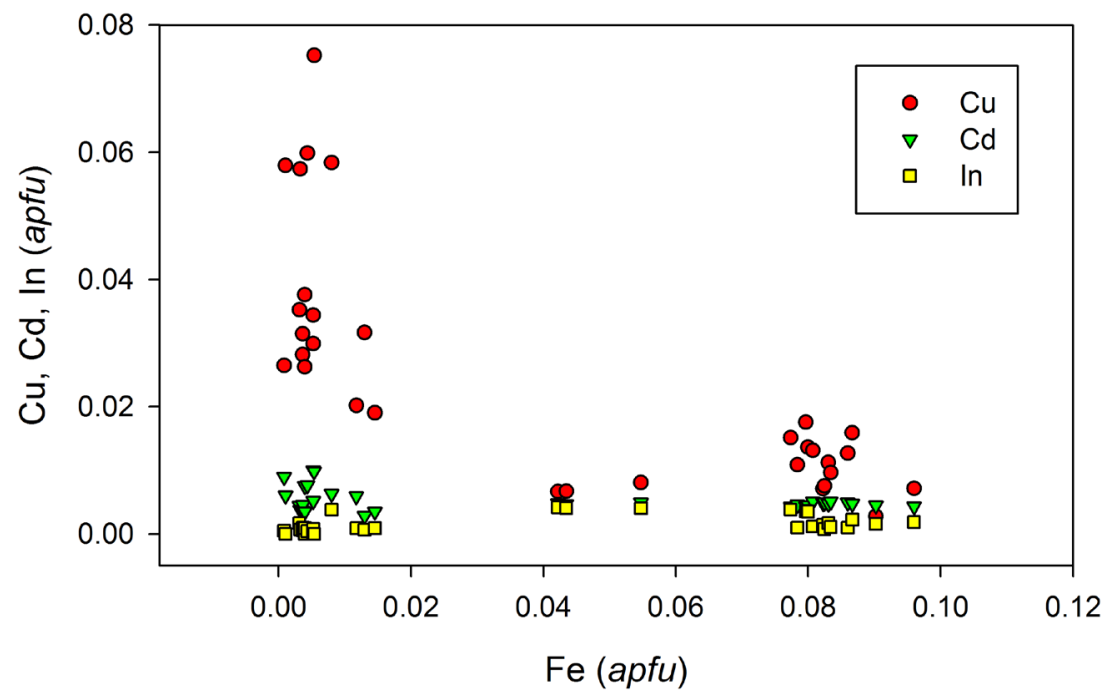

Obr. 11 Graf Fe vs. Cu, Cd, Zn (apfu) pro sfalerit z Hřebečné. 


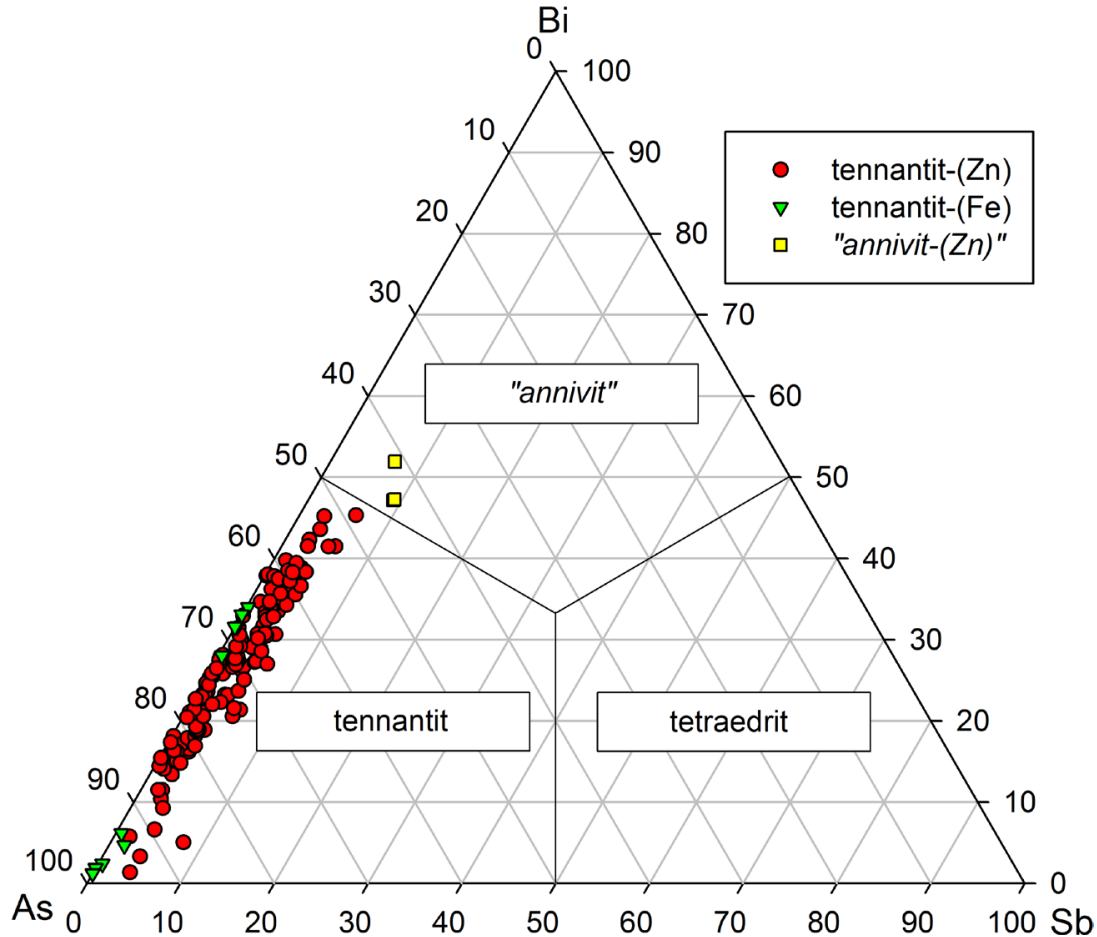

Obr. 12 Ternární graf Sb-Bi-As (at. jednotky) minerálů skupiny tetraedritu z Hřebečné.
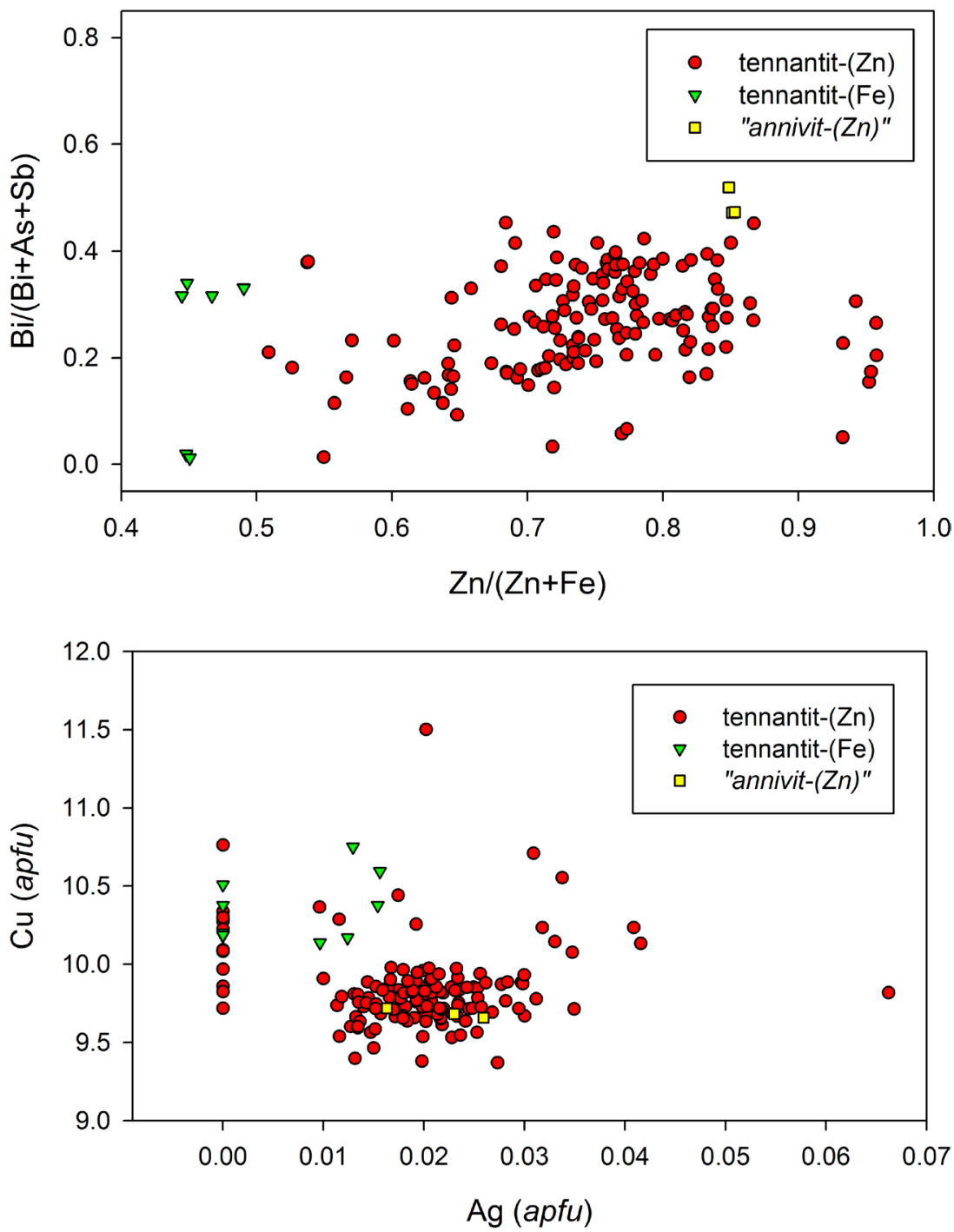

\section{Výsledky mineralogického vý- zkumu}

Nově studovaný materiál se od obvyklé jemnozrnné greisenové Snmineralizace dobývané $v$ oblasti dolu Mauritius výrazně odlišuje hrubozrnným charakterem křemenné žiloviny a častým výskytem zrn a krystalů fluorapatitu. Poprvé byl nalezen (MU) počátkem 80. let minulého století na starém odvalu u jámy dolu Mauritius. Obdobné vzorky pocházejí ze sběrů Jana Hlouška a novější vzorky z roku 2015 sbírali další spoluautoři této práce (MU, PP). V současně době jsou možnosti nálezů popisované mineralizace vlivem následných stavebních úprav v okolí dolu Mauritius minimální (obr. 6).

Studovaný materiál je představován křemennou žilovinou (křemenným greisenem), která obsahuje až několik $\mathrm{cm}$ velké drúzové dutiny s drobnými krystaly křemene. Charakteristická je hojná prítomnost více či méně navětralých zrn a nedokonale hexagonálně omezených, až několik $\mathrm{cm}$ velkých krystalů fluorapatitu. Lokálně byla v žilovině zjištěna nehojná sulfidická mineralizace, velikost agregátů sulfidů obvykle nepřevyšuje několik mm. Vlivem zvětrávacích procesů je $v$ části křemenné žiloviny fluorapatit výrazně korodován až zcela vyloužen; na vzniklé dutiny a drobné trhliny je vázán výskyt supergenní mineralizace. Předběžná informace o některých zjištěných minerálech byla podána $v$ popularizačním příspěvku Pauliše et al. (2015).

\section{Charakteristika sulfidické mi- neralizace}

Arsenopyrit vystupuje jako místy bohaté impregnace tvořené zrny o velikosti do $100 \mu \mathrm{m}$, které jsou někdy tmelené mladším pyritem (obr. 7). Jeho chemického složení (obr. 8) je charakteristické výrazným ochuzením As, zjištěný rozsah AsS substi- $_{-1}$ tuce (1.04 - 1.20 apfu S) je dokonce mírně širší než pro tento minerál

Obr. 13 Graf poměrů $Z n /(Z n+F e)$ vs. $\mathrm{Bi} /(B i+A s+S b)$ (at. jednotky) minerálů skupiny tetraedritu z Hřebečné.

Obr. 14 Graf Ag vs. Cu (apfu) minerálů skupiny tetraedritu z Hřebečné. 
Tabulka 5 Chemické složení tennantitu-(Fe) a „annivitu-(Zn)“z Hřebečné (hm. \%)

\begin{tabular}{lrrrrrrrrrrrrrr}
\hline & \multicolumn{10}{c}{} & \multicolumn{1}{c}{ tennantit-(Fe) } \\
\hline & 1 & 2 & 3 & 4 & 5 & 6 & 7 & 8 & 9 & 10 & 11 & 12 & 13 \\
\hline $\mathrm{Ag}$ & 0.00 & 0.00 & 0.09 & 0.07 & 0.00 & 0.00 & 0.10 & 0.00 & 0.08 & 0.10 & 0.16 & 0.10 & 0.14 \\
$\mathrm{Fe}$ & 3.54 & 3.64 & 4.25 & 3.86 & 3.72 & 2.91 & 2.85 & 3.31 & 2.52 & 3.18 & 1.03 & 1.00 & 1.02 \\
$\mathrm{Cd}$ & 0.00 & 0.00 & 0.06 & 0.06 & 0.00 & 0.00 & 0.32 & 0.40 & 0.25 & 0.22 & 0.00 & 0.00 & 0.00 \\
$\mathrm{Zn}$ & 3.40 & 3.45 & 3.15 & 3.55 & 3.40 & 2.62 & 2.92 & 3.10 & 2.85 & 3.03 & 6.90 & 6.80 & 6.70 \\
$\mathrm{Cu}$ & 43.65 & 43.73 & 42.99 & 42.72 & 43.14 & 40.69 & 40.76 & 39.63 & 41.15 & 39.70 & 35.09 & 35.07 & 34.69 \\
$\mathrm{Sb}$ & 0.00 & 0.00 & 0.15 & 0.55 & 0.19 & 0.12 & 0.00 & 0.08 & 0.00 & 0.07 & 2.43 & 2.45 & 1.81 \\
$\mathrm{Bi}$ & 0.67 & 1.04 & 1.33 & 2.60 & 3.25 & 13.97 & 15.10 & 15.58 & 15.59 & 16.64 & 21.65 & 21.60 & 23.36 \\
$\mathrm{As}$ & 19.05 & 18.98 & 19.23 & 18.62 & 17.62 & 12.79 & 11.72 & 12.02 & 11.31 & 11.55 & 7.19 & 7.13 & 6.64 \\
$\mathrm{~S}$ & 28.72 & 28.70 & 27.66 & 27.60 & 28.23 & 25.53 & 25.21 & 24.81 & 25.07 & 25.02 & 24.40 & 24.16 & 24.11 \\
\hline total & 99.03 & 99.54 & 98.91 & 99.63 & 99.56 & 98.62 & 98.97 & 98.93 & 98.83 & 99.51 & 98.85 & 98.31 & 98.47 \\
\hline $\mathrm{Ag}$ & 0.000 & 0.000 & 0.012 & 0.010 & 0.000 & 0.000 & 0.016 & 0.000 & 0.013 & 0.015 & 0.026 & 0.016 & 0.023 \\
$\mathrm{Fe}$ & 0.941 & 0.963 & 1.145 & 1.041 & 1.002 & 0.854 & 0.841 & 0.986 & 0.750 & 0.947 & 0.323 & 0.315 & 0.324 \\
$\mathrm{Cd}$ & 0.000 & 0.000 & 0.008 & 0.008 & 0.000 & 0.000 & 0.047 & 0.059 & 0.037 & 0.033 & 0.000 & 0.000 & 0.000 \\
$\mathrm{Zn}$ & 0.771 & 0.782 & 0.725 & 0.818 & 0.781 & 0.658 & 0.737 & 0.789 & 0.723 & 0.770 & 1.846 & 1.832 & 1.818 \\
$\mathrm{Cu}$ & 10.187 & 10.183 & 10.170 & 10.138 & 10.200 & 10.508 & 10.594 & 10.375 & 10.750 & 10.377 & 9.657 & 9.718 & 9.682 \\
$\mathrm{Sb}$ & 0.000 & 0.000 & 0.019 & 0.068 & 0.024 & 0.016 & 0.000 & 0.010 & 0.000 & 0.009 & 0.349 & 0.354 & 0.264 \\
$\mathrm{Bi}$ & 0.048 & 0.073 & 0.096 & 0.187 & 0.234 & 1.097 & 1.193 & 1.240 & 1.239 & 1.323 & 1.812 & 1.820 & 1.982 \\
$\mathrm{As}$ & 3.771 & 3.750 & 3.859 & 3.748 & 3.534 & 2.802 & 2.584 & 2.670 & 2.507 & 2.562 & 1.678 & 1.676 & 1.572 \\
$\mathrm{~S}$ & 13.283 & 13.248 & 12.968 & 12.981 & 13.227 & 13.065 & 12.988 & 12.870 & 12.981 & 12.965 & 13.309 & 13.268 & 13.336 \\
\hline $1-10$ & analýzy tennantitu-(Fe), $11-13$ analýzy „annivitu-(Zn)“; koeficienty empirických vzorců počítány na bázi 29 apfu. \\
\hline
\end{tabular}

Tabulka 6 Chemické složení digenitu a anilitu z Hřebečné (hm. \%)

\begin{tabular}{|c|c|c|c|c|c|c|c|c|c|c|c|c|c|c|}
\hline & \multicolumn{6}{|c|}{ digenit } & \multicolumn{8}{|c|}{ anilit } \\
\hline & 1 & 2 & 3 & 4 & 5 & 6 & 7 & 8 & 9 & 10 & 11 & 12 & 13 & 14 \\
\hline$\overline{A g}$ & 0.09 & 0.09 & 0.17 & 0.11 & 0.14 & 0.25 & 0.18 & 0.17 & 0.17 & 0.19 & 0.09 & 0.12 & 0.15 & 0.17 \\
\hline $\mathrm{Fe}$ & 0.25 & 1.25 & 0.00 & 0.31 & 0.07 & 0.07 & 0.07 & 0.86 & 0.52 & 0.71 & 0.85 & 1.11 & 0.08 & 0.88 \\
\hline $\mathrm{Cu}$ & 78.98 & 78.06 & 77.45 & 77.89 & 77.64 & 77.07 & 77.92 & 76.21 & 76.45 & 76.65 & 76.60 & 77.39 & 77.95 & 76.54 \\
\hline$\underline{S}$ & 22.85 & 22.88 & 22.17 & 22.25 & 22.07 & 21.86 & 21.93 & 23.22 & 22.86 & 22.98 & 22.91 & 23.08 & 22.82 & 22.60 \\
\hline total & 102.17 & 102.27 & 99.79 & 100.56 & 99.91 & 99.25 & 100.11 & 100.46 & 100.00 & 100.53 & 100.45 & 101.69 & 101.00 & 100.19 \\
\hline $\mathrm{Ag}$ & 0.006 & 0.006 & 0.012 & 0.007 & 0.009 & 0.017 & 0.012 & 0.009 & 0.009 & 0.010 & 0.005 & 0.006 & 0.008 & 0.009 \\
\hline $\mathrm{Fe}$ & 0.032 & 0.159 & 0.000 & 0.040 & 0.009 & 0.009 & 0.010 & 0.087 & 0.053 & 0.072 & 0.086 & 0.112 & 0.008 & 0.090 \\
\hline $\mathrm{Cu}$ & 8.874 & 8.752 & 8.926 & 8.909 & 8.944 & 8.945 & 8.973 & 6.799 & 6.868 & 6.849 & 6.849 & 6.840 & 6.951 & 6.877 \\
\hline$S$ & 5.088 & 5.083 & 5.063 & 5.043 & 5.038 & 5.029 & 5.005 & 4.105 & 4.070 & 4.069 & 4.060 & 4.042 & 4.033 & 4.024 \\
\hline $\mathrm{Me} / \mathrm{S}$ & 1.75 & 1.75 & 1.77 & 1.78 & 1.78 & 1.78 & 1.80 & 1.68 & 1.70 & 1.70 & 1.71 & 1.72 & 1.73 & 1.73 \\
\hline
\end{tabular}

Tabulka 7 Chemické složení minerálů známých v systému Cu-S

\begin{tabular}{|c|c|c|c|c|c|c|c|c|}
\hline \multirow[b]{3}{*}{ chalkozín } & \multirow{3}{*}{$\begin{array}{l}\text { vzorec } \\
\mathrm{Cu}_{2} \mathrm{~S}\end{array}$} & \multicolumn{3}{|c|}{ poměr Me/S } & \multicolumn{4}{|c|}{ at. $\%$ kovu } \\
\hline & & \multirow{2}{*}{$\begin{array}{c}\text { ideal } \\
2.00\end{array}$} & \multicolumn{2}{|r|}{ rozmezí $^{*}$} & \multirow{2}{*}{$\begin{array}{r}\text { ideal } \\
66.67\end{array}$} & \multicolumn{3}{|c|}{ rozmezí $^{*}$} \\
\hline & & & 1.96 & -2.04 & & 66.22 & - & 67.11 \\
\hline djurleit & $\mathrm{Cu}_{31} \mathrm{~S}_{16}$ & 1.94 & 1.87 & $\begin{array}{l}-\quad 1.97\end{array}$ & 65.99 & 65.16 & - & 66.33 \\
\hline digenit/roxbyit & $\mathrm{Cu}_{9} \mathrm{~S}_{5}$ & 1.80 & 1.75 & - 1.83 & 64.29 & 63.64 & - & 64.80 \\
\hline anilit & $\mathrm{Cu}_{7} \mathrm{~S}_{4}$ & 1.75 & 1.69 & - $\quad 1.77$ & 63.64 & 62.83 & - & 63.90 \\
\hline geerit & $\mathrm{Cu}_{8} \mathrm{~S}_{5}$ & 1.60 & 1.44 & - 1.62 & 61.54 & 59.02 & - & 61.83 \\
\hline spionkopit & $\mathrm{Cu}_{39} \mathrm{~S}_{28}$ & 1.39 & 1.21 & - 1.44 & 58.16 & 54.75 & - & 58.68 \\
\hline yarrowit & $\mathrm{Cu}_{9} \mathrm{~S}_{8}$ & 1.13 & 1.06 & - 1.19 & 53.05 & 51.51 & - & 54.34 \\
\hline covellín & Cus & 1.00 & 0.97 & - $\quad 1.19$ & 50.00 & 49.24 & - & 54.34 \\
\hline
\end{tabular}

rozmezí ${ }^{\star}$ - rozmezí hodnot pozorovaných v prírodních vzorcích podle prací Morimoto, Kato (1970); Goble, Robinson (1980); Grønvold, Westrum (1980); Goble (1980 a 1981); Anthony et al. (1990); Gablina et al. (2000); Hatert (2005); Okrusch et al. (2007); Litochleb et al. (2009); Škácha, Sejkora (2013) a Sejkora et al. (2016). 


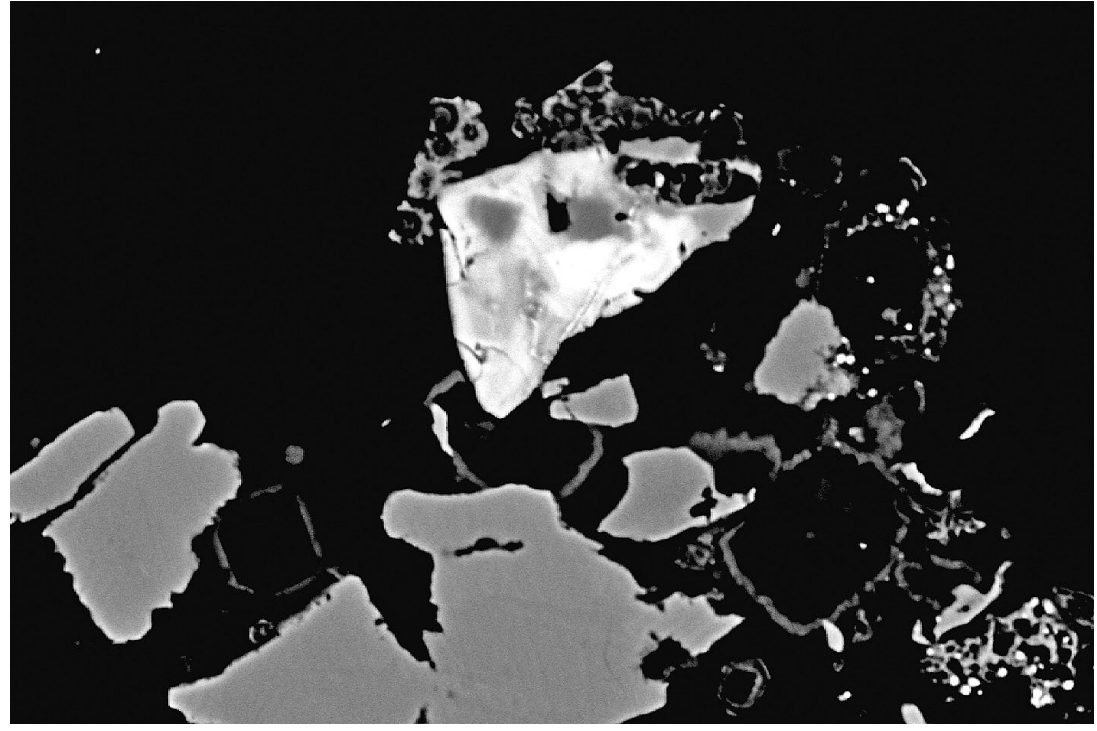

Obr. 15 Zóny „annivitu-(Zn)“ (bílé) v zonálním agregátu Bi-bohatého tennantitu -(Zn) v asociaci s arsenopyritem (šedý) a pyritem (černý); Hřebečná; šírka záběru $120 \mu \mathrm{m}$, BSE foto J. Sejkora.

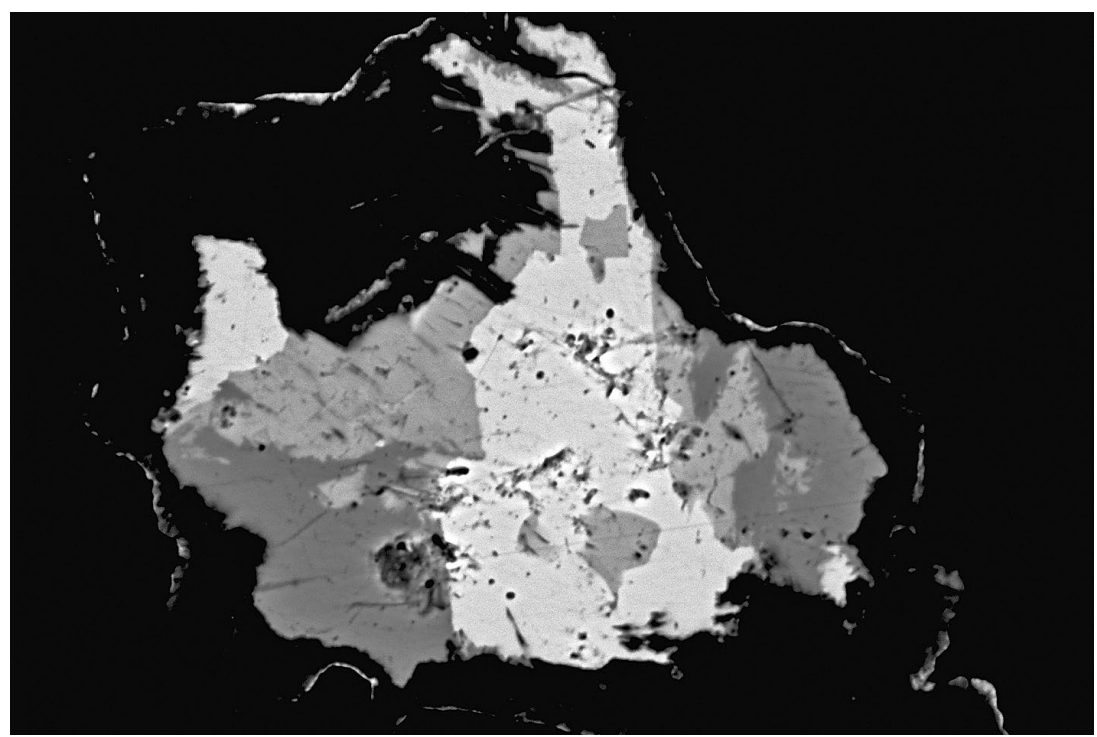

Obr. 16 Zrna aikinitu (bílý) srůstající s emplektitem (šedý) a wittichenitem (tmavě šedý) v agregátech geeritu (černý); Hřebečná; šiřka záběru 120 m, BSE foto J. Sejkora.

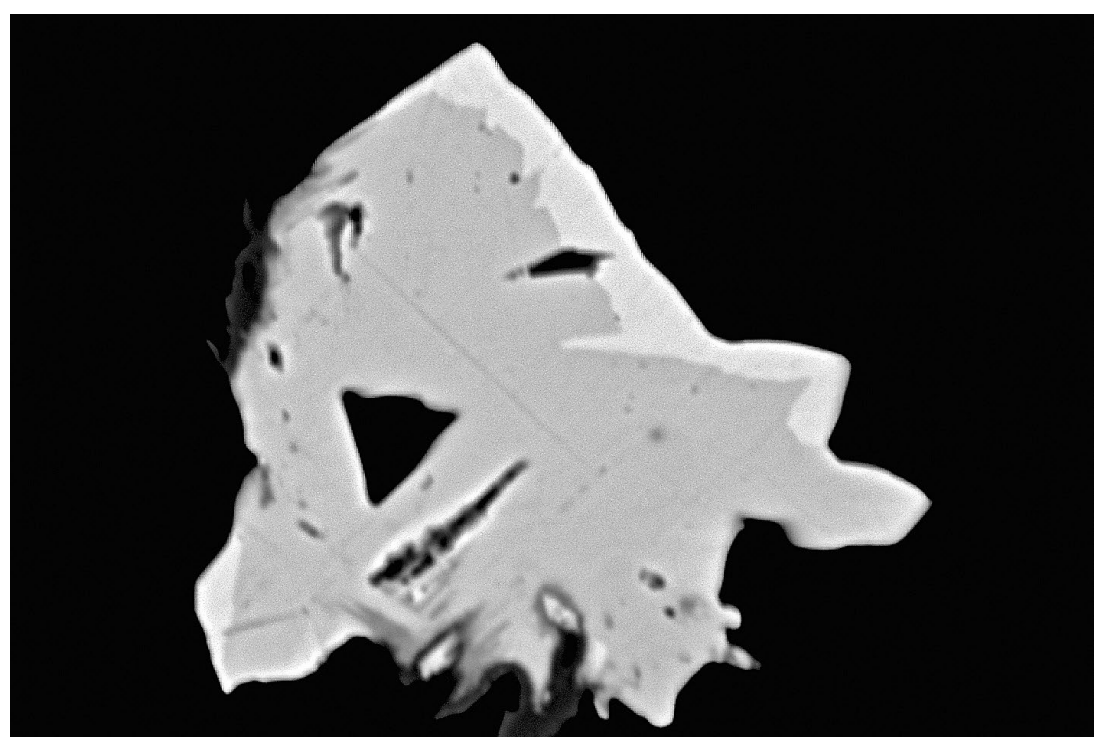

uvádějí Kretschmar, Scott (1976) a Sharp et al. (1985). Dále byly zjištěny minoritní obsahy Sb (do 0.02 apfu) a pro arsenopyrit neobvyklé minoritní zastoupení Cu (do 0.03 apfu). Reprezentativní chemické analýzy a koeficienty empirických vzorců na bázi 3 apfu jsou uvedeny v tabulce 1.

Chalkopyrit patří ve studovaných vzorcích k nejhojnějším sulfidům. Velikost jeho agregátů nepřevyšuje několik mm, obvykle je od okrajů agregátu intenzívně zatlačovaný anilitem/ digenitem (obr. 9). Jeho chemické složení odpovídá ideálnímu vzorci tohoto minerálu, nebyly $v$ něm zjištěny obsahy žádných minoritních prvků (tab. 2). Průměrný (sedm bodových analýz) empirický vzorec chalkopyritu je možno na bázi 4 apfu vyjádřit jako $\mathrm{Cu}_{1.01} \mathrm{Fe}_{0.99} \mathrm{~S}_{2.00}$.

Pyrit se obvykle vyskytuje jen jako nehojné drobné (do $50 \mu \mathrm{m}$ ) idiomorfní krystaly a zrna, lokálně tmelí starší zrna arsenopyritu (obr. 7). Při studiu jeho chemického složení byly vedle $\mathrm{Fe}$ a $S$ zjištěny pouze minoritní príměsi $\mathrm{Cu}$ (do $0.10 \mathrm{apfu}$ ), As (do $0.05 \mathrm{apfu}$ ) a Pb (do $0.002 \mathrm{apfu}$ ); obsahy těchto prvků spolu navzájem nekorelují. Reprezentativní chemické analýzy a koeficienty empirických vzorců na bázi 3 apfu jsou uvedeny v tabulce 2.

Sfalerit je ve studovaných vzorcích relativně hojnější (srovnatelně s chalkopyritem). Vyskytuje se jako agregáty o velikosti do $200 \mu \mathrm{m}$, při okrajích v různém rozsahu zatlačované anilitem/digenitem. Pozorovány byly také relikty sfaleritu $\mathrm{v}$ agregátech anilitu (obr. 10). Podle obsahu minoritních prvků je možno rozlišit dva základní typy sfaleritu (obr. 11), prvním typem je relativně Fe-chudý (do 0.015 apfu) sfalerit s obsahy Cd (do $0.010 \mathrm{apfu}$ ), In (do $0.004 \mathrm{apfu}$ ) a vyšším obsahem Cu (do 0.075 apfu). Druhým typem je Fe-bohatší (0.08 $0.10 \mathrm{apfu}$ ) sfalerit s obsahy $\mathrm{Cd}$ (do $0.005 \mathrm{apfu}$ ), In (do $0.004 \mathrm{apfu}$ ) a nižším zastoupením Cu (0.003- 0.018 apfu). Reprezentativní chemické analýzy a koeficienty empirických vzorců na bázi 2 apfu jsou uvedeny v tabulce 3

Obr. 17 Lem aikinitu (bílý) kolem agregátu cuprobismutitu (šedý); Hřebečná; šírka záběru $80 \mu \mathrm{m}$, BSE foto J. Sejkora. 
Tabulka 8 Chemické složení geeritu, spionkopitu a covellínu z Hřebečné (hm. \%)

\begin{tabular}{|c|c|c|c|c|c|c|c|c|c|c|c|c|c|c|}
\hline \multicolumn{5}{|c|}{ geerit } & \multicolumn{7}{|c|}{ spionkopit } & \multicolumn{3}{|c|}{ covellín } \\
\hline & 1 & 2 & 3 & 4 & 5 & 6 & 7 & 8 & 9 & 10 & 11 & 12 & 13 & 14 \\
\hline $\mathrm{Ag}$ & 0.45 & 0.06 & 0.47 & 0.40 & 0.14 & 0.51 & 0.16 & 0.33 & 0.40 & 0.49 & 0.68 & 0.55 & 0.23 & 0.40 \\
\hline $\mathrm{Fe}$ & 0.00 & 1.34 & 0.00 & 0.55 & 0.93 & 1.35 & 0.27 & .11 & 1.31 & 1.21 & 0.85 & .15 & 1.34 & 1.86 \\
\hline $\mathrm{Pb}$ & 0.19 & 0.00 & 0.18 & 0.00 & 0.00 & 0.00 & 0.00 & 0.00 & 0.00 & 0.00 & 0.00 & 0.00 & 0.00 & 0.00 \\
\hline $\mathrm{Cu}$ & 72.78 & 73.63 & 73.18 & 74.92 & 72.24 & 72.33 & 73.30 & 71.77 & 71.70 & 71.01 & 70.24 & 71.15 & 61.86 & 61.16 \\
\hline $\mathrm{Bi}$ & 2.16 & 0.00 & 2.76 & 0.00 & 0.00 & 0.00 & 0.00 & 0.00 & 0.00 & 0.00 & 0.00 & 0.00 & 0.00 & 0.00 \\
\hline As & 0.00 & 0.00 & 0.00 & 0.00 & 0.00 & 0.00 & 0.00 & 0.00 & 0.00 & 0.00 & .00 & .00 & .45 & 0.97 \\
\hline $\mathrm{Se}$ & 0.08 & 0.00 & 0.11 & 0.00 & 0.00 & 0.00 & 0.00 & 0.00 & 0.00 & 0.00 & 0.00 & 0.00 & 0.00 & 0.00 \\
\hline$S$ & 22.27 & 23.63 & 22.73 & 24.18 & 25.91 & 26.56 & 26.52 & 26.56 & 27.11 & 27.69 & 27.49 & 28.02 & 30.86 & 31.41 \\
\hline total & 97.93 & 98.66 & 99.42 & 100.05 & 99.22 & 100.75 & 100.25 & 99.77 & 100.52 & 100.40 & 99.26 & 100.87 & 94.74 & 95.80 \\
\hline $\mathrm{Ag}$ & 0.029 & 0.004 & 0.030 & 0.025 & 0.044 & 0.159 & 0.050 & 0.103 & 0.124 & 0.152 & 0.213 & 169 & 0.002 & 0.004 \\
\hline $\mathrm{Fe}$ & 0.000 & 0.162 & 0.000 & 0.066 & 0.568 & 0.812 & 0.163 & 0.672 & 0.785 & 0.723 & 0.514 & 0.683 & 0.024 & 0.033 \\
\hline $\mathrm{Pb}$ & 0.006 & 0.000 & 0.006 & 0.000 & 0.000 & 0.000 & 0.000 & 0.000 & 0.000 & 0.000 & 0.000 & 0.000 & 0.000 & 0.000 \\
\hline $\mathrm{Cu}$ & 8.021 & 7.844 & 7.962 & 7.873 & 38.804 & 38.217 & 38.897 & 38.204 & 37.780 & 37.300 & 37.324 & 37.151 & 0.989 & 0.966 \\
\hline $\mathrm{Bi}$ & 0.072 & 0.000 & 0.091 & 0.000 & 0.000 & 0.000 & 0.000 & 0.000 & 0.000 & 0.000 & 0.000 & 0.000 & 0.000 & 0.000 \\
\hline As & 0.000 & 0.000 & 0.000 & 0.000 & 0.000 & 0.000 & 0.000 & 0.000 & 0.000 & 0.000 & 0.000 & 0.000 & 0.006 & 0.013 \\
\hline $\mathrm{Se}$ & 0.007 & 0.000 & 0.009 & 0.000 & 0.000 & 0.000 & 0.000 & 0.000 & 0.000 & 0.000 & 0.000 & 0.000 & 0.000 & 0.000 \\
\hline$\underline{S}$ & 4.864 & 4.989 & 4.901 & 5.036 & 27.583 & 27.812 & 27.890 & 28.020 & 28.310 & 28.826 & 28.950 & 28.996 & 0.978 & 0.984 \\
\hline $\mathrm{Me} / \mathrm{S}$ & 1.63 & 1.61 & 1.60 & 1.58 & 1.43 & 1.41 & 1.40 & 1.39 & 1.37 & 1.32 & 1.31 & 1.31 & 1.03 & 1.01 \\
\hline
\end{tabular}

Tabulka 9 Chemické složení aikinitu z Hřebečné (hm. \%)

\begin{tabular}{lrrrrrr}
\hline & mean & 1 & 2 & 3 & 4 & 5 \\
\hline $\mathrm{Ag}$ & 0.11 & 0.00 & 0.00 & 0.00 & 0.12 & 0.41 \\
$\mathrm{~Pb}$ & 34.12 & 30.48 & 34.76 & 34.86 & 34.93 & 35.58 \\
$\mathrm{Cu}$ & 11.30 & 9.52 & 11.34 & 11.62 & 12.06 & 11.95 \\
$\mathrm{Bi}$ & 38.71 & 43.69 & 38.20 & 37.71 & 37.12 & 36.83 \\
$\mathrm{~S}$ & 17.20 & 17.47 & 17.12 & 17.11 & 17.36 & 16.95 \\
\hline total & 101.43 & 101.16 & 101.42 & 101.29 & 101.60 & 101.71 \\
\hline $\mathrm{Ag}$ & 0.006 & 0.000 & 0.000 & 0.000 & 0.006 & 0.021 \\
$\mathrm{~Pb}$ & 0.928 & 0.840 & 0.947 & 0.948 & 0.938 & 0.964 \\
$\mathrm{Cu}$ & 1.001 & 0.855 & 1.007 & 1.030 & 1.056 & 1.056 \\
$\mathrm{Bi}$ & 1.043 & 1.194 & 1.032 & 1.016 & 0.988 & 0.990 \\
$\mathrm{~S}$ & 3.022 & 3.111 & 3.014 & 3.006 & 3.012 & 2.968 \\
\hline $\mathrm{n}_{\text {aik }}$ & 96.1 & 83.0 & 97.3 & 98.6 & 100.4 & 101.0 \\
\hline$\Delta \mathrm{n}_{\text {aik }}$ & -3.7 & -0.8 & -3.0 & -4.1 & -6.0 & -4.6 \\
\hline
\end{tabular}

mean - průměr z pěti bodových analýz; koeficienty empirických vzorců počítány na bázi 6 apfu.

Tabulka 10 Chemické složení bismutinitu z Hřebečné (hm. \%)

\begin{tabular}{lrrrrrrrrrrrrrr}
\hline & mean & 1 & 2 & 3 & 4 & 5 & 6 & 7 & 8 & 9 & 10 & 11 & 12 & 13 \\
\hline $\mathrm{Ag}$ & 0.07 & 0.00 & 0.38 & 0.35 & 0.00 & 0.00 & 0.00 & 0.00 & 0.00 & 0.00 & 0.00 & 0.00 & 0.00 & 0.16 \\
$\mathrm{~Pb}$ & 2.01 & 3.19 & 3.33 & 2.62 & 4.33 & 2.83 & 2.04 & 2.04 & 2.16 & 0.82 & 0.73 & 1.02 & 0.23 & 0.84 \\
$\mathrm{Cu}$ & 0.85 & 1.18 & 1.41 & 0.85 & 1.42 & 1.02 & 0.69 & 0.70 & 0.69 & 1.00 & 1.02 & 0.33 & 0.42 & 0.38 \\
$\mathrm{Sb}$ & 0.05 & 0.08 & 0.00 & 0.00 & 0.00 & 0.00 & 0.15 & 0.00 & 0.15 & 0.00 & 0.00 & 0.10 & 0.09 & 0.11 \\
$\mathrm{Bi}$ & 77.17 & 75.20 & 75.29 & 75.80 & 75.87 & 76.12 & 76.65 & 76.85 & 76.97 & 78.06 & 78.56 & 78.81 & 79.27 & 79.82 \\
$\mathrm{Se}$ & 0.08 & 0.09 & 0.11 & 0.22 & 0.13 & 0.08 & 0.06 & 0.23 & 0.09 & 0.00 & 0.07 & 0.00 & 0.00 & 0.00 \\
$\mathrm{~S}$ & 19.00 & 18.94 & 18.54 & 18.65 & 19.37 & 19.03 & 18.82 & 18.89 & 18.79 & 19.00 & 19.11 & 19.36 & 18.97 & 19.54 \\
\hline total & 99.25 & 98.68 & 99.06 & 98.49 & 101.12 & 99.08 & 98.41 & 98.71 & 98.85 & 98.88 & 99.49 & 99.62 & 98.98 & 100.85 \\
\hline $\mathrm{Ag}$ & 0.003 & 0.000 & 0.018 & 0.017 & 0.000 & 0.000 & 0.000 & 0.000 & 0.000 & 0.000 & 0.000 & 0.000 & 0.000 & 0.007 \\
$\mathrm{~Pb}$ & 0.049 & 0.078 & 0.082 & 0.065 & 0.103 & 0.069 & 0.050 & 0.050 & 0.053 & 0.020 & 0.018 & 0.025 & 0.006 & 0.020 \\
$\mathrm{Cu}$ & 0.068 & 0.094 & 0.113 & 0.068 & 0.110 & 0.081 & 0.056 & 0.056 & 0.056 & 0.080 & 0.081 & 0.026 & 0.034 & 0.030 \\
$\mathrm{Sb}$ & 0.002 & 0.003 & 0.000 & 0.000 & 0.000 & 0.000 & 0.006 & 0.000 & 0.006 & 0.000 & 0.000 & 0.004 & 0.004 & 0.005 \\
$\mathrm{Bi}$ & 1.870 & 1.824 & 1.835 & 1.857 & 1.794 & 1.842 & 1.878 & 1.875 & 1.883 & 1.895 & 1.894 & 1.901 & 1.936 & 1.903 \\
$\mathrm{Se}$ & 0.005 & 0.006 & 0.007 & 0.014 & 0.008 & 0.005 & 0.004 & 0.015 & 0.006 & 0.000 & 0.004 & 0.000 & 0.000 & 0.000 \\
$\mathrm{~S}$ & 3.001 & 2.994 & 2.945 & 2.978 & 2.985 & 3.002 & 3.006 & 3.004 & 2.996 & 3.006 & 3.003 & 3.044 & 3.020 & 3.036 \\
\hline $\mathrm{n}_{\text {aik }}$ & 6.1 & 9.0 & 10.1 & 6.9 & 11.2 & 7.8 & 5.5 & 5.5 & 5.6 & 5.1 & 5.1 & 2.6 & 2.0 & 2.6 \\
\hline$\Delta \mathrm{n}_{\text {aik }}$ & -1.0 & -0.8 & -1.6 & -0.2 & -0.4 & -0.6 & -0.3 & -0.3 & -0.1 & -3.1 & -3.2 & -0.1 & -1.4 & -0.5 \\
\hline mean - průmmerr z 13 bodových analýz; koeficienty & empirických vzorců počítány na bázi 5 apfu. & &
\end{tabular}

mean - průměr z 13 bodových analýz; koeficienty empirických vzorců počítány na bázi 5 apfu. 


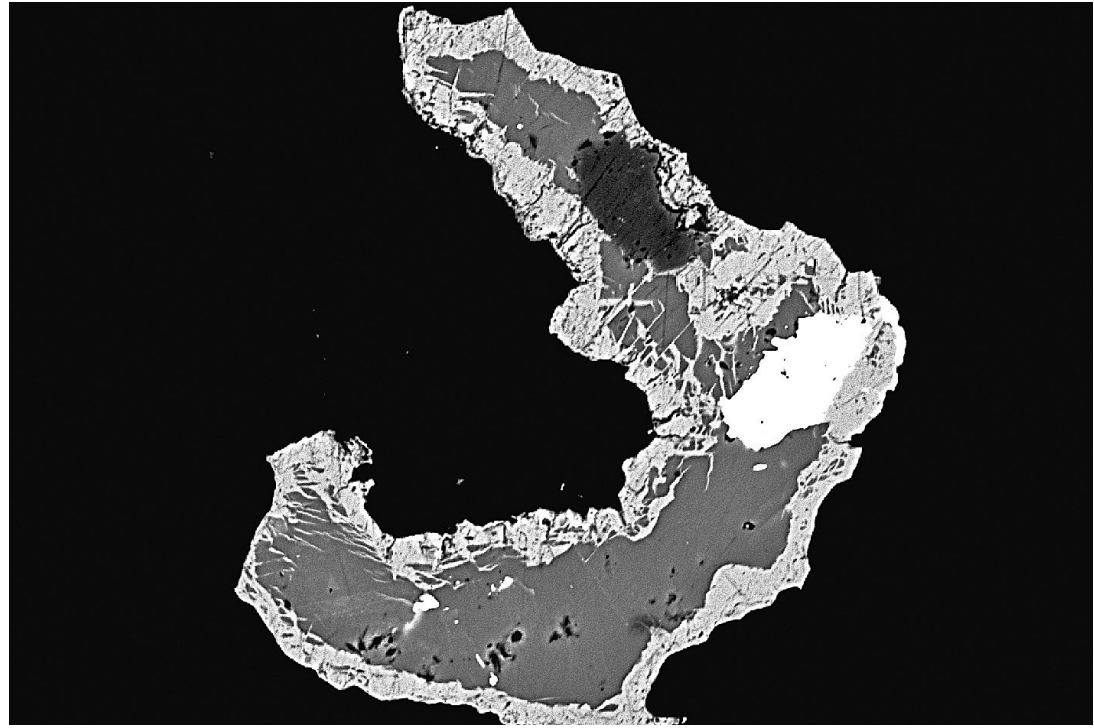

Obr. 18 Protáhlé zrno berryitu (bílý) v agregátu chalkopyritu (tmavě šedý) zatlačovaném anilitem (světle šedý); Hřebečná; šiřka záběru $220 \mu \mathrm{m}$, BSE foto J. Sejkora.

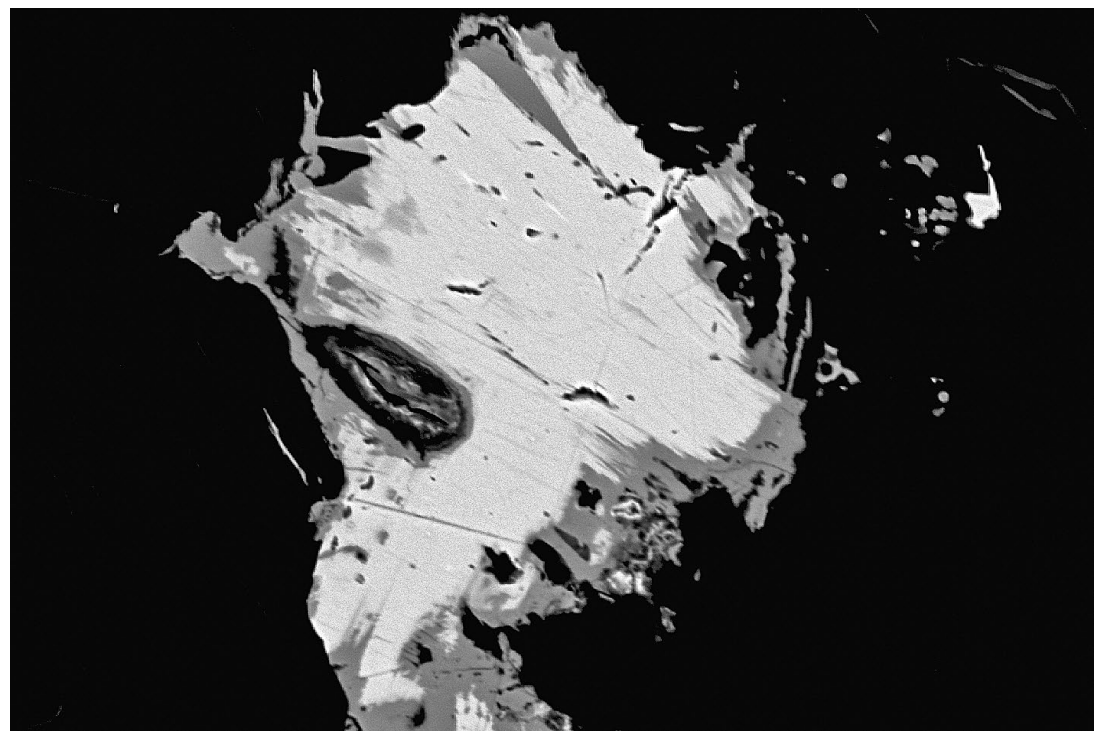

Obr. 19 Agregát cuprobismutitu (bílý) zatlačovaný wittichenitem (tmavě šedý); Hřebečná; šířka záběru 160 m, BSE foto J. Sejkora.

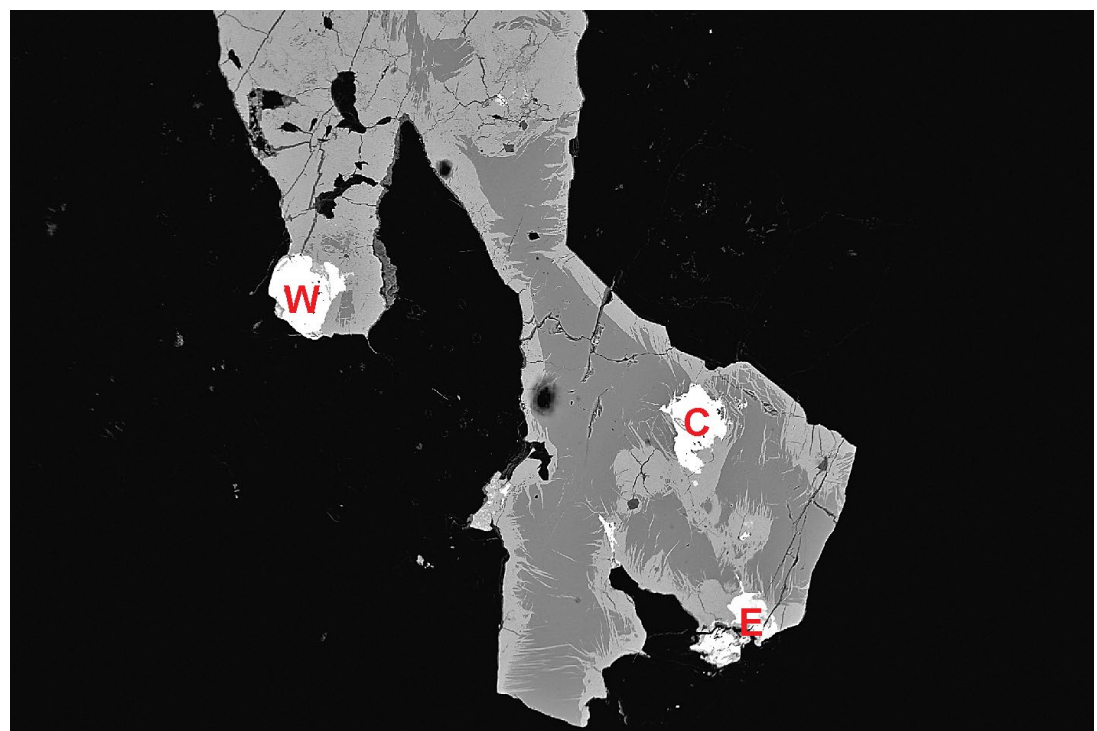

Minerály skupiny tetraedritu vytvářejí nehojná zrna a agregáty o velikosti do $200 \mu \mathrm{m} v$ křemenné žilovině, obvykle $v$ asociaci $s$ chalkopyritem, pyritem, arsenopyritem a sfaleritem. Zcela převažujícím minerálem ze skupiny tetraedritu je ve studovaném materiálu tennantit-(Zn) s širokým rozsahem As - Bi izomorfie (obr. 12) a jen malými obsahy Sb (do 0.29 apfu); zjištěné obsahy Bi se pohybují v rozmezí 0.05 - 1.70 apfu. Dominantní Zn (0.83 - 2.01 apfu) je doprovázen obsahy $\mathrm{Fe} v$ rozmezí 0.07 - 1.08 apfu (obr. 13). Výrazně vzácněji byl zjištěn tennantit-(Fe) s obsahy Fe 0.75 - 1.14 apfu jen mírně převažujícími nad Zn (0.65 - 0.82 apfu) a také výrazným zastoupením Bi v trigonálně pyramidální pozici (do 1.32 apfu). Obsahy Ag (obr. 14) jsou ve všech studovaných zrnech nízké (obvykle do 0.04, v jednom bodě do 0.07 apfu) a nekorelují s obsahy $\mathrm{Bi}$ nebo poměrem Zn/Fe. Reprezentativní chemické analýzy a koeficienty empirických vzorců na bázi 29 apfu jsou uvedeny v tabulkách 4 a 5 .

$V$ některých agregátech Bi-bohatého tennantitu-(Zn) byly pozorovány protáhlé až nepravidelné zóny o velikosti do $20 \mu \mathrm{m}$ (obr. 15), které svým chemickým složením (tab. 5) již odpovídají dosud nedefinovanému Bidominantnímu členu skupiny tetraedritu; v následujícím textu pro ně pro zjednodušení používáme označení „annivit-(Zn)“ s tím, že se v současné době nejedná o platné jméno minerálu (annivit byl diskreditován $v$ rámci nové klasifikace minerálů skupiny tetraedritu, Biagioni et al. 2020). $\checkmark$ trigonálně pyramidální pozici obecného vzorce „annivitu-(Zn)“ (obr. 12) převládá Bi s obsahy 1.81 - 1.99 apfu nad As (1.57 - 1.68) a Sb (0.26 - 0.35 apfu). V trigonální pozici byly vedle převládající Cu (obr. 14) zjištěny minoritní obsahy Ag do 0.03 apfu; v tetraedrické pozici vždy převládá Zn s obsahy 1.82 - 1.85 apfu (obr. 13) nad Fe (0.32 apfu).

Výskyty minerálů skupiny tetraedritu, ve kterých je Bi převládajícím prvkem $v$ trigonálně pyramidální pozici, jsou dosud uváděny pouze z pěti

Obr. 20 Agregát chalkopyritu (tmavě šedý) zatlačovaný anilitem/ digenitem (světleji šedý) se zrny cuprobismutitu (C), emplektitu (E) a wittichenitu (W); Hřebečná; širrka záběru $1400 \mu m$, BSE foto J. Sejkora. 
lokalit - z Pb-Zn rud na lokalitě Vindfall (2.64 apfu Bi) ve Švédsku (Kieft, Eriksson 1984), z ložiska Tary-Ekan (1.63 apfu) v centrální Asii (Bortnikov et al. 1986), z ložiska Tyrnyauz (1.60 apfu) v Rusku (Spiridonov et al. 1986), z lokality Rędziny (2.65 apfu) v Polsku (Gołębiowska et al. 2012) a z rudního revíru Jáchymov (1.89 apfu Bi) v Krušných horách (Velebil, Sejkora 2018). Pro žádný z těchto známých výskytů se však nepodařilo získat strukturní data a tak tento člen dosud nebyl popsán jako platný minerální druh (Gołębiowska et al. 2012; Biagioni et al. 2020). Pokusy syntetizovat Bi-dominantní analog tetraedritu a tennantitu nebyly dosud úspěšné; Klünder et al. (2003) uvádějí obsahy Bi v synteticky připravených tetraedritech a tennantitech do 0.8 apfu prí $350{ }^{\circ} \mathrm{C}$ a do 1 apfu při 450 a $520^{\circ} \mathrm{C}$.

Anilit a digenit jsou nejhojnější $z$ jednoduchých $\mathrm{Cu}$ sulfidů identifikovaných na lokalitě. Ve vzájemných srůstech vytvářejí agregáty o velikosti do $1 \mathrm{~mm}$, které charakteristicky od okrajů zrn zatlačují chalkopyrit (obr. 9) nebo sfalerit (obr. 10). Chemické složení digenitu (tab. 6) s 63.9 (63.7 - 64.3) at. \% kovů odpovídá hodnotám uváděným pro přírodní digenit a roxbyit (tab. 7); od roxbyitu (Mumme et al. 1988) se studovaný minerál zřetelně odlišuje optickými vlastnostmi. Z minoritních prvků byly ve studovaném digenitu zjištěny obsahy Fe (do 0.16 apfu) a Ag (do 0.02 apfu). Jeho empirický vzorec (průměr 18 analýz) je možno na bázi 14 apfu vyjádřit jako $\left(\mathrm{Cu}_{8.92} \mathrm{Fe}_{0.03} \mathrm{Ag}_{0.01}\right)_{\Sigma 8.96} \mathrm{~S}_{5.04}$. Chemické analýzy anilitu (tab. 6) s 63.1 (62.7 - 63.4) at. \% kovů odpovídají rozmezí uváděnému pro tuto minerální fázi (tab. 7); z minoritních prvků bylo zjištěno zastoupení $\mathrm{Fe}$ (do $0.11 \mathrm{apfu}$ ) a $\mathrm{Ag}$ (do $0.01 \mathrm{apfu}$ ). Průměrný (16 bodových analýz) empirický vzorec (na bázi 11 apfu je $\left(\mathrm{Cu}_{6.89}\right.$ $\left.\mathrm{Fe}_{0.05} \mathrm{Ag}_{0.01}\right)_{\Sigma 6.95} \mathrm{~S}_{4.05}$.

Tabulka 11 Chemické složení berryitu z Hřebečné (hm. \%)

\begin{tabular}{|c|c|c|c|c|c|c|c|}
\hline & mean & 1 & 2 & 3 & 4 & 5 & 6 \\
\hline $\mathrm{Ag}$ & 6.85 & 5.69 & 6.32 & 7.07 & 7.19 & 7.24 & 7.56 \\
\hline $\mathrm{Fe}$ & 0.30 & 0.28 & 0.38 & 0.15 & 0.41 & 0.35 & 0.23 \\
\hline $\mathrm{Pb}$ & 20.66 & 20.81 & 20.87 & 20.30 & 20.85 & 20.29 & 20.81 \\
\hline $\mathrm{Cu}$ & 7.80 & 9.59 & 9.25 & 6.65 & 7.30 & 6.92 & 7.09 \\
\hline $\mathrm{Bi}$ & 47.84 & 47.64 & 46.85 & 48.49 & 48.52 & 47.21 & 48.33 \\
\hline $\mathrm{Se}$ & 0.16 & 0.07 & 0.19 & 0.07 & 0.17 & 0.21 & 0.22 \\
\hline$S$ & 17.23 & 17.77 & 17.21 & 17.02 & 17.15 & 16.84 & 17.38 \\
\hline total & 100.82 & 101.85 & 101.07 & 99.75 & 101.59 & 99.06 & 101.62 \\
\hline $\mathrm{Ag}$ & 1.857 & 1.497 & 1.690 & 1.964 & 1.952 & 2.012 & 2.045 \\
\hline $\mathrm{Fe}$ & 0.157 & 0.141 & 0.195 & 0.080 & 0.215 & 0.188 & 0.120 \\
\hline $\mathrm{Pb}$ & 2.917 & 2.852 & 2.905 & 2.936 & 2.947 & 2.936 & 2.931 \\
\hline $\mathrm{Cu}$ & 3.591 & 4.282 & 4.198 & 3.136 & 3.364 & 3.265 & 3.256 \\
\hline $\mathrm{Bi}$ & 6.698 & 6.471 & 6.465 & 6.953 & 6.798 & 6.773 & 6.749 \\
\hline $\mathrm{Se}$ & 0.058 & 0.026 & 0.070 & 0.027 & 0.063 & 0.080 & 0.081 \\
\hline $\mathrm{S}$ & 15.722 & 15.731 & 15.477 & 15.905 & 15.662 & 15.746 & 15.818 \\
\hline
\end{tabular}

Tabulka 12 Chemické složení cuprobismutitu z Hřebečné (hm. \%)

\begin{tabular}{lrrrrrrrrrrrr}
\hline & mean & 1 & 2 & 3 & 4 & 5 & 6 & 7 & 8 & 9 & 10 & 11 \\
\hline $\mathrm{Ag}$ & 4.47 & 4.12 & 4.23 & 4.21 & 4.11 & 4.75 & 4.03 & 4.28 & 4.96 & 4.94 & 4.95 & 4.56 \\
$\mathrm{~Pb}$ & 0.45 & 0.62 & 0.69 & 0.59 & 0.69 & 0.12 & 0.61 & 0.63 & 0.27 & 0.00 & 0.14 & 0.61 \\
$\mathrm{Cu}$ & 12.72 & 13.16 & 13.19 & 13.13 & 12.91 & 12.79 & 12.81 & 12.78 & 12.71 & 12.64 & 12.37 & 11.43 \\
$\mathrm{Bi}$ & 64.08 & 64.39 & 64.27 & 64.24 & 64.29 & 63.21 & 64.62 & 63.99 & 63.71 & 64.45 & 64.19 & 63.58 \\
$\mathrm{Se}$ & 0.07 & 0.15 & 0.00 & 0.10 & 0.18 & 0.00 & 0.17 & 0.13 & 0.00 & 0.00 & 0.00 & 0.00 \\
$\mathrm{~S}$ & 19.06 & 19.09 & 19.18 & 18.99 & 19.05 & 18.89 & 19.01 & 18.97 & 19.08 & 19.26 & 19.13 & 19.04 \\
\hline total & 100.85 & 101.53 & 101.57 & 101.26 & 101.21 & 99.76 & 101.24 & 100.76 & 100.73 & 101.29 & 100.78 & 99.22 \\
\hline $\mathrm{Ag}$ & 1.662 & 1.522 & 1.561 & 1.562 & 1.524 & 1.781 & 1.498 & 1.597 & 1.844 & 1.826 & 1.844 & 1.731 \\
$\mathrm{~Pb}$ & 0.087 & 0.120 & 0.132 & 0.114 & 0.133 & 0.023 & 0.118 & 0.122 & 0.052 & 0.000 & 0.027 & 0.121 \\
$\mathrm{Cu}$ & 8.036 & 8.258 & 8.261 & 8.271 & 8.134 & 8.139 & 8.088 & 8.092 & 8.020 & 7.930 & 7.820 & 7.367 \\
$\mathrm{Bi}$ & 12.312 & 12.283 & 12.240 & 12.303 & 12.322 & 12.232 & 12.410 & 12.321 & 12.224 & 12.296 & 12.340 & 12.461 \\
$\mathrm{Se}$ & 0.034 & 0.076 & 0.000 & 0.053 & 0.089 & 0.000 & 0.088 & 0.066 & 0.000 & 0.000 & 0.000 & 0.000 \\
$\mathrm{~S}$ & 23.869 & 23.740 & 23.806 & 23.698 & 23.798 & 23.825 & 23.799 & 23.802 & 23.860 & 23.948 & 23.969 & 24.321 \\
\hline$N_{\text {chem }}$ & 2.00 & 1.87 & 1.87 & 1.88 & 1.94 & 1.95 & 1.97 & 1.97 & 2.02 & 2.06 & 2.13 & 2.39 \\
\hline mean - průměr z 11 bodových analýz; koeficienty empirických vzorců počítány na bázi 46 apfu. & &
\end{tabular}

Tabulka 13 Chemické složení emplektitu z Hřebečné (hm. \%)

\begin{tabular}{|c|c|c|c|c|c|c|c|c|c|c|c|c|}
\hline & mean & 1 & 2 & 3 & 4 & 5 & 6 & 7 & 8 & 9 & 10 & 11 \\
\hline$\overline{\mathrm{Cu}}$ & 19.86 & 19.96 & 21.64 & 19.66 & 21.03 & 19.80 & 19.55 & 19.33 & 19.30 & 19.53 & 19.68 & $\overline{19.46}$ \\
\hline $\mathrm{Sb}$ & 0.06 & 0.00 & 0.09 & 0.00 & 0.00 & 0.00 & 0.15 & 0.11 & 0.00 & 0.06 & 0.16 & 0.17 \\
\hline $\mathrm{Bi}$ & 60.77 & 59.66 & 59.92 & 59.93 & 60.28 & 60.36 & 60.46 & 60.55 & 60.64 & 60.91 & 61.00 & 61.12 \\
\hline S & 19.81 & 19.65 & 18.68 & 19.63 & 18.62 & 19.71 & 19.86 & 19.81 & 19.90 & 19.89 & 19.91 & 20.17 \\
\hline total & 100.51 & 99.27 & 100.33 & 99.22 & 99.93 & 99.87 & 100.02 & 99.80 & 99.84 & 100.39 & 100.75 & 100.92 \\
\hline $\mathrm{Cu}$ & 1.024 & 1.036 & 1.125 & 1.024 & 1.103 & 1.026 & 1.011 & 1.003 & 1.000 & 1.008 & 1.012 & 0.997 \\
\hline $\mathrm{Sb}$ & 0.002 & 0.000 & 0.002 & 0.000 & 0.000 & 0.000 & 0.004 & 0.003 & 0.000 & 0.002 & 0.004 & 0.005 \\
\hline $\mathrm{Bi}$ & 0.952 & 0.942 & 0.947 & 0.949 & 0.961 & 0.951 & 0.950 & 0.956 & 0.956 & 0.956 & 0.954 & 0.952 \\
\hline & 2.023 & 2.022 & 1.925 & 2.027 & 1.935 & 2.024 & 2.035 & 2.038 & 2.044 & 2.034 & 2.029 & 2.047 \\
\hline
\end{tabular}

mean - průměr z 19 bodových analýz; 1-11 reprezentativní analýzy; koeficienty empirických vzorců počítány na bázi 4 apfu. 
Geerit byl zjištěn jen vzácně jako agregáty o velikosti do $50 \mu \mathrm{m}$, které obrůstají aikinit, emplektit a wittichenit. Bodové chemické analýzy s 61.6 (61.3 - 61.9) at. \% kovů odpovídají publikovaným hodnotám (tab. 7). Zjištěny byly minoritní obsahy (tab. 8) Fe (do 0.16 apfu), Bi (do 0.09 apfu), Ag (do 0.03 apfu), Pb (do 0.01 apfu) a Se (do 0.01 apfu). Empirický vzorec geeritu z Hřebečné je možno na bázi 13 apfu (průměr 4 analýz) vyjádřit jako $\left(\mathrm{Cu}_{7.93} \mathrm{Fe}_{0.06} \mathrm{Ag}_{0.02}\right)_{\Sigma 8.01} \mathrm{Bi}_{0.04} \mathrm{~S}_{4.95}$.

Spionkopit byl určen ve formě několika agregátů o velikosti do $100 \mu \mathrm{m}$ intenzívně zatlačujících starší sfalerit, lokálně i v asociaci s anilitem. Pro jeho chemické složení (tab. 8) je charakteristický obsah kovů v rozmezí 56.7 až 58.7 (průměr 57.7 ) at. \%, který je $v$ souladu $s$ daty publikovanými pro tento minerální druh (tab. 7). Vedle převažující $\mathrm{Cu}$ a $\mathrm{S}$ byly zjištěny minoritní nepravidelné obsahy $\mathrm{Fe}$ do 0.81 apfu a $\mathrm{Ag}$ do 0.22 apfu. Prüměrné složení (14 bodových analýz) spionkopitu z Hřebečné je možno na bázi 57 apfu vyjádřit empirickým vzorcem $\left(\mathrm{Cu}_{37.92} \mathrm{Fe}_{0.59} \mathrm{Ag}_{0.12}\right)_{\Sigma 38.63} \mathrm{~S}_{28.36}$.

Covellín byl zjištěn jen ojediněle jako nevelké (do 20 $\mu \mathrm{m})$ agregáty $\mathrm{v}$ asociaci $\mathrm{s}$ anilitem/digenitem. Jeho chemické analýzy s 50.2 - 50.8 at. \% kovů (tab. 8) se bliží ideální stechiometrii CuS jen s minoritními obsahy Fe (do
$0.03 \mathrm{apfu}$ ), As (do $0.01 \mathrm{apfu}$ ) a Ag (do $0.003 \mathrm{apfu}$ ). Empirický vzorec (průměr dvou analýz) je možno na bázi 2 apfu vyjádřit jako $\left(\mathrm{Cu}_{0.98} \mathrm{Fe}_{0.03}\right)_{\Sigma 1.01}\left(\mathrm{~S}_{0.98} \mathrm{As}_{0.01}\right)_{\Sigma 0.99}$.

Aikinit tvoří vzácná protáhlá zrna o velikosti do 50 $\mu \mathrm{m}$ srůstající s wittichenitem a emplektitem a zarůstající do geeritu (obr. 16) nebo tenké lemy (do $10 \mu \mathrm{m}$ ) na zrnech cuprobismutitu (obr. 17). Prri studiu jeho chemického složení (tab. 9) byly vedle $\mathrm{Cu}, \mathrm{Pb}, \mathrm{Bi}$ a $\mathrm{S}$ zjištěny pouze minoritní příměsi Ag (do 0.02 apfu); procenta aikinitové komponenty $\mathrm{n}_{\text {aik }}$ (vypočtené podle Makovicky, Makovicky 1978) jsou v rozmezí 83 - 101, což dobře odpovídá údajům uváděným pro tento minerální druh (Topa et al. 2002). Průměrný (pět bodových analýz) empirický vzorec aikinitu z Hřebečné na bázi 6 apfu je $\mathrm{Pb}_{0.93} \mathrm{Cu}_{1.00} \mathrm{Bi}_{1.04} \mathrm{~S}_{3.02}$.

Bismutinit je ve studovaném materiálu vzácný. $\vee$ křemenné žilovině tvoří zrna o velikosti do 20 - 50 um, která jsou místy zatlačovaná emplektitem. Chemické složení (tab. 10) odpovídá stechiometrii bismutinitu s rozsahem aikinitové substituce 2 - $11 \% \mathrm{n}_{\text {aik }}$ (Makovicky, Makovicky 1978), lokálně byly zjištěny i minoritní obsahy $\mathrm{Ag}$ (do $0.02 \mathrm{apfu}$ ), Sb a Se (do 0.01 apfu). Průměrný (13 bodových analýz) empirický vzorec bismutinitu z Hřebečné je možno na bázi 5 apfu vyjádřit jako $\mathrm{Bi}_{1.87} \mathrm{~Pb}_{0.05} \mathrm{Cu}_{0.07}\left(\mathrm{~S}_{3.00}\right.$ $\left.\mathrm{Se}_{0.01}\right)_{\Sigma 3.01}$.

Tabulka 14 Chemické složení wittichenitu z Hřebečné (hm. \%)

\begin{tabular}{|c|c|c|c|c|c|c|c|c|c|c|c|c|c|c|}
\hline & mean & 1 & 2 & 3 & 4 & 5 & 6 & 7 & 8 & 9 & 10 & 11 & 12 & 13 \\
\hline$\overline{A g}$ & 0.14 & 0.07 & 0.10 & 0.10 & 0.10 & 0.10 & 0.11 & 0.11 & 0.16 & 0.18 & 0.19 & 0.24 & 0.26 & 0.29 \\
\hline $\mathrm{Cu}$ & 39.15 & 38.93 & 39.60 & 39.13 & 37.23 & 38.86 & 39.08 & 39.02 & 38.75 & 39.20 & 38.89 & 9.91 & 8.95 & 8.98 \\
\hline $\mathrm{Bi}$ & 42.05 & 42.35 & 42.21 & 42.24 & 44.71 & 42.50 & 42.36 & 42.39 & 41.49 & 41.70 & 41.41 & 40.62 & 41.19 & 41.97 \\
\hline $\mathrm{Se}$ & 0.03 & 0.09 & 0.00 & 0.05 & 0.08 & 0.00 & 0.04 & 0.00 & 0.06 & 0.10 & 0.00 & 0.00 & 0.04 & 0.04 \\
\hline$S$ & 19.71 & 19.81 & 19.73 & 19.40 & 18.96 & 19.73 & 19.72 & 19.84 & 19.67 & 19.71 & 19.75 & 20.05 & 20.01 & 19.83 \\
\hline total & 101.07 & 101.25 & 101.65 & 100.92 & 101.07 & 101.18 & 101.31 & 101.35 & 100.14 & 100.88 & 100.24 & 100.82 & 100.44 & 101.11 \\
\hline$\overline{\mathrm{Ag}}$ & 006 & 0.003 & 004 & 0.004 & 05 & 04 & 05 & 0.005 & 0.007 & 0.008 & 0.009 & 0.011 & 0.012 & 0.013 \\
\hline $\mathrm{Cu}$ & 3.008 & 2.989 & 3.026 & 3.026 & 2.944 & 2.991 & 3.001 & 2.992 & 2.998 & 3.011 & 3.001 & 3.032 & 2.986 & 2.990 \\
\hline $\mathrm{Bi}$ & 982 & 0.989 & 981 & 0.993 & 1.075 & .995 & 0.989 & 0.988 & 0.976 & 0.974 & 0.971 & 0.938 & 0.960 & 0.979 \\
\hline $\mathrm{Se}$ & 0.002 & 0.005 & 0.000 & 0.003 & 0.005 & 0.000 & 0.003 & 0.000 & 0.004 & 0.006 & 0.000 & 0.000 & 0.003 & 0.002 \\
\hline$c$ & 3.001 & 3.014 & 2.988 & 2.973 & 2.971 & 3.010 & 3.002 & 3.015 & 3.016 & 3.000 & 3.019 & 3.019 & 3.040 & 3.015 \\
\hline
\end{tabular}

mean - průměr ze 17 bodových analýz; 1-13 reprezentativní analýzy; koeficienty empirických vzorců počítány na bázi 7 apfu.

Tabulka 15 Chemické složení fluorapatitu z Hřebečné (hm. \%)

\begin{tabular}{|c|c|c|c|c|c|c|c|c|c|c|c|c|c|c|}
\hline & 1 & 2 & 3 & 4 & 5 & 6 & 7 & 8 & 9 & 10 & 11 & 12 & 13 & 14 \\
\hline$\overline{\mathrm{CaO}}$ & 54.31 & 54.45 & 54.75 & 55.25 & 54.37 & 53.79 & 54.09 & 53.62 & 54.92 & 53.78 & 54.40 & 54.26 & 53.50 & 53.79 \\
\hline $\mathrm{FeO}$ & 0.74 & 0.40 & 0.60 & 0.45 & 0.74 & 0.00 & 0.00 & 0.00 & 0.00 & 0.00 & 0.00 & 0.00 & 0.00 & 0.00 \\
\hline SrO & 0.00 & 0.00 & 0.00 & 0.00 & 0.00 & 0.91 & 0.76 & 0.99 & 0.00 & 0.00 & 0.39 & 0.00 & 0.00 & 0.00 \\
\hline $\mathrm{MgO}$ & 0.00 & 0.00 & 0.00 & 0.00 & 0.00 & 0.38 & 0.30 & 0.41 & 0.00 & 0.34 & 0.33 & 0.42 & 0.00 & 0.00 \\
\hline $\mathrm{MnO}$ & 0.87 & 1.13 & 1.33 & 0.44 & 1.52 & 0.42 & 0.30 & 0.44 & 0.44 & 1.54 & 0.84 & 0.46 & 1.79 & 1.12 \\
\hline $\mathrm{Al}_{2} \mathrm{O}_{3}$ & 0.00 & 0.00 & 0.00 & 0.00 & 0.00 & 0.00 & 0.00 & 0.00 & 0.14 & 0.00 & 0.41 & 0.36 & 0.71 & 0.61 \\
\hline $\mathrm{As}_{2} \mathrm{O}_{5}$ & 0.00 & 0.00 & 0.00 & 0.00 & 0.00 & 0.00 & 0.00 & 0.42 & 0.00 & 0.00 & 1.98 & 0.00 & 0.00 & 0.00 \\
\hline $\mathrm{P}_{2} \mathrm{O}_{5}{ }^{5}$ & 41.54 & 42.16 & 40.09 & 40.73 & 40.71 & 43.51 & 42.75 & 43.91 & 41.59 & 42.01 & 41.58 & 41.36 & 41.67 & 41.94 \\
\hline & 3.80 & 4.03 & 3.33 & 3.77 & 3.44 & 4.54 & 4.10 & 3.91 & 4.69 & 4.19 & 4.24 & 4.07 & 4.19 & 4.01 \\
\hline $\mathrm{O}=\mathrm{F}$ & -1.60 & -1.70 & -1.40 & -1.59 & -1.45 & -1.91 & -1.73 & -1.65 & -1.97 & -1.76 & -1.79 & -1.71 & -1.76 & -1.69 \\
\hline total & 99.66 & 100.48 & 98.69 & 99.06 & 99.33 & 101.64 & 100.57 & 102.05 & 99.81 & 100.10 & 102.38 & 99.22 & 100.10 & 99.78 \\
\hline $\mathrm{Ca}$ & 4.963 & 4.904 & 5.185 & 5.150 & 5.070 & 4.694 & 4.804 & 4.609 & 5.014 & 4.860 & 4.825 & 4.981 & 4.875 & 4.869 \\
\hline $\mathrm{Fe}$ & 0.053 & 0.028 & 0.044 & 0.033 & 0.054 & 0.000 & 0.000 & 0.000 & 0.000 & 0.000 & 0.000 & 0.000 & 0.000 & 0.000 \\
\hline $\mathrm{Sr}$ & 0.000 & 0.000 & 0.000 & 0.000 & 0.000 & 0.043 & 0.037 & 0.046 & 0.000 & 0.000 & 0.019 & 0.000 & 0.000 & 0.000 \\
\hline $\mathrm{Mg}$ & 0.000 & 0.000 & 0.000 & 0.000 & 0.000 & 0.046 & 0.037 & 0.049 & 0.000 & 0.043 & 0.041 & 0.054 & 0.000 & 0.000 \\
\hline $\mathrm{Mn}$ & 0.063 & 0.080 & 0.099 & 0.033 & 0.112 & 0.029 & 0.021 & 0.030 & 0.032 & 0.110 & 0.059 & 0.033 & 0.129 & 0.080 \\
\hline $\mathrm{Al}$ & 0.000 & 0.000 & 0.000 & 0.000 & 0.000 & 0.000 & 0.000 & 0.000 & 0.014 & 0.000 & 0.040 & 0.036 & 0.071 & 0.061 \\
\hline As & 0.000 & 0.000 & 0.000 & 0.000 & 0.000 & 0.000 & 0.000 & 0.018 & 0.000 & 0.000 & 0.086 & 0.000 & 0.000 & 0.000 \\
\hline $\mathrm{P}$ & 3.000 & 3.000 & 3.000 & 3.000 & 3.000 & 3.000 & 3.000 & 2.982 & 3.000 & 3.000 & 2.914 & 3.000 & 3.000 & 3.000 \\
\hline$\underline{F}$ & 1.025 & 1.072 & 0.931 & 1.038 & 0.946 & 1.169 & 1.075 & 0.992 & 1.264 & 1.118 & 1.110 & 1.103 & 1.127 & 1.072 \\
\hline
\end{tabular}


Vzácný berryit byl zjištěn jako protáhlá zrna o velikosti do $50 \mu \mathrm{m} v$ agregátech chalkopyritu zatlačovaného anilitem (obr. 18) nebo agregáty o velikosti do $25 \mu \mathrm{m}$ srůstající $s$ chalkopyritem a tennantitem-(Zn). Původně uváděný ideální vzorec berryitu $\mathrm{Pb}_{3}(\mathrm{Ag}, \mathrm{Cu})_{5} \mathrm{Bi}_{7} \mathrm{~S}_{16}$ byl na základě studia jeho krystalové struktury zpřesněn jako $\mathrm{Cu}_{3} \mathrm{Ag}_{2} \mathrm{~Pb}_{3} \mathrm{Bi}_{7} \mathrm{~S}_{16}$ (Topa et al. 2006), ale i pro jeho novější publikované analýzy je charakteristický poměrně velký rozsah zjištěné nestechiometrie (Karup-Møller 1977; Cook 1998; Gu et al. 2001; Topa et al. 2006). Chemické složení studovaného berryitu z Hřebečné (tab. 11) také vykazuje poměrně velký rozptyl hodnot u jednotlivých prvků, ale až na dvě bodové analýzy s 4.20 a 4.28 apfu Cu (možná ovlivněné okolním prostředím), jsou hodnoty srovnatelné s publikovanými údaji (Topa et al. 2006) a nejvíce se blíži dvěma analýzám berryitu z lokality Funishan v Číně (Gu et al. 2001). Průměrné chemické složení berryitu z Hřebečné (šest bodových analýz) Ize vyjádřit na bázi 31 apfu empirickým vzorcem $\mathrm{Cu}_{3.59} \mathrm{Ag}_{1.86}$ $\mathrm{Fe}_{0.16} \mathrm{~Pb}_{2.92} \mathrm{Bi}_{6.70}\left(\mathrm{~S}_{15.75} \mathrm{Se}_{0.06}\right)_{\Sigma 15.78}$.

Cuprobismutit se vyskytuje jako alotriomorfní zrna o velikosti do 50 - $60 \mu \mathrm{m}$ obrůstané aikinitem (obr. 17), zarůstající do anilitu nebo zatlačovaná wittichenitem (obr. 19) v agregátech chalkopyritu, který je zatlačován anilitem/digenitem (obr. 20). Obecný vzorec minerálů cuprobismutitové homologické série může být vyjádřen jako $(\mathrm{Cu}, \mathrm{Fe})_{8}(\mathrm{Bi}, \mathrm{Sb}, \mathrm{Ag}, \mathrm{Pb}, \mathrm{Cd})_{10+4(\mathrm{~N}-1)}(\mathrm{S}, \mathrm{Se})_{4 \mathrm{~N}+16}$ (Topa et al. 2003a; Makovicky 2019); kde $N_{\text {chem }}$ ćíslo cuprobismutitového homologu je definováno vztahem $2\left(, \mathrm{Bi} / / \mathrm{Cu}^{\prime \prime}\right)-1.5$; ve kterém „Bi“ představuje součet $\mathrm{Bi}+\mathrm{Sb}+\mathrm{Ag}+\mathrm{Pb}+$ $\mathrm{Cd}+\mathrm{Zn}$, a "Cu" pak Cu + Fe (Topa et al. 2003a). Na této bázi, kupčíkit $\mathrm{S}$ ideálním vzorcem $\left(\mathrm{Cu}_{3.4} \mathrm{Fe}_{0.6}\right)_{\Sigma 4} \mathrm{Bi}_{5} \mathrm{~S}_{10}$ je homologem s $N_{\text {chem }}=1$, hodrušit $(\mathrm{Cu}, \mathrm{Fe})_{8}(\mathrm{Bi}, \mathrm{Ag})_{12} \mathrm{~S}_{22}$ má $N_{\text {chem }}=1.5$, a cuprobismutit se vzorcem $\mathrm{Cu}_{8}(\mathrm{Bi}, \mathrm{Ag})_{14} \mathrm{~S}_{24}$ je homologem s $N_{\text {chem }}=2$ (Topa et al. 2003a,b). Studovaný minerál z Hřebečné (tab. 12) s vypočtenými hodnotami $N_{c h e m} \vee$ rozmezí 1.87 - 2.39 odpovídá cuprobismutitu; absence $\mathrm{Fe}$ a vyšší minoritní obsahy $\mathrm{Ag}$ (3.3 - 4.0 at. \%) jsou pro tento minerální druh také charakteristické (Sejkora et al. 2015). Jeho průměrné chemické složení (11 bodových analýz) dává na bázi 46 apfu empirický vzorec $\mathrm{Cu}_{8.04}\left(\mathrm{Bi}_{12.31} \mathrm{Ag}_{1.66} \mathrm{~Pb}_{0.09}\right)_{\Sigma 14.06}\left(\mathrm{~S}_{23.87} \mathrm{Se}_{0.03}\right)_{\Sigma 23.90}$.

Emplektit tvoŕi protáhlá zrna o velikosti do $150 \mu \mathrm{m}$ $v$ agregátech chalkopyritu zatlačovaných anilitem/digenitem (obr. 9), vzácně byly pozorovány i jeho myrmekitové srůsty s chalkopyritem. Dále byl pozorován i jako zrna zatlačující bismutinit nebo srůstající s aikinitem a wittichenitem v geeritu (obr. 16). Chemické složení emplektitu (tab. 13) odpovídá ideálnímu vzorci $\mathrm{CuBiS}_{2}$, zjištěny byly jen lokální minoritní obsahy Sb nepřevyšující 0.01 apfu. Empirický vzorec (průměr 19 bodových analýz) je možno na bázi 4 apfu uvést jako $\mathrm{Cu}_{1.02} \mathrm{Bi}_{0.95} \mathrm{~S}_{2.02}$.

Wittichenit byl v křemenné žilovině zjištěn jako izometrická nepravidelná zrna o velikosti do $100 \mu \mathrm{m}$ v agregátech chalkopyritu intenzivně zatlačovaných anilitem/ digenitem (obr. 20). Dále vytváŕí i nepravidelná alotriomorfní zrna vystupující v asociaci s pyritem a kasiteritem nebo srůstající s aikinitem a emplektitem, které jsou obrůstány geeritem (obr. 16). Lokálně zatlačuje cuprobismutit (obr. 19). Jeho chemické složení (tab. 14) je v souladu $\mathrm{s}$ ideálním vzorcem $\mathrm{Cu}_{3} \mathrm{BiS}_{3}$, zjištěny byly jen minoritní obsahy $\mathrm{Ag}$ a Se nepřevyšující 0.01 apfu. Průměrný empirický vzorec (17 bodových analýz) na bázi 7 apfu je $\mathrm{Cu}_{3.01} \mathrm{Ag}_{0.01} \mathrm{Bi}_{0.98} \mathrm{~S}_{3.00}$.
Tabulka 16 Chemické složení monazitu-(Ce), xenotimu(Y) a zirkonu z Hřebečné (hm. \%)

\begin{tabular}{|c|c|c|c|c|c|c|}
\hline minerál & monazi & $-(\mathrm{Ce})$ & xenotin & T-(Y) & zirko & \\
\hline $\mathrm{P}_{2} \mathrm{O}_{5}$ & 30.29 & 30.13 & 37.10 & 36.55 & 2.42 & 0. \\
\hline $\mathrm{As}_{2} \mathrm{O}_{5}$ & 0.07 & 0.04 & bdl & 0.26 & 1.28 & 0. \\
\hline $\mathrm{SiO}_{2}{ }^{3}$ & 0.55 & 0.49 & bdl & bdl & 23.48 & 28.2 \\
\hline $\mathrm{ZrO}_{2}^{2}$ & bdl & bdl & 0.17 & 0.10 & 51.06 & 59. \\
\hline $\mathrm{HfO}_{2}^{2}$ & bdl & bdl & bdl & bdl & 2.49 & \\
\hline $\mathrm{ThO}_{2}$ & 11.58 & 12.61 & 0.70 & 0.19 & 0.21 & 0. \\
\hline $\mathrm{O}_{2}{ }^{2}$ & 1.20 & 1.94 & 0.25 & bdl & 0.56 & 0.0 \\
\hline $\mathrm{I}_{2} \mathrm{O}_{3}$ & bdl & bdl & bdl & bdl & 0.71 & 0.0 \\
\hline $\mathrm{Sc}_{2} \mathrm{O}_{3}$ & bdl & bdl & bdl & bdl & 0.70 & 0. \\
\hline $\mathrm{Y}_{2} \mathrm{O}_{3}$ & 2.75 & 3.07 & 44.30 & 43.56 & 3.79 & 0.2 \\
\hline $\mathrm{La}_{2} \mathrm{O}_{3}$ & 9.83 & 9.14 & bdl & bdl & bdl & \\
\hline $\mathrm{Ce}_{2} \mathrm{O}_{3}$ & 23.02 & 22.20 & bdl & bdl & bdl & \\
\hline $\mathrm{r}_{2} \mathrm{O}_{3}$ & 2.95 & 2.74 & bdl & bdl & bdl & \\
\hline $\mathrm{Nd}_{2} \mathrm{O}_{3}$ & 10.20 & 9.46 & bdl & bdl & bdl & \\
\hline $\mathrm{Sm}_{2} \mathrm{O}_{3}$ & 2.25 & 2.13 & 0.63 & 0.91 & bdl & \\
\hline $\mathrm{Eu}_{2} \mathrm{O}_{3}$ & 0.19 & 0.18 & 0.44 & 0.24 & bdl & \\
\hline $\mathrm{Gd}_{2} \mathrm{O}_{3}$ & 1.58 & 1.76 & 3.07 & 3.72 & 0.18 & \\
\hline $\mathrm{Tb}_{2} \mathrm{O}_{3}$ & bdl & bdl & 0.75 & 0.99 & bdl & \\
\hline $\mathrm{Dy}_{2}{ }_{2} \mathrm{O}_{3}$ & 0.76 & 1.10 & 6.57 & 7.09 & 0.79 & \\
\hline $\mathrm{Ho}_{2} \mathrm{O}_{3}$ & bdl & bdl & 1.00 & 1.01 & bdl & \\
\hline $\mathrm{Er}_{2} \mathrm{O}_{3}$ & 0.17 & 0.18 & 2.54 & 2.57 & 0.43 & \\
\hline $\mathrm{Tm}_{2} \mathrm{O}_{3}$ & bdl & bdl & 0.40 & 0.38 & bdl & \\
\hline $\mathrm{Yb}_{2} \mathrm{O}_{3}^{\circ}$ & bdl & bdl & 2.07 & 1.96 & 0.51 & \\
\hline $\mathrm{Lu}_{2}^{2} \mathrm{O}_{3}$ & bdl & bdl & 0.43 & 0.39 & bdl & \\
\hline $\mathrm{CaO}^{\circ}$ & 2.16 & 2.86 & 0.16 & 0.04 & 1.26 & 0. \\
\hline $\mathrm{SrO}$ & bdl & bdl & bdl & bdl & 0.36 & \\
\hline $\mathrm{BaO}$ & bdl & bdl & bdl & bdl & 0.08 & \\
\hline InO & bdl & bdl & bdl & bdl & 0.13 & \\
\hline $\mathrm{eO}$ & bdl & bdl & 0.78 & 0.24 & 1.11 & \\
\hline $\mathrm{PbO}$ & 0.17 & 0.29 & bdl & bdl & bdl & \\
\hline$F$ & bdl & bdl & bdl & bdl & 0.63 & \\
\hline total & 99.73 & 100.33 & 101.36 & 100.20 & 92.18 & 92. \\
\hline $\mathrm{P}$ & 0.993 & 0.986 & 1.014 & 1.014 & 0.072 & 0.00 \\
\hline$s$ & 0.001 & 0.001 & bdl & 0.004 & 0.023 & \\
\hline Si & 0.021 & 0.019 & bdl & bdl & 0.824 & 0.9 \\
\hline subtot. & 1.016 & 1.006 & 1.014 & 1.019 & 0.919 & 0.96 \\
\hline $\mathrm{Zr}$ & bdl & bdl & 0.003 & 0.002 & 0.873 & $0.9 \mathrm{~s}$ \\
\hline $\mathrm{Hf}$ & bdl & bdl & bdl & bdl & 0.025 & 0.03 \\
\hline Th & 0.102 & 0.111 & 0.005 & 0.001 & 0.002 & \\
\hline U & 0.010 & 0.017 & 0.002 & 0.000 & 0.004 & \\
\hline $\mathrm{Al}$ & bdl & bdl & bdl & bdl & 0.029 & \\
\hline Sc & bdl & bdl & bdl & bdl & 0.021 & 0.0 \\
\hline Y & 0.057 & 0.063 & 0.761 & 0.760 & 0.071 & 0.0 \\
\hline La & 0.140 & 0.130 & bdl & bdl & bdl & \\
\hline $\mathrm{Ce}$ & 0.326 & 0.314 & bdl & bdl & bdl & \\
\hline $\operatorname{Pr}$ & 0.042 & 0.039 & bdl & bdl & bdl & \\
\hline $\mathrm{Nd}$ & 1 & 31 & dl & bdl & bdl & \\
\hline $\mathrm{Sm}$ & 0.030 & 0.028 & 0.007 & 0.010 & bdl & \\
\hline Eu & 0.003 & 0.002 & 0.005 & 0.003 & bdl & \\
\hline $\mathrm{Gd}$ & 0.020 & 0.023 & 0.033 & 0.040 & 0.002 & \\
\hline $\mathrm{Tb}$ & bdl & bdl & 0.008 & 0.011 & bdl & \\
\hline Dy & 0.010 & 0.014 & 0.068 & 0.075 & 0.009 & \\
\hline $\mathrm{Ho}$ & bdl & bdl & & 11 & bdl & \\
\hline $\mathrm{Er}$ & 0.002 & 0.002 & 0.026 & 0.026 & 0.005 & \\
\hline $\mathrm{Tm}$ & bdl & bdl & 0.004 & 0.004 & bdl & \\
\hline $\mathrm{Yb}$ & bdl & bdl & 0.020 & 0.020 & 0.005 & \\
\hline Lu & bdl & bdl & 0.004 & 0.004 & bdl & \\
\hline $\mathrm{Ca}$ & 0.089 & 0.117 & 0.005 & 0.001 & 0.047 & 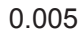 \\
\hline $\mathrm{Sr}$ & bdl & bdl & bdl & bdl & 0.007 & \\
\hline $\mathrm{Ba}$ & bdl & bdl & bdl & bdl & 0.001 & \\
\hline $\mathrm{Mn}$ & bdl & bdl & bdl & bdl & 0.004 & \\
\hline $\mathrm{Fe}$ & bdl & bdl & 0.021 & 0.007 & 0.033 & 0.0 \\
\hline $\mathrm{Pb}$ & 0.002 & 0.003 & bdl & bdl & bdl & \\
\hline subtot. & 0.973 & 0.994 & 0.982 & 0.974 & 1.139 & 1.05 \\
\hline $\mathrm{F}$ & bdl & bdl & bdl & bdl & 0.070 & \\
\hline $\mathrm{Ce} / \mathrm{Ce}^{*}$ & 1.03 & 1.06 & & & & \\
\hline $\mathrm{Eu} / \mathrm{Eu}^{*}$ & 0.31 & 0.29 & 0.96 & 0.40 & & \\
\hline $\mathrm{Yb} / \mathrm{Yb}^{*}$ & & & 0.74 & 0.75 & & \\
\hline
\end{tabular}

Koeficienty empirických vzorců počítány na bázi 40. 


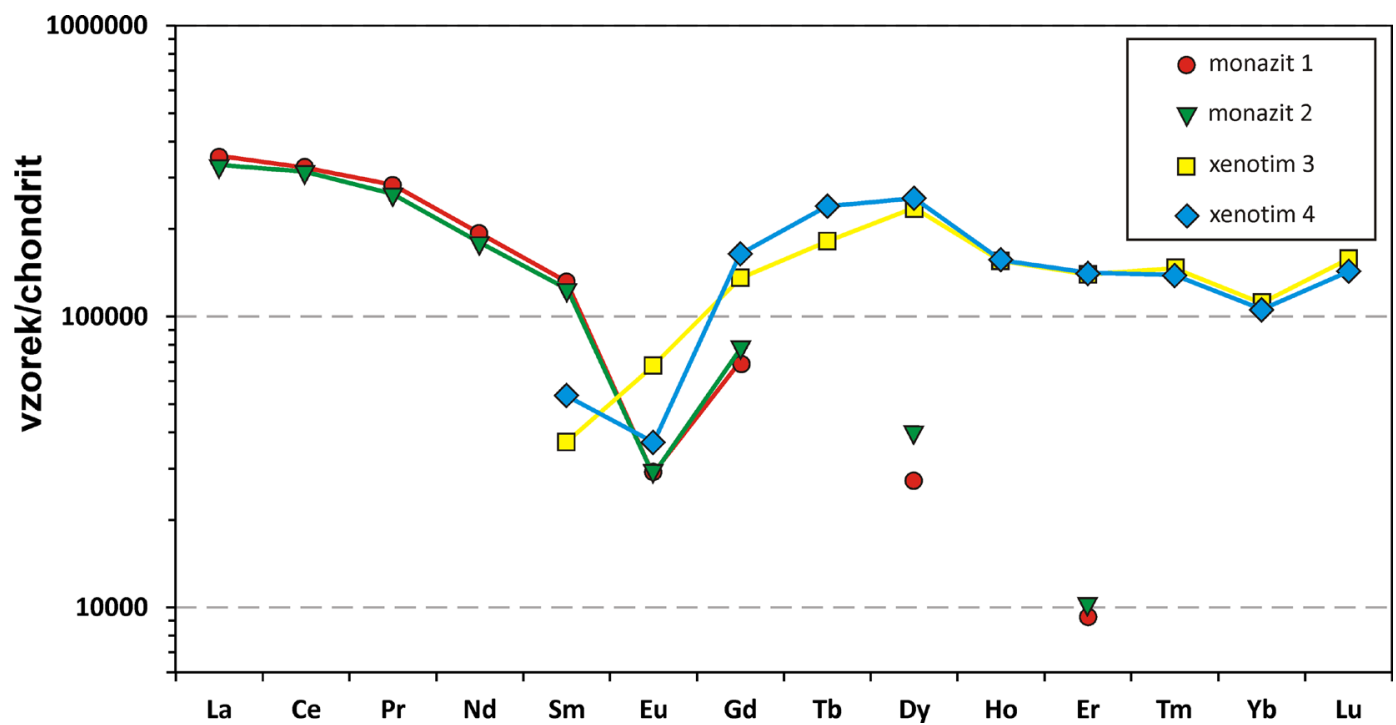

Obr. 21 Chondritem normalizované distribuce prvků vzácných zemin v monazitu-(Ce) a xenotimu-(Y) z Hřebečné.

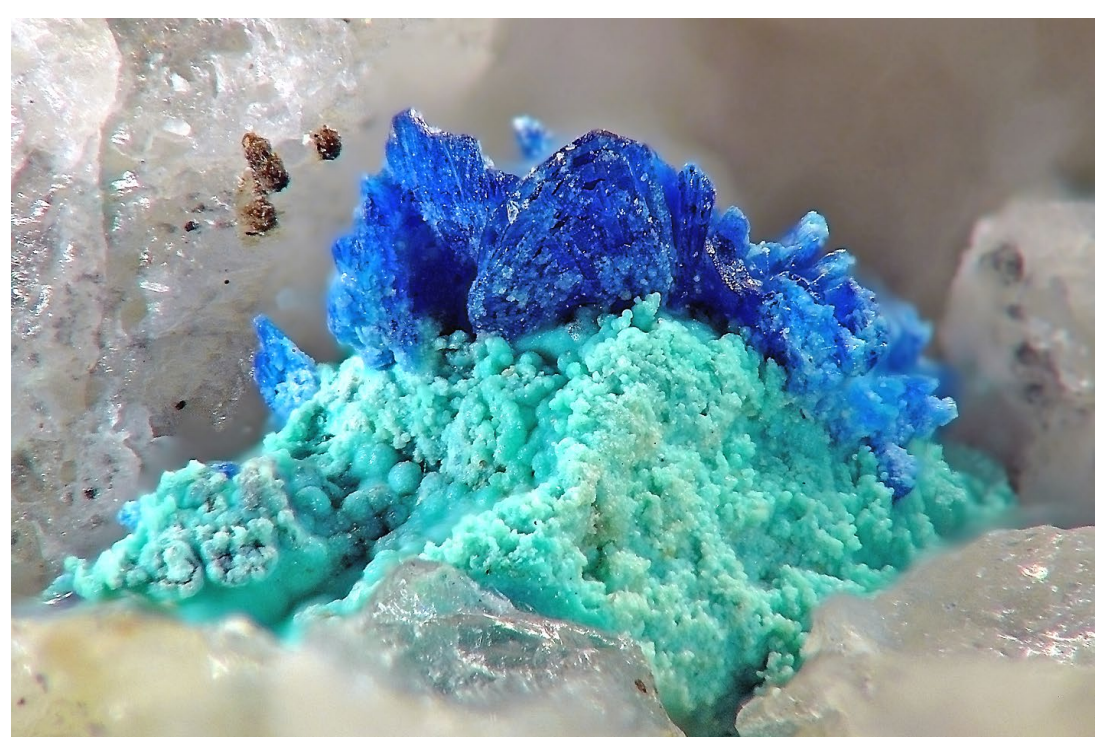

Obr. 22 Bohatá skupina nápadně modrých krystalů mrázekitu narůstající na světle modrozelené agregáty pseudomalachitu, Hřebečná; šírka záběru $3 \mathrm{~mm}$, foto P. Fuchs.

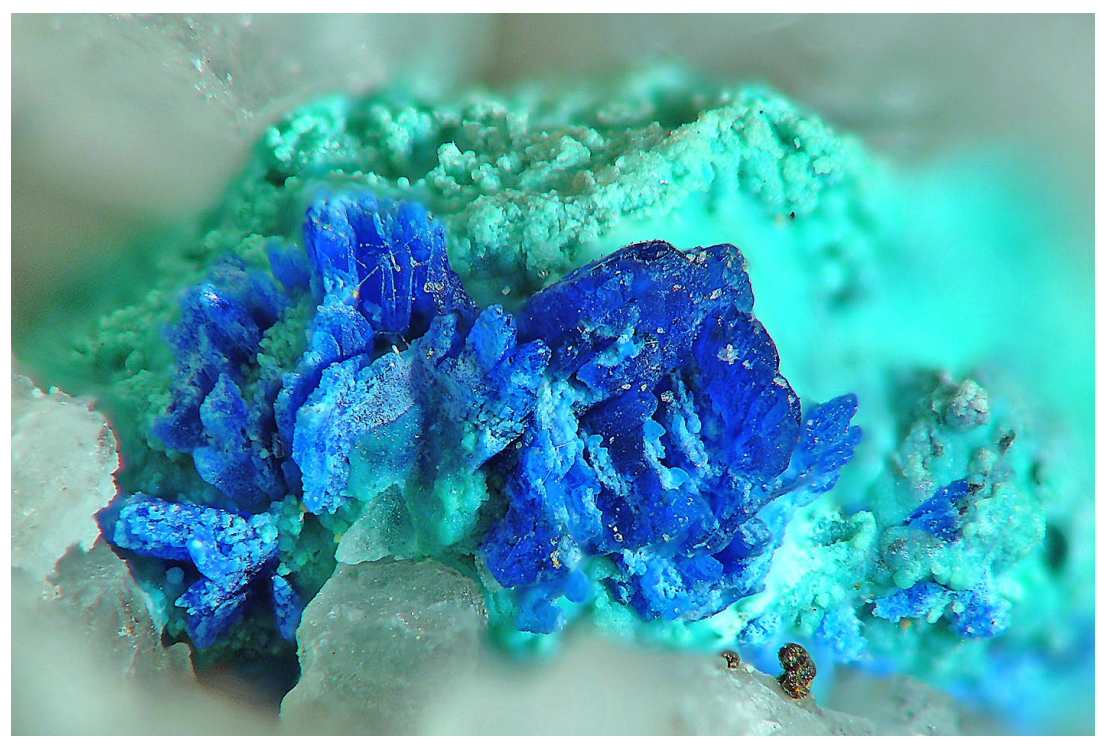

Obr. 23 Nedokonale vyvinuté protáhle tabulkovité modré krystaly mrázekitu narůstající na světle modrozelené agregáty pseudomalachitu, Hřebečná; šírka záběru $3 \mathrm{~mm}$, foto $P$. Fuchs.

\section{Další hypogenní minerály}

Křemen je hlavní složkou studované žiloviny. Většinou je středně až hrubě zrnitý, v drúzových dutinách o velikosti do $5 \mathrm{~cm}$ vytváří skupiny ojediněle až $4 \mathrm{~cm}$ velkých krystalů. Barva křemene je bílá, místy slabě našedlá či nahnědlá. Ojediněle se vyskytly nedokonale vyvinuté krystaly a zrnité agregáty světle fialového ametystu.

Fluorapatit je hojnou součástí žlloviny, kde se vyskytuje $v$ podobě více či méně navětralých zrn a nedokonale hexagonálně omezených až několik $\mathrm{cm}$ velkých krystalů šedobílé, světle zelené či nahnědlé barvy. $V$ některých vzorcích je fluorapatit $v$ křemenné žilovině korodován či zcela vyloužen, takže po něm zbyly jen více či méně hexagonálně omezené dutiny, na které je $v$ některých prípadech vázána supergenní Bi-Cu mineralizace. Chemické složení fluorapatitu odpovídá stechiometrii tohoto minerálního druhu; v kationtu byly zjištěné pravidelné minoritní obsahy Mn v rozmezí 0.02 - 0.13 apfu a lokálně i obsahy Al (do 0.07 apfu) a Fe, $\mathrm{Sr}, \mathrm{Mg}$ (do $0.05 \mathrm{apfu}$ ). $\mathrm{V}$ aniontu je pak $\mathrm{P}$ pouze ojediněle substituován As (do 0.09 apfu) a podle zjištěných obsahů $\mathrm{F}$ jde o krajní fluorapatitový člen bez $\mathrm{Cl}$ a $\mathrm{OH}$. Reprezentativní chemické analýzy a koeficienty empirických vzorců na bázi $3 \mathrm{P}+\mathrm{As}$ apfu jsou uvedeny $v$ tabulce 15.

Kasiterit je ve studovaném materiálu velmi vzácný. $\mathrm{V}$ křemenné žilovině ojediněle vytváří agregáty o velikosti do $100 \mu \mathrm{m}$; častěji jen idiomorfní až oválná zrna o velikosti do $30 \mu \mathrm{m}$ (obr. 9). Po chemické stránce je velmi čistý, jen v některých zrnech 
Tabulka 17 Rentgenová prášková data mrázekitu z Hřebečné

\begin{tabular}{|c|c|c|c|c|c|c|c|c|c|c|c|c|c|c|c|c|c|}
\hline$I_{o b s .}$ & $d_{o b s .}$ & $d_{\text {calc. }}$ & $h$ & $k$ & I & $I_{o b s .}$ & $d_{o b s .}$ & $d_{\text {calc. }}$ & $h$ & $k$ & 1 & $I_{\text {obs. }}$ & $d_{o b s .}$ & $d_{\text {calc. }}$ & $h$ & $k$ & - \\
\hline 78.3 & 7.631 & 7.635 & 1 & 0 & 1 & 25.2 & 2.6804 & 2.6804 & 3 & 0 & -5 & 2.4 & 1.9147 & 1.9146 & 3 & 0 & $\overline{7}$ \\
\hline 84.5 & 6.093 & 6.094 & 1 & 0 & -3 & 13.7 & 2.6012 & 2.6016 & 3 & 1 & 1 & 1.8 & 1.9090 & 1.9091 & 2 & 3 & \\
\hline 35.9 & 5.413 & 5.416 & 0 & 1 & 2 & 19.4 & 2.5761 & 2.5764 & 2 & 2 & -2 & 10.5 & 1.8865 & 1.8865 & 4 & 0 & -8 \\
\hline 61.8 & 5.202 & 5.204 & 0 & 0 & 4 & 2.4 & 2.5175 & 2.5181 & 1 & 2 & 4 & 5.3 & 1.8790 & 1.8791 & 1 & 3 & -5 \\
\hline 35.1 & 5.150 & 5.153 & 1 & 1 & -1 & 19.4 & 2.5010 & 2.5011 & 2 & 0 & 6 & 0.9 & 1.8387 & 1.8386 & 4 & 2 & -1 \\
\hline 2.1 & 4.852 & 4.856 & 1 & 1 & -2 & 19.2 & 2.4554 & 2.4557 & 1 & 1 & 7 & 10.3 & 1.8191 & 1.8191 & 4 & 2 & 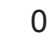 \\
\hline 1.2 & 4.679 & 4.682 & 0 & 1 & 3 & 22.2 & 2.3526 & 2.3528 & 1 & 2 & 5 & 8.6 & 1.8055 & 1.8055 & 0 & 3 & 6 \\
\hline 33.1 & 4.416 & 4.418 & 2 & 0 & -2 & 0.8 & 2.3198 & 2.3182 & 2 & 2 & -5 & 7.3 & 1.7546 & 1.7542 & 2 & 0 & 10 \\
\hline 0.9 & 3.898 & 3.899 & 1 & 1 & -4 & 20.6 & 2.3033 & 2.3032 & 2 & 1 & -8 & 8.4 & 1.7409 & 1.7407 & 5 & 0 & 1 \\
\hline 25.3 & 3.816 & 3.817 & 2 & 0 & 2 & 10.0 & 2.2207 & 2.2206 & 4 & 0 & 0 & 6.5 & 1.7348 & 1.7346 & 0 & 0 & 12 \\
\hline 24.9 & 3.637 & 3.638 & 2 & 1 & 0 & 12.8 & 2.2091 & 2.2090 & 1 & 1 & -9 & 3.9 & 1.7324 & 1.7325 & 5 & 1 & -1 \\
\hline 39.4 & 3.442 & 3.443 & 1 & 1 & -5 & 26.0 & 2.2010 & 2.2012 & 3 & 1 & -7 & 2.8 & 1.7134 & 1.7132 & 1 & 1 & 11 \\
\hline 2.1 & 3.241 & 3.243 & 2 & 1 & -4 & 29.4 & 2.1971 & 2.1972 & 2 & 2 & -6 & & & 1.6988 & 3 & 1 & -11 \\
\hline 34.1 & 3.171 & 3.172 & 0 & 2 & 0 & 39.1 & 2.1859 & 2.1860 & 3 & & -1 & & & 1.6986 & 3 & 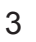 & 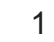 \\
\hline 3.6 & 3.135 & 3.135 & 0 & 2 & 1 & 8.7 & 2.1346 & 2.1360 & 1 & (6) & 9 & 6.2 & 1.6768 & 1.6766 & 2 & 1 & -12 \\
\hline 100.0 & 3.044 & 3.044 & 0 & 1 & 6 & 18.2 & 2.0888 & 2.0887 & 3 & & 5 & 5.1 & 1.6601 & 1.6600 & 4 & 1 & 6 \\
\hline 78.3 & 3.017 & 3.017 & 3 & 0 & -1 & 3.1 & 2.0563 & 2.0563 & 1 & 3 & -1 & 2.6 & 1.6559 & 1.6560 & 1 & 3 & r \\
\hline 65.2 & 3.007 & 3.007 & 1 & 0 & -7 & 26.5 & 2.0472 & 2.0472 & 3 & 2 & -5 & 4.4 & 1.6396 & 1.6391 & 3 & 2 & 7 \\
\hline 4.0 & 2.987 & 2.987 & 1 & 2 & 0 & 3.6 & 2.0311 & 2.0313 & 3 & 0 & -9 & 2.1 & 1.6352 & 1.6354 & 4 & 2 & 4 \\
\hline 71.3 & 2.928 & 2.929 & 1 & 2 & 1 & 7.3 & 2.0116 & 2.0116 & 0 & 2 & 8 & 1.9 & 1.6070 & 1.6068 & 2 & 3 & -8 \\
\hline 3.3 & 2.820 & 2.821 & 1 & 2 & 2 & 14.2 & 1.9667 & 1.9665 & 4 & 1 & -6 & 3.9 & 1.5858 & 1.5858 & 0 & 4 & 0 \\
\hline 3.9 & 2.812 & 2.813 & 1 & 2 & -3 & 1.5 & 1.9440 & 1.9441 & 1 & 3 & -4 & 3.9 & 1.5817 & 1.5812 & 0 & 4 & 1 \\
\hline 17.0 & 2.775 & 2.775 & 2 & 1 & 4 & 7.6 & 1.9316 & 1.9315 & 1 & 0 & -11 & 6.3 & 1.5714 & 1.5709 & 3 & 3 & -7 \\
\hline
\end{tabular}

Tabulka 18 Parametry základní cely mrázekitu (pro monoklickou prostorovou grupu $P 2, / n$ )

\begin{tabular}{lllllll}
\hline & & $a[\AA]$ & $b[\AA]$ & $c[\AA]$ & $\beta\left[{ }^{\circ}\right]$ & $V\left[\AA^{3}\right]$ \\
\hline Hřebečná & tato práce & $9.0672(6)$ & $6.3432(3)$ & $21.2481(13)$ & $101.587(5)$ & $1197.17(12)$ \\
L'ubietová & Števko et al. (2016) & $9.067(5)$ & $6.341(4)$ & $21.252(9)$ & $101.6(4)$ & $1197(1)$ \\
L'ubietová & Effenberger et al. (1994) & $9.065(1)$ & $6.341(1)$ & $21.238(2)$ & $101.61(1)$ & $1195.8(2)$ \\
Gadernheim & Effenberger et al. (1994) & $9.065(1)$ & $6.340(1)$ & $21.239(3)$ & $101.57(1)$ & $1195.5(2)$ \\
\hline
\end{tabular}

byly lokálně zjištěny minoritní obsahy $\mathrm{Ta}_{2} \mathrm{O}_{5}, \mathrm{Nb}_{2} \mathrm{O}_{5} \mathrm{a}$ FeO, které nepřevyšují $0.20-0.30$ hm. \%.

Zirkon vytváří ojedinělé protažené idiomorfní krystaly o délce do $40 \mu \mathrm{m}$ zarůstající do křemenné žiloviny. Dvě WDS analýzy ukázaly nízké analytické sumy kolem $92 \mathrm{hm}$. \% (tab. 16) a porušenou stechiometrii, pravděpodobně díky jeho metamiktizaci, způsobené zvýšeným obsahem U. Alterovaný charakter podtrhují i zvýšené obsahy $\mathrm{Al}, \mathrm{Ca}, \mathrm{Fe}, \mathrm{F}$ a As. Zvýšené obsahy Hf, Sc, U, Y a $\mathrm{P}$ naznačují, že by mohlo jít o magmatogenní zirkon pocházející z hostitelského granitu v okolí studovaných křemenných žil, které se vyznačuji obdobným složením (srov. Breiter et al. 2006).

Monazit-(Ce) byl pozorován jako ojedinělá nepravidelná zrna o velikosti do $30 \mu \mathrm{m} v$ křemenné žilovině. Chemické složení monazitu (tab. 16) se vyznačuje vysokým obsahem Th ( 12 hm. \% ThO $)_{2}$, který vylučuje jeho hydrotermální původ (srov. např. Zhu, O’Nions 1999; Schandl, Gorton 2004). Předpokládáme tedy, že jde, podobně jako v případě zirkonu, o „xenokryst“, pocházející z okolního granitu. S uvedenou interpretací je v souladu i absence $\mathrm{Ce}$ anomálie $\left(\mathrm{Ce} / \mathrm{Ce}^{*}=1.0\right)$ a výrazná negativní Eu anomálie $\left(E u / E u^{*}=0.3\right)$, které jsou rovněž charakteristické pro monazity z krušnohorských granitů (srov. Breiter, Förster 2021)

Xenotim-(Y) byl zjištěn jen velmi ojediněle jako protáhlé nepravidelné zrno o velikosti do $30 \mu \mathrm{m}$. Dvě orientační WDS analýzy ukázaly, že cca $20 \%$ strukturní pozice yttria je zastupováno středně těžkými a těžkými prvky vzácných zemin (tab. 16). Nízké obsahy U (do $0.25 \mathrm{hm}$. $\left.\% \cup_{2}\right)$, variabilní Eu anomálie $\left(E u / E^{*}=0.4\right.$ a 1.0) a
Tabulka 19 Chemické složení mrázekitu z Hřebečné (hm. \%)

\begin{tabular}{lrrrrrr}
\hline & mean & 1 & 2 & 3 & 4 & 5 \\
\hline $\mathrm{FeO}$ & 0.15 & 0.17 & 0.18 & 0.11 & 0.15 & 0.17 \\
$\mathrm{CuO}$ & 26.82 & 26.30 & 26.69 & 27.56 & 26.79 & 26.77 \\
$\mathrm{ZnO}$ & 0.05 & 0.07 & 0.00 & 0.00 & 0.11 & 0.05 \\
$\mathrm{Bi}_{2} \mathrm{O}_{3}$ & 50.64 & 51.07 & 50.56 & 50.60 & 50.62 & 50.34 \\
$\mathrm{As}_{2} \mathrm{O}_{5}$ & 0.51 & 0.17 & 0.83 & 0.74 & 0.42 & 0.39 \\
$\mathrm{P}_{2} \mathrm{O}_{5}$ & 15.49 & 15.91 & 15.25 & 15.27 & 15.61 & 15.39 \\
$\mathrm{~F}$ & 0.26 & 0.20 & 0.29 & 0.25 & 0.32 & 0.24 \\
$\mathrm{H}_{2} \mathrm{O}^{*}$ & 5.86 & 5.75 & 5.82 & 6.03 & 5.81 & 5.89 \\
$\mathrm{O}_{\mathrm{F}} \mathrm{F}_{2}$ & -0.11 & -0.08 & -0.12 & -0.10 & -0.13 & -0.10 \\
\hline total & 99.66 & 99.55 & 99.49 & 100.44 & 99.69 & 99.14 \\
\hline $\mathrm{Fe}$ & 0.019 & 0.020 & 0.023 & 0.013 & 0.018 & 0.021 \\
$\mathrm{Cu}$ & 3.029 & 2.932 & 3.022 & 3.127 & 3.012 & 3.056 \\
$\mathrm{Zn}$ & 0.005 & 0.007 & 0.000 & 0.000 & 0.012 & 0.006 \\
\hline$\Sigma$ & 3.054 & 2.960 & 3.045 & 3.141 & 3.042 & 3.083 \\
\hline $\mathrm{Bi}$ & 1.953 & 1.944 & 1.955 & 1.961 & 1.943 & 1.962 \\
\hline $\mathrm{As}$ & 0.040 & 0.013 & 0.065 & 0.058 & 0.033 & 0.031 \\
$\mathrm{P}$ & 1.960 & 1.987 & 1.935 & 1.942 & 1.967 & 1.969 \\
\hline$\Sigma$ & 2.000 & 2.000 & 2.000 & 2.000 & 2.000 & 2.000 \\
\hline $\mathrm{F}$ & 0.122 & 0.094 & 0.136 & 0.117 & 0.148 & 0.115 \\
$\mathrm{OH}$ & 1.843 & 1.657 & 1.817 & 2.046 & 1.764 & 1.937 \\
\hline$\Sigma$ & 1.965 & 1.750 & 1.953 & 2.163 & 1.912 & 2.052 \\
\hline $\mathrm{H} \mathrm{O}$ & 2.000 & 2.000 & 2.000 & 2.000 & 2.000 & 2.000 \\
\hline $\mathrm{mean}$ & $-\mathrm{pr} \mathrm{n} \mathrm{r}$ & & &
\end{tabular}

mean - průměr z pěti bodových analýz; koeficienty empirických vzorců počíány na bázi $\mathrm{P}+\mathrm{As}=2$ apfu; $\mathrm{H}_{2} \mathrm{O}^{*}$ - obsah dopočtený na základě vyrovnání nábojů a ideálního obsahu $2 \mathrm{H}_{2} \mathrm{O}$. 


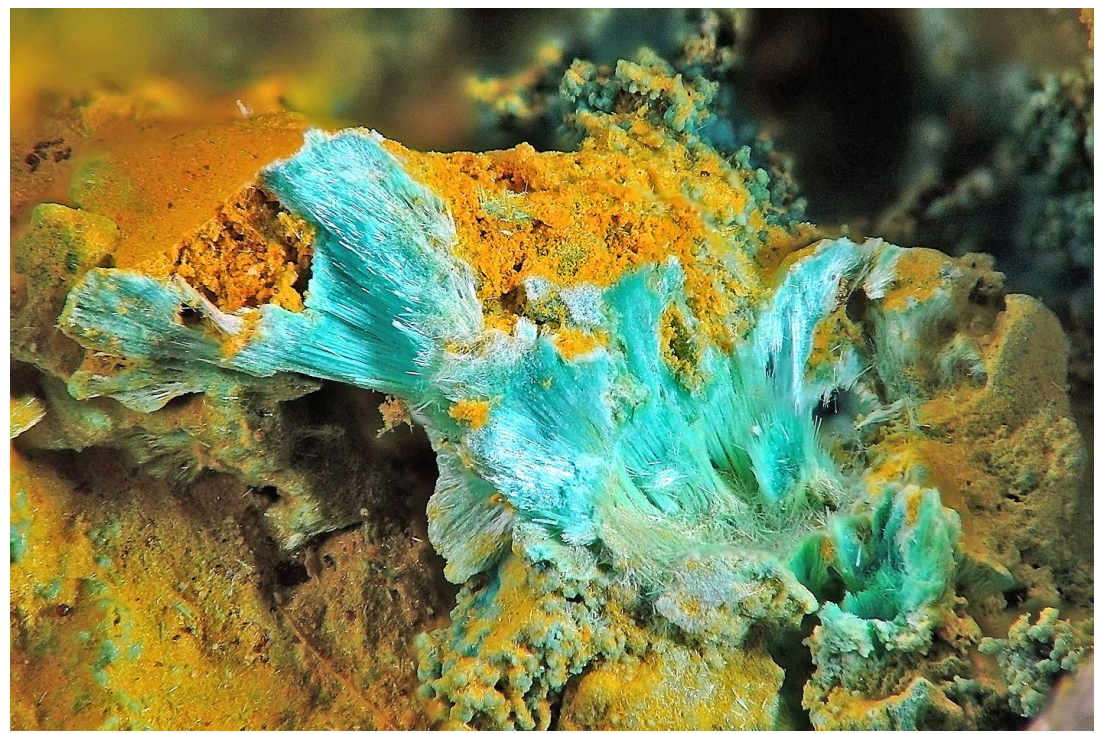

Obr. 24 Bohatá skupina modrozelených jehlicovitých krystalů mixitu $v$ dutině žiloviny, Hřebečná; šiřrka záběru $6 \mathrm{~mm}$, foto $P$. Fuchs.

Tabulka 20 Rentgenová prášková data mixitu z Hřebečné

\begin{tabular}{|c|c|c|c|c|c|c|c|c|c|c|c|c|c|c|c|c|c|}
\hline$I_{\text {obs. }}$ & $d_{o b s .}$ & $d_{\text {calc. }}$ & $h$ & $k$ & 1 & $I_{\text {obs. }}$ & $d_{o b s .}$ & $d_{\text {calc. }}$ & $h$ & $k$ & 1 & $I_{\text {obs. }}$ & $d_{o b s .}$ & $d_{\text {calc }}$ & $h$ & $k$ & 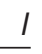 \\
\hline 100.0 & 11.816 & 11.796 & 1 & 0 & 0 & 17.7 & 2.5742 & 2.5741 & 4 & 1 & 0 & 1.6 & 1.7025 & 1.7026 & 4 & 4 & U \\
\hline 2.9 & 6.816 & 6.810 & 1 & 1 & 0 & 6.7 & 2.4654 & 2.4645 & 1 & 2 & 2 & 1.1 & 1.6852 & 1.6851 & 3 & 5 & 0 \\
\hline 1.0 & 5.902 & 5.898 & 2 & 0 & 0 & 1.2 & 2.2325 & 2.2328 & 2 & 2 & 2 & .8 & .6371 & 1.6372 & 6 & 0 & 2 \\
\hline 14.2 & 4.461 & 4.458 & 1 & 2 & 0 & 0.8 & 2.1943 & 2.1939 & 3 & 1 & 2 & \multirow{2}{*}{1.6} & \multirow{2}{*}{1.6208} & 1.6206 & 3 & 5 & 1 \\
\hline 4.1 & 4.178 & 4.176 & 2 & 0 & 1 & 3.6 & 2.1188 & 2.1186 & 5 & 1 & 0 & & & 1.6206 & 5 & 3 & 1 \\
\hline 8.5 & 3.933 & 3.932 & 3 & 0 & 0 & \multirow{2}{*}{1.5} & \multirow{2}{*}{2.0860} & 2.0860 & 4 & 2 & 1 & 0.9 & 1.5922 & 1.5919 & 5 & 2 & 2 \\
\hline 13.5 & 3.561 & 3.560 & 1 & 2 & 1 & & & 2.0860 & 2 & 4 & 1 & 1.1 & 1.5623 & 1.5624 & 7 & 1 & 0 \\
\hline 2.8 & 406 & 3.405 & 2 & 2 & 0 & 0.8 & 1.9966 & 1.9965 & 3 & 2 & 2 & 0.7 & 1.5369 & 1.5369 & 6 & 1 & 2 \\
\hline 14.1 & 3.272 & 3.272 & 3 & 1 & 0 & 1.8 & 1.9394 & 1.9392 & 4 & 3 & 0 & 0.4 & 1.4787 & 1.4787 & 0 & 0 & 4 \\
\hline 19.7 & 2.950 & 2.949 & 4 & 0 & 0 & 1.5 & 1.8426 & 1.8427 & 4 & 3 & 1 & 0.4 & 1.4637 & 1.4641 & 7 & 0 & 2 \\
\hline \multirow{2}{*}{4.9} & \multirow{2}{*}{2.863} & 2.863 & 1 & 3 & 1 & 1.9 & 1.8001 & 1.8008 & 3 & 3 & 2 & 1.1 & 1.4411 & 1.4411 & 2 & 7 & 0 \\
\hline & & 2.863 & 3 & 1 & 1 & 2.2 & 1.7802 & 1.7801 & 2 & 4 & 2 & 0.6 & 1.3999 & 1.4001 & 7 & 2 & 1 \\
\hline 10.8 & 2.707 & 2.706 & 2 & 3 & 0 & 1.4 & 1.7223 & 1.7223 & 1 & 5 & 2 & 0.6 & 1.3811 & 1.3815 & 1 & 7 & 5 \\
\hline
\end{tabular}

Tabulka 21 Parametry základní cely mixitu a zálesiitu (pro hexagonální prostorovou grupu P6_/m)

\begin{tabular}{lllll}
\hline mixit & & $a[\AA]$ & $c[\AA]$ & $V\left[\AA^{3}\right]$ \\
\hline Hřebečná & tato práce & $13.6207(5)$ & $5.9148(6)$ & $950.31(9)$ \\
Přísečnice & Sejkora et al. (2019) & $13.631(17)$ & $5.9336(5)$ & $955(1)$ \\
Krupka & Sejkora et al. (2013) & $13.631(1)$ & $5.912(1)$ & $951.3(1)$ \\
H. Slavkov & Sejkora et al. (2006) & $13.605(2)$ & $5.909(1)$ & 947.2 \\
Jáchymov & Frost et al. (2010) & $13.620(1)$ & $5.903(1)$ & $948.2(2)$ \\
Smrkovec & Sejkora et al. (1997) & $13.6482(9)$ & $5.9148(8)$ & $954.1(1)$ \\
Smrkovec & Frost et al. (2010) & $13.637(1)$ & $5.910(1)$ & $951.8(2)$ \\
Cínovec & Sejkora, Šrein (1996) & $13.598(6)$ & $5.916(6)$ & $947(1)$ \\
& Mereiter, Preisinger (1986) & $13.646(2)$ & $5.920(1)$ & 954.7 \\
\hline zálesíit & & & & $937.8(2)$ \\
\hline Zálesí & Sejkora et al. (1999) & $13.571(1)$ & $5.880(1)$ & $938.9(4)$ \\
Zálesí & Čejka et al. (2011) & $13.570(2)$ & $5.887(2)$ & $945(1)$ \\
Fuka mine & Tanaka et al. (2009) & $13.656(9)$ & $5.850(4)$ & 950.8 \\
S. Lucia & Olmi et al. (1991) & 13.631 & 5.906 & 946.4 \\
S. Lucia & Olmi et al. (1991) & 13.615 & 5.900 & 946.4 \\
S. Lucia & Olmi et al. (1991) & 13.641 & 5.898 & 949.2 \\
S. Lucia & Olmi et al. (1991) & 13.625 & 5.903 & 953.6 \\
M. Cidro & Olmi et al. (1991) & 13.650 & 5.915 & 946.4 \\
M. Cidro & Olmi et al. (1991) & 13.613 & 5.899 & 950.8 \\
S. Duchesa & Olmi et al. (1991) & 13.633 & 5.906 & \\
\hline & & & & \\
\hline
\end{tabular}


negativní $\mathrm{Yb}$ anomálie $\left(\mathrm{Yb} / \mathrm{Yb}^{*}=0.75\right)$ jsou odlišné od složení xenotimů z hostitelských granitů (René 2014; Breiter, Förster 2021) a nasvědčují tedy spíše hydrotermálnímu původu analyzovaného xenotimu (Bau, Möller 1992). S představou hydrotermální krystalizace xenotimu v otevřeném systému (Irber 1999) je v souladu i zřetelný tetrádový efekt typu $\mathrm{M}$, jasně patrný na chondritem normalizované křivce REE v oblasti třetí tetrády (obr. 21).

\section{Charakteristika supergenní mineralizace}

Nejzajímavějším supergenním minerálem bismutu je na lokalitě bezesporu vzácný mrázekit, jehož zdejší výskyt je po ojedinělých nálezech $v$ Jáchymově (Ondruš et al. 1997) druhým v České republice. Díky své barvě byl dřive patrně považován za azurit, a proto unikal větší pozornosti. Mrázekit vytvárí ve vyvětralých dutinách žiloviny ojedinělé temně nebesky modré agregáty o velikosti do 2 mm (obr. 22) složené z průsvitných, křehkých, nedokonale vyvinutých, protáhle tabulkovitých krystalů (obr. 23) o délce do $1 \mathrm{~mm}$. V asociaci byly zjištěny minerály alunitové superskupiny a pseudomalachit.

Rentgenová prášková data mrázekitu (tab. 17) odpovídají publikovaným údajům pro tuto minerální fázi i teoretickému záznamu vypočtenému z krystalové struktury (Effenberger et al. 1994). Zpřesněné parametry základní cely mrázekitu $z$ Hřebečné jsou v tabulce 18 porovnány $\mathrm{s}$ publikovanými hodnotami pro tuto minerální fázi.

Chemické složení mrázekitu z Hřebečné odpoví-
Tabulka 22 Chemické složení mixitu z Hřebečné (hm. \%)

\begin{tabular}{lrrrr}
\hline & mean & 1 & 2 & 3 \\
\hline $\mathrm{CaO}$ & 1.03 & 1.04 & 1.12 & 0.93 \\
$\mathrm{FeO}$ & 0.33 & 0.00 & 0.61 & 0.39 \\
$\mathrm{PbO}$ & 2.46 & 2.43 & 2.45 & 2.50 \\
$\mathrm{CuO}$ & 43.53 & 42.60 & 43.77 & 44.24 \\
$\mathrm{Al}_{2} \mathrm{O}_{3}$ & 0.20 & 0.20 & 0.17 & 0.24 \\
$\mathrm{Bi}_{2} \mathrm{O}_{3}$ & 15.16 & 14.51 & 15.49 & 15.47 \\
$\mathrm{As}_{2} \mathrm{O}_{5}$ & 29.13 & 28.67 & 28.54 & 30.20 \\
$\mathrm{P}_{2} \mathrm{O}_{5}$ & 2.13 & 2.06 & 2.18 & 2.15 \\
$\mathrm{H}_{2} \mathrm{O}^{*}$ & 9.58 & 9.26 & 9.80 & 9.70 \\
\hline total & 103.56 & 100.76 & 104.11 & 105.83 \\
\hline $\mathrm{Ca}$ & 0.194 & 0.199 & 0.214 & 0.170 \\
$\mathrm{Fe}$ & 0.049 & 0.000 & 0.092 & 0.055 \\
$\mathrm{~Pb}$ & 0.117 & 0.117 & 0.118 & 0.115 \\
$\mathrm{Cu}$ & 5.791 & 5.767 & 5.917 & 5.694 \\
$\mathrm{Al}$ & 0.042 & 0.041 & 0.036 & 0.048 \\
$\mathrm{Bi}$ & 0.688 & 0.671 & 0.715 & 0.680 \\
$\mathrm{As}$ & 2.682 & 2.687 & 2.670 & 2.690 \\
$\mathrm{P}$ & 0.318 & 0.313 & 0.330 & 0.310 \\
$\mathrm{OH}$ & 5.259 & 5.068 & 5.698 & 5.023 \\
$\mathrm{H} \mathrm{H}_{2} \mathrm{O}$ & 3.000 & 3.000 & 3.000 & 3.000 \\
\hline
\end{tabular}

mean - průměr ze tři bodových analýz; koeficienty empirických vzorců počitány na bázi $\mathrm{As}+\mathrm{P}=3$ apfu; $\mathrm{H}_{2} \mathrm{O}^{*}$ - obsah dopočtený na základě vyrovnání nábojů a ideálního obsahu $3 \mathrm{H}_{2} \mathrm{O}$.

dá ideálnímu vzorci $\mathrm{Bi}_{2} \mathrm{Cu}_{3}\left(\mathrm{PO}_{4}\right)_{2}$ $\mathrm{O}_{2}(\mathrm{OH})_{2} \cdot 2 \mathrm{H}_{2} \mathrm{O}$ (tab. 19); v kationtu byly zjištěny i minoritní obsahy $\mathrm{Fe}$ a Zn nepřevyšující 0.02 a 0.01 apfu. $\mathrm{V}$ aniontové části vzorce je dominantní $\mathrm{P}$ minoritně substituován As (do 0.06 apfu); $(\mathrm{OH})$ skupiny jsou v nevelkém rozsahu (do $0.15 \mathrm{apfu}$ ) zastupovány F. Empirický vzorec (průměr pěti bodových analýz) je možno na bázi $\mathrm{P}+\mathrm{As}=2$ apfu vyjádřit jako $\mathrm{Bi}_{1.95}\left(\mathrm{Cu}_{3.03} \mathrm{Fe}_{0.02} \mathrm{Zn}_{0.01}\right)_{\Sigma 3.06}\left(\mathrm{PO}_{4}\right)_{1.96}$ $\left(\mathrm{AsO}_{4}\right)_{0.04} \mathrm{O}_{2}(\mathrm{OH})_{1.84} \mathrm{~F}_{0.12} \cdot 2 \mathrm{H}_{2} \mathrm{O}$.

Mixit byl vzácně zjištěn $v$ dutinách křemenné žiloviny $\mathrm{v}$ podobě bohatých zelenomodrých agregátů $\mathrm{s}$ hedvábným leskem o velikosti do $5 \mathrm{~mm}$, které jsou složené $\mathrm{z}$ jehlicovitých krystalů (obr. 24). Jednotlivé krystaly mixitu jsou průsvitné až průhledné, se skelným leskem a jejich délka nepřevyšuje $3 \mathrm{~mm}$. $V$ asociaci s ním se vyskytují pseudomalachit a libethenit.

Obr. 25 Žluté až žlutozelené drobně krystalické agregáty minerálů superskupiny alunitu $v$ dutině křemenné žiloviny; Hřebečná; šířka záběru $5 \mathrm{~mm}$, foto P. Fuchs.

Obr. 26 Graf Ca vs. Sr (apfu) pro minerály superskupiny alunitu z Hřebečné.
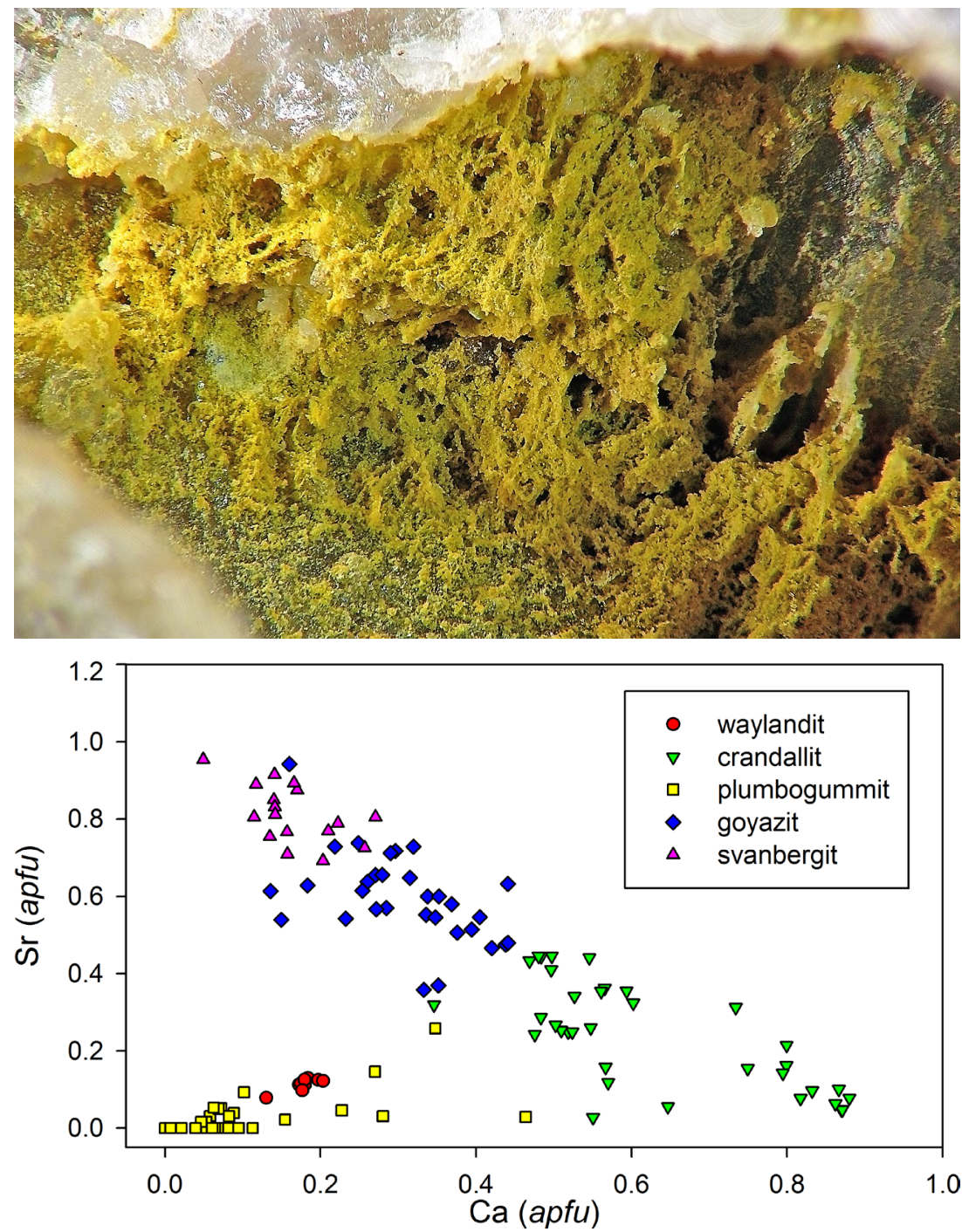


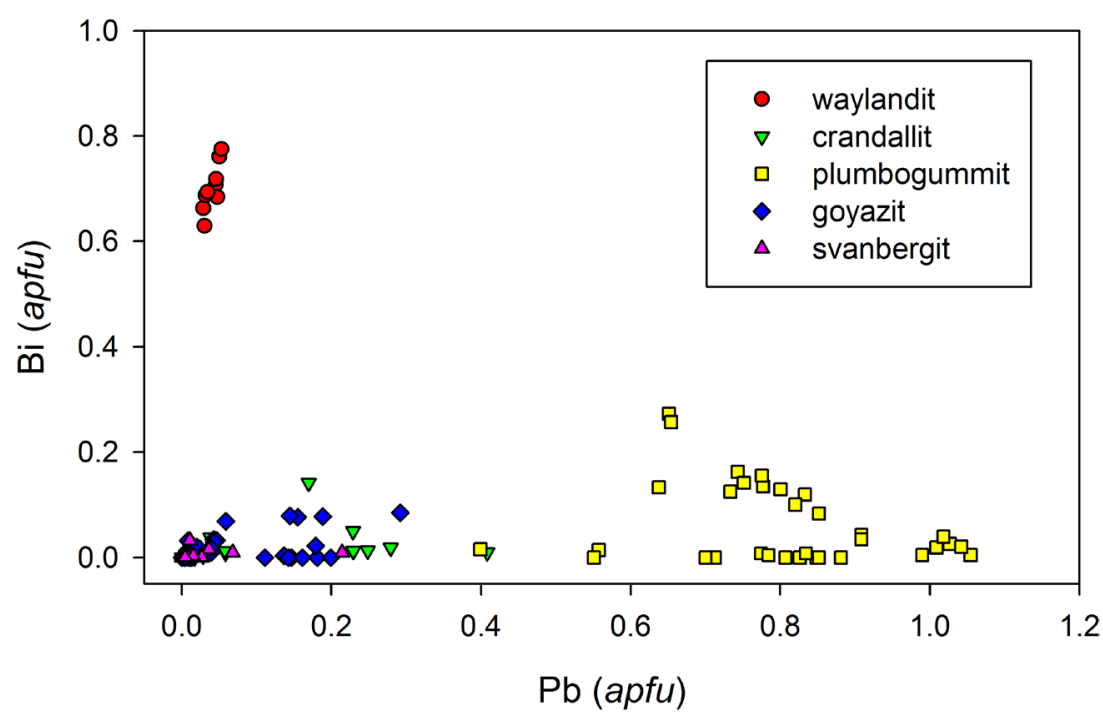

Obr. 27 Graf Pb vs. Bi (apfu) pro minerály superskupiny alunitu z Hřebečné.
Rentgenová prášková data mixitu (tab. 20) odpovídají teoretickým hodnotám vypočteným z krystalové struktury, publikovaným $v$ práci Mereiter, Preisinger (1986). Zpřesněné parametry jeho základní cely (tab. 21) jsou v souladu s publikovanými daty pro mixit. Rentgenová prášková data ani zpřesněné mřižkové parametry však nepostačují ke zcela jednoznačnému rozlišení jednotlivých Bi-Ca-REE As-dominantních členů mixitové skupiny (viz též Olmi et al. 1991; Sejkora, Šrein 1996; Plášil et al. 2009).

Chemické složení minerálů skupiny mixitu Ize vyjádřit obecným vzorcem $A \mathrm{Au}_{6}\left(\mathrm{TO}_{4}\right)_{3}(\mathrm{OH})_{6} \cdot 3 \mathrm{H}_{2} \mathrm{O}$. $\mathrm{Na}$ základě obsazení $A$ - a $T$ - pozic obecného vzorce jsou pak definovány jednotlivé minerální druhy této sku-

Tabulka 23 Chemické složení plumbogummitu z Hřebečné (hm. \%)

\begin{tabular}{|c|c|c|c|c|c|c|c|c|c|c|c|c|c|c|}
\hline & 1 & 2 & 3 & 4 & 5 & 6 & 7 & 8 & 9 & 10 & 11 & 12 & 13 & 14 \\
\hline $\mathrm{CaO}$ & 3.59 & 4.61 & 0.65 & 0.72 & 2.31 & 0.54 & 0.54 & 0.60 & 0.49 & 0.48 & 0.06 & 0.41 & 0.00 & 0.36 \\
\hline $\mathrm{BaO}$ & 0.00 & 0.00 & 0.00 & 0.00 & 0.46 & 0.00 & 0.00 & 0.00 & 0.00 & 0.00 & 0.00 & 0.42 & 0.00 & 0.00 \\
\hline $\mathrm{SrO}$ & 4.92 & 0.53 & 0.00 & 0.00 & 0.86 & 0.00 & 0.00 & 0.00 & 0.00 & 0.00 & 0.00 & 0.26 & 0.00 & 0.00 \\
\hline $\mathrm{PbO}$ & 16.40 & 22.04 & 23.61 & 23.05 & 28.30 & 27.25 & 28.44 & 30.57 & 30.19 & 33.60 & 34.74 & 35.63 & 34.44 & 37.96 \\
\hline $\mathrm{CuO}$ & 0.08 & 0.50 & 1.20 & 1.67 & 0.89 & 0.85 & 0.67 & 0.74 & 0.68 & 0.39 & 0.63 & 1.69 & 0.13 & 0.85 \\
\hline $\mathrm{ZnO}$ & 0.00 & 0.00 & 0.12 & 0.16 & 0.00 & 0.17 & 0.22 & 0.14 & 0.19 & 0.12 & 0.46 & 0.00 & 0.11 & 0.00 \\
\hline $\mathrm{Fe}_{2} \mathrm{O}_{3}$ & 0.82 & 0.38 & 8.43 & 10.56 & 1.09 & 8.44 & 11.54 & 5.41 & 6.75 & 1.68 & 15.14 & 1.42 & 9.22 & 1.77 \\
\hline $\mathrm{Al}_{2} \mathrm{O}_{3}$ & 28.71 & 27.89 & 19.05 & 17.99 & 28.99 & 19.03 & 17.15 & 22.32 & 21.32 & 24.15 & 12.68 & 23.19 & 17.79 & 23.58 \\
\hline $\mathrm{Bi}_{2}{ }_{2} \mathrm{O}_{3}$ & 0.66 & 0.59 & 10.32 & 9.45 & 0.00 & 5.69 & 4.80 & 3.91 & 4.53 & 1.33 & 0.69 & 1.45 & 0.90 & 0.78 \\
\hline $\mathrm{iO}_{2}$ & 0.00 & 0.00 & 0.00 & 0.00 & 0.00 & 0.00 & 0.06 & 0.00 & 0.00 & 0.07 & 0.22 & 0.00 & 0.06 & 0.00 \\
\hline $\mathrm{As}_{2} \mathrm{O}_{5}$ & 0.00 & 0.00 & 1.10 & 1.16 & 0.00 & 1.02 & 1.21 & 0.55 & 0.81 & 0.00 & 0.00 & 0.93 & 0.00 & 0.23 \\
\hline $\mathrm{P}_{2} \mathrm{O}_{5}$ & 24.22 & 24.45 & 22.37 & 21.50 & 25.65 & 21.57 & 21.53 & 23.31 & 22.55 & 23.44 & 19.87 & 21.52 & 21.26 & 22.71 \\
\hline $\mathrm{SO}_{3}{ }^{5}$ & 2.15 & 0.79 & 0.00 & 0.22 & 0.06 & 0.16 & 0.27 & 0.07 & 0.00 & 0.00 & 2.00 & 0.18 & 0.00 & 0.35 \\
\hline $\mathrm{F}$ & 2.51 & 2.79 & 1.32 & 1.29 & 3.23 & 1.70 & 1.64 & 2.27 & 2.38 & 3.27 & 0.81 & 0.68 & 0.56 & 0.40 \\
\hline $\mathrm{H}_{2} \mathrm{O}^{*}$ & 10.88 & 10.81 & 9.28 & 9.64 & 11.07 & 9.24 & 9.28 & 9.52 & 9.59 & 8.85 & 8.84 & 10.71 & 9.87 & 10.69 \\
\hline$=F$ & 1.06 & -1.17 & -0.55 & -0.54 & -1.36 & -0.72 & -0.69 & -0.96 & -1.00 & -1.38 & -0.34 & -0.29 & -0.24 & -0.17 \\
\hline total & 3.89 & 94.20 & 96.90 & 96.87 & 01.55 & 94.94 & 96.67 & 98.44 & 98.49 & 95.99 & 95.79 & 98.21 & 94.11 & 99.51 \\
\hline$\overline{\mathrm{Ca}}$ & 348 & 0.464 & 0.072 & .082 & 227 & 0.061 & 0.061 & 0.064 & 0.054 & 0.051 & 0.007 & 0.047 & 0.000 & 0.039 \\
\hline $\mathrm{Ba}$ & 000 & 0.000 & 0.000 & 0.000 & 017 & 0.000 & 0.000 & 0.000 & 0.000 & 0.000 & 0.000 & 0.017 & 0.000 & 0.000 \\
\hline $\mathrm{Sr}$ & 258 & 0.029 & 0.000 & 0.000 & 046 & .000 & 0.000 & 0.000 & 0.000 & 0.000 & .000 & 0.016 & 0.000 & 0.000 \\
\hline $\mathrm{Pb}$ & 399 & 0.557 & 0.652 & 0.654 & 700 & 0.776 & 0.801 & 0.820 & 0.833 & 0.909 & 1.009 & 1.018 & 1.027 & 1.042 \\
\hline$\underline{\mathrm{Bi}}$ & 015 & 0.014 & 0.273 & 0.257 & 0.000 & 0.155 & 0.129 & 0.100 & 0.120 & 0.034 & 0.019 & 0.040 & 0.026 & 0.021 \\
\hline$\overline{\Sigma A}$ & 020 & 1.064 & 0.996 & 0.993 & 0.990 & 0.992 & 0.991 & 0.985 & 1.006 & 0.994 & 1.035 & 1.138 & 1.052 & 1.102 \\
\hline$\overline{\mathrm{Fe}}$ & 056 & 0.027 & 0.650 & 0.838 & 075 & 0.672 & 0.909 & 0.406 & 0.521 & 0.127 & 1.229 & 0.114 & 0.768 & 0.136 \\
\hline $\mathrm{Cu}$ & 005 & 0.035 & 0.093 & 0.133 & 0.062 & 0.068 & 0.053 & 0.056 & 0.053 & 0.030 & 0.051 & 0.136 & 0.011 & 0.065 \\
\hline$n$ & 000 & 0.000 & 0.009 & 0.013 & .000 & 0.013 & 0.017 & 0.010 & 0.015 & 0.009 & 0.036 & 0.000 & 0.009 & 0.000 \\
\hline$\underline{\mathrm{Al}}$ & 3.060 & 3.088 & 2.302 & 2.236 & 3.140 & 2.372 & 2.114 & 2.621 & 2.575 & 2.859 & 1.613 & 2.901 & 2.322 & 2.834 \\
\hline$\overline{\Sigma B}$ & 3.121 & 3.150 & 3.054 & 3.220 & 3.277 & 3.124 & 3.092 & 3.093 & 3.164 & 3.025 & 2.929 & 3.151 & 3.110 & 3.036 \\
\hline$\overline{\mathrm{SiO}_{4}}$ & 0.000 & 0.000 & 0.000 & 0.000 & 0.000 & 0.000 & 0.006 & 0.000 & 0.000 & 0.007 & 0.024 & 0.000 & 0.007 & 0.000 \\
\hline $\mathrm{AsO}_{4}$ & 0.000 & 0.000 & 0.059 & 0.064 & 0.000 & 0.056 & 0.066 & 0.028 & 0.043 & 0.000 & 0.000 & 0.052 & 0.000 & 0.012 \\
\hline$\Omega^{4}$ & 0.995 & 0.950 & 1.218 & 1.200 & 1.010 & 1.107 & 1.066 & 1.087 & 1.070 & 1.033 & 0.960 & 0.850 & 0.966 & 0.906 \\
\hline $\mathrm{PO}_{3} \mathrm{OH}$ & 0.859 & 0.994 & 0.723 & 0.719 & 0.986 & 0.824 & 0.840 & 0.879 & 0.887 & 0.960 & 0.854 & 1.084 & 1.027 & 1.055 \\
\hline $\mathrm{SO}_{4}$ & 0.146 & 0.056 & 0.000 & 0.017 & 0.004 & 0.013 & 0.021 & 0.005 & 0.000 & 0.000 & 0.162 & 0.014 & 0.000 & 0.027 \\
\hline$\sum X$ & 2.000 & 2.000 & 2.000 & 2.000 & 2.000 & 2.000 & 2.000 & 2.000 & 2.000 & 2.000 & 2.000 & 2.000 & 2.000 & 2.000 \\
\hline $\bar{F}$ & .718 & 0.829 & 0.427 & 0.431 & 0.939 & 0.570 & 0.543 & 0.715 & 0.770 & 1.039 & 0.278 & 0.228 & 0.198 & 0.129 \\
\hline $\mathrm{OH}$ & 5.701 & 5.778 & 5.624 & 6.062 & 5.802 & 5.697 & 5.632 & 5.452 & 5.672 & 4.973 & 5.504 & 6.502 & 6.264 & 6.219 \\
\hline
\end{tabular}


piny. V A-pozici strukturního vzorce je možná široká izomorfie - zjištěny zde byly obsahy $\mathrm{Bi}, \mathrm{Al}, \mathrm{Y}$ a REE, Ca, $\mathrm{Pb}$ a v menší míře i dalších prvků; v aniontové $T$-pozici se izomorfně zastupují především As a $\mathrm{P}$ a $v$ menší míre i Si a další prvky (Olmi et al. 1991). Ve strukturní pozici $A$ studovaného mixitu z Hřebečné (tab. 22) převládá složka mixitová (0.67 0.71 apfu $\mathrm{Bi}$ ) nad zálesíitovou (0.17 - 0.21 apfu Ca), plumboagarditovou (0.11-0.12 apfu $\mathrm{Pb})$ a goudeyitovou (0.04 - 0.05 apfu Al); obsahy agarditové (Y,REE) komponenty ve studovaných vzorcích zjištěny nebyly. $\checkmark$ aniontové $T$ pozici vzorce As prévládá nad $\mathrm{P}$ s obsahy 0.31 až 0.33 apfu. Empirický vzorec studovaného mixitu (průměr tř́ bodových analýz) Ize na bázi $A s+P=3$ apfu vyjádřit jako $\left(\mathrm{Bi}_{0.69} \mathrm{Ca}_{0.19} \mathrm{~Pb}_{0.12} \mathrm{Al}_{0.04}\right)_{\Sigma 1.04}\left(\mathrm{Cu}_{5.79}\right.$ $\left.\mathrm{Fe}_{0.05}\right)_{\Sigma 5.84}\left[\left(\mathrm{AsO}_{4}\right)_{2.68}\left(\mathrm{PO}_{4}\right)_{0.32}\right]_{\Sigma 3.00}$ $(\mathrm{OH})_{526} \cdot 3 \mathrm{H}_{2} \mathrm{O}$.

Minerály alunitové superskupiny představují nejhojnější supergenní fáze zjištěné ve studovaném materiálu. Obvykle vytvářejí žluté, žlutozelené až hnědavě žluté práškovité až jemně krystalické povlaky a kůry o velikosti do několika $\mathrm{cm} v$ dutinách žiloviny (obr. 25). Rentgenová prášková data těchto minerálů dobře odpovídají záznamům uváděným pro ( $\mathrm{Pb}, \mathrm{Ca}, \mathrm{Sr}, \mathrm{Bi})-\mathrm{Al}-\mathrm{P}$ dominantní členy alunitové superskupiny (plumbogummit, crandallit, goyazit, waylandit). Vzhledem $\mathrm{k}$ jejich velmi výrazné chemické nehomogenitě (viz dále) nebyly pro tyto fáze zpřesňovány parametry základní cely.

Idealizovaný vzorec minerálů superskupiny alunitu je možno vyjádřit jako $A B_{3}\left(X_{4}\right)_{2}\left(\mathrm{OH}, \mathrm{H}_{2} \mathrm{O}\right)_{6}$. Pozice $A$ je obsazovaná velkými monovalentními $\left(\mathrm{Na}^{+}, \mathrm{K}^{+}, \mathrm{Rb}^{+}, \mathrm{Ag}^{+}\right.$, $\left.\mathrm{NH}_{4}^{+}, \mathrm{H}_{3} \mathrm{O}^{+}, \mathrm{Tl}^{+}\right)$, divalentními $\left(\mathrm{Ca}^{2+}\right.$, $\mathrm{Sr}^{2+}, \mathrm{Ba}^{2+}, \mathrm{Pb}^{2+}$ ) nebo trivalentními $\left(\mathrm{Bi}^{3+}, \mathrm{REE}^{3+} ; \mathrm{REE}=\right.$ prvky vzácných zemin, nejčastěji $\mathrm{Ce}^{3+}, \mathrm{La}^{3+}, \mathrm{Nd}^{3+}$, $\mathrm{Sm}^{3+}$ ) kationty. Pozice $B$ je obvykle obsazovaná trivalentními kationty jako $\mathrm{Fe}^{3+}, \mathrm{Al}^{3+}, \mathrm{Cr}^{3+}, \mathrm{V}^{3+}$ a $\mathrm{Ga}^{3+}$, v některých prípadech může obsahovat i divalentní (např. $\mathrm{Cu}^{2+}$ a $\mathrm{Zn}^{2+}$ ) nebo pentavalentní $\left(\mathrm{Sb}^{5+}\right)$ kationty. Pozice $X$ je tetraedricky koordinovaná, obvykle zde vystupuje $\mathrm{S}^{6+}, \mathrm{P}^{5+}$ a $\mathrm{As}^{5+}$, ale vzácněji může být obsazovaná i $\mathrm{C}^{4+}, \mathrm{Cr}^{6+}$ a Sij ${ }^{4+}$. V prípadě významného zastoupení divalentních kationtů $\mathrm{V}$ pozici $A$ a převahy $\mathrm{P}$ nebo As $\vee$ tetraedrické pozici $X$ je část aniontových skupin protonována za vzniku skupin $\left(\mathrm{PO}_{3} \mathrm{OH}\right)^{2-}$ nebo $\left(\mathrm{AsO}_{3} \mathrm{OH}\right)^{2-}$. Část $\mathrm{OH}$ skupin může být zastupova-

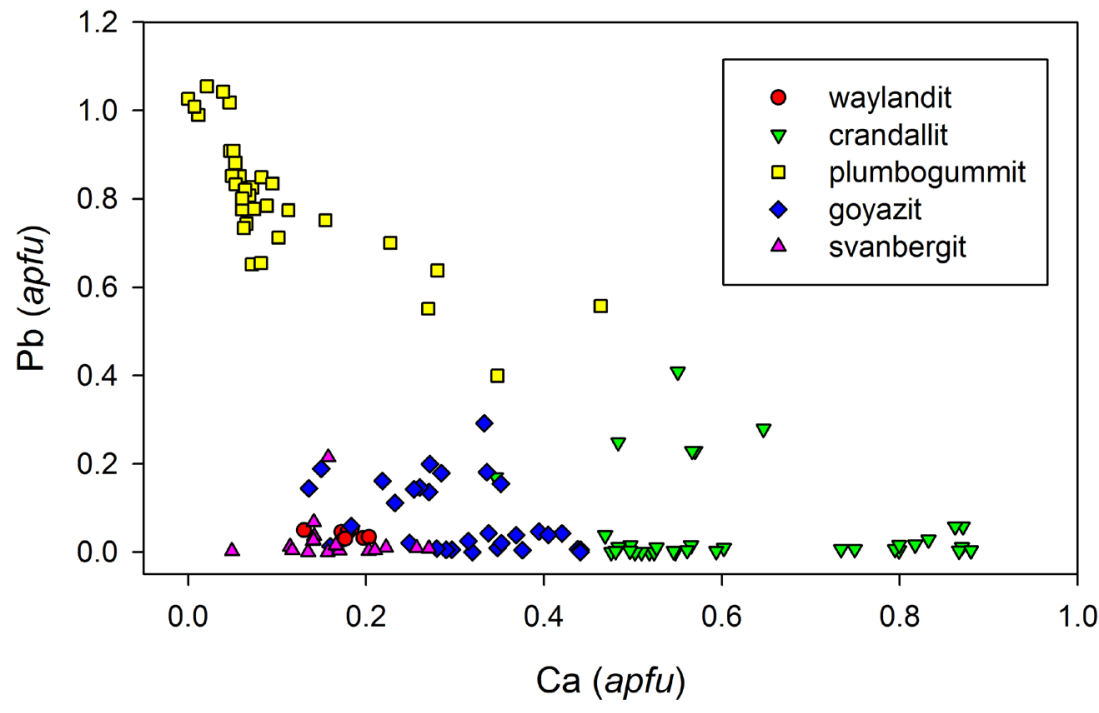

Obr. 28 Graf Ca vs. Pb (apfu) pro minerály superskupiny alunitu z Hřebečné.

Tabulka 24 Chemické složení waylanditu z Hřebečné (hm. \%)

\begin{tabular}{lrrrrrrrrr}
\hline & 1 & 2 & 3 & 4 & 5 & 6 & 7 & 8 & 9 \\
\hline $\mathrm{CaO}$ & 1.81 & 1.74 & 1.71 & 1.83 & 1.93 & 1.56 & 1.70 & 1.21 & 1.59 \\
$\mathrm{BaO}$ & 1.45 & 0.91 & 0.44 & 1.19 & 0.64 & 0.43 & 0.61 & 0.42 & 0.39 \\
$\mathrm{SrO}$ & 1.85 & 2.12 & 2.21 & 2.14 & 2.14 & 1.88 & 1.96 & 1.34 & 2.07 \\
$\mathrm{PbO}$ & 1.24 & 1.13 & 1.80 & 1.18 & 1.30 & 1.64 & 1.72 & 1.85 & 1.82 \\
$\mathrm{CuO}$ & 3.31 & 3.99 & 3.48 & 4.38 & 4.20 & 3.35 & 3.81 & 2.97 & 4.41 \\
$\mathrm{Fe}_{2} \mathrm{O}_{3}$ & 2.43 & 2.75 & 3.38 & 3.27 & 2.95 & 2.98 & 3.52 & 4.81 & 3.43 \\
$\mathrm{Al}_{2} \mathrm{O}_{3}$ & 22.51 & 22.58 & 22.13 & 21.48 & 22.45 & 22.42 & 22.93 & 22.04 & 21.80 \\
$\mathrm{Bi}_{2} \mathrm{O}_{3}$ & 26.79 & 27.43 & 27.09 & 26.50 & 27.36 & 26.63 & 28.20 & 29.39 & 27.86 \\
$\mathrm{As}_{2} \mathrm{O}_{5}$ & 2.68 & 1.46 & 0.17 & 0.00 & 0.18 & 0.56 & 0.14 & 0.88 & 0.00 \\
$\mathrm{P}_{2} \mathrm{O}_{5}$ & 24.29 & 24.30 & 24.01 & 23.48 & 23.92 & 22.58 & 23.82 & 22.99 & 21.89 \\
$\mathrm{H}_{2} \mathrm{O}^{*}$ & 9.08 & 9.64 & 9.88 & 10.01 & 10.22 & 10.03 & 10.57 & 10.07 & 10.74 \\
\hline $\mathrm{total}$ & 97.44 & 98.05 & 96.30 & 95.46 & 97.29 & 94.06 & 98.98 & 97.97 & 96.00 \\
\hline $\mathrm{Ca}$ & 0.177 & 0.175 & 0.179 & 0.197 & 0.203 & 0.172 & 0.180 & 0.130 & 0.184 \\
$\mathrm{Ba}$ & 0.052 & 0.033 & 0.017 & 0.047 & 0.025 & 0.017 & 0.024 & 0.017 & 0.016 \\
$\mathrm{Sr}$ & 0.098 & 0.115 & 0.126 & 0.125 & 0.122 & 0.112 & 0.112 & 0.078 & 0.130 \\
$\mathrm{~Pb}_{\mathrm{Bi}}$ & 0.030 & 0.029 & 0.047 & 0.032 & 0.034 & 0.045 & 0.046 & 0.050 & 0.053 \\
\hline$\Sigma \mathrm{A}$ & 0.629 & 0.663 & 0.684 & 0.688 & 0.694 & 0.708 & 0.719 & 0.761 & 0.775 \\
\hline $\mathrm{Cu}$ & 0.985 & 1.015 & 1.054 & 1.089 & 1.078 & 1.055 & 1.080 & 1.036 & 1.158 \\
\hline $\mathrm{Fe}$ & 0.228 & 0.283 & 0.258 & 0.333 & 0.312 & 0.261 & 0.284 & 0.225 & 0.359 \\
$\mathrm{Al}_{\Sigma \mathrm{B}}$ & 2.416 & 0.194 & 0.249 & 0.247 & 0.218 & 0.231 & 0.262 & 0.364 & 0.279 \\
\hline $\mathrm{AsO}$ & 2.810 & 2.971 & 3.062 & 3.127 & 3.131 & 3.215 & 3.217 & 3.196 & 3.411 \\
$\mathrm{PO}_{4}$ & 0.128 & 0.072 & 0.009 & 0.000 & 0.009 & 0.030 & 0.007 & 0.046 & 0.000 \\
$\mathrm{PO}_{3} \mathrm{OH}$ & 0.356 & 0.352 & 0.369 & 0.401 & 0.384 & 0.347 & 0.362 & 0.275 & 0.383 \\
\hline$\Sigma \mathrm{X}$ & 2.000 & 2.000 & 2.000 & 2.000 & 2.000 & 2.000 & 2.000 & 2.000 & 2.000 \\
\hline $\mathrm{OH}$ & 5.159 & 5.675 & 6.089 & 6.315 & 6.315 & 6.548 & 6.607 & 6.470 & 7.349 \\
\hline & 1.577 & 1.622 & 1.599 & 1.606 & 1.622 & 1.631 & 1.679 & 1.617 \\
\hline
\end{tabular}

1-9 reprezentativní bodové analýzy, koeficienty empirických vzorců počítány na bázi $\mathrm{P}+\mathrm{As}=2$ apfu; $\mathrm{H}_{2} \mathrm{O}^{*}$ - obsah dopočtený na základě vyrovnání nábojů. 


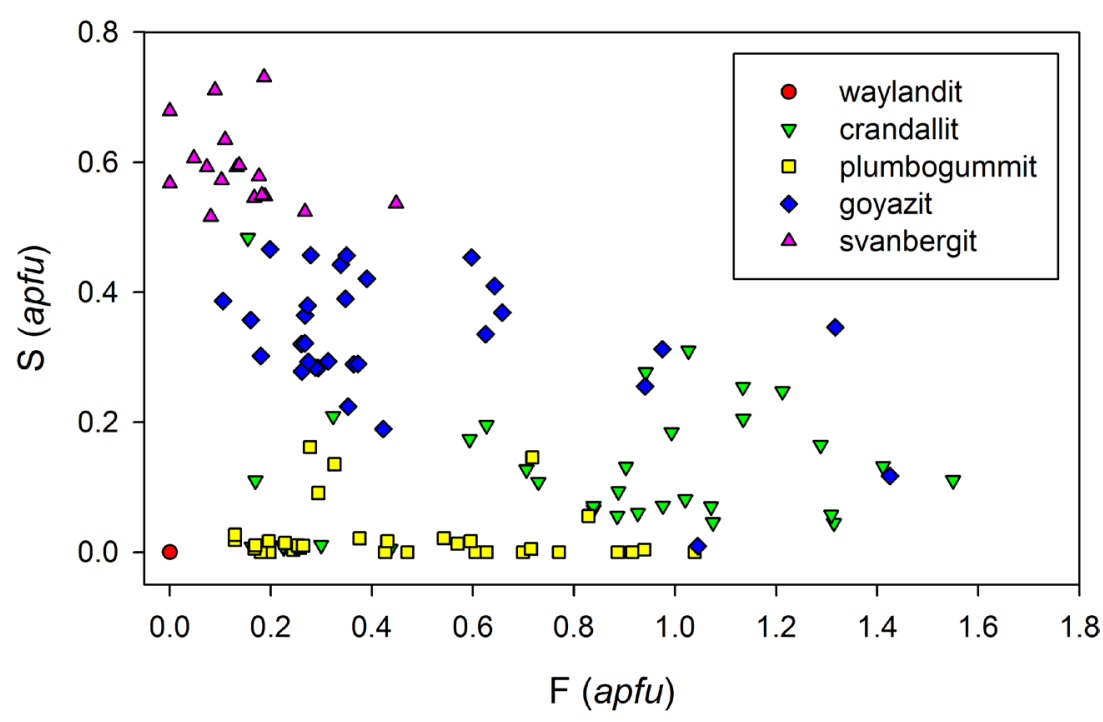

Obr. 29 Graf F vs. S (apfu) pro minerály superskupiny alunitu z Hřebečné. ná $\mathrm{O}, \mathrm{F}$ nebo $\mathrm{H}_{2} \mathrm{O}$ (Jambor, Dutrizac 1983; Scott 1987; Rattray et al. 1996; Jambor 1999; Kolitsch, Pring 2001; Sejkora et al. 2001; Grey et al. 2008; Mills et al. 2008; Sato et al. 2008; Grey et al. 2009; Mills et al. 2009; Sejkora et al. 2009; Bayliss et al. 2010, Vrtiška et al. 2019). Při studiu minerálů superskupiny alunitu z Hřebečné byla zjištěna v BSE obrazech jejich výrazná chemická nehomogenita vyvolaná zejména rozsáhlou izomorfií v A-pozici ideálního vzorce (obr. 26-29); zjištěny zde byly členy s dominantním zastoupením $\mathrm{Bi}, \mathrm{Ca}, \mathrm{Pb}$ a Sr; v menší míře pak i Al-Fe v B-pozici (obr. 30). V aniontu je převládající $P \vee$ některých vzorcích částečně substituován S (až do př́tomnosti svanbergitu - obr. 29), OH skupina je $v$

Tabulka 25 Chemické složení crandallitu z Hřebečné (hm. \%)

\begin{tabular}{|c|c|c|c|c|c|c|c|c|c|c|c|c|c|c|}
\hline & 1 & 2 & 3 & 4 & 5 & 6 & 7 & 8 & 9 & 10 & 11 & 12 & 13 & 14 \\
\hline$?$ & 56 & 5.11 & 5.79 & 33 & 43 & 74 & 5.58 & 5.86 & 7 & 1 & 835 & 86 & 0.50 & 1.07 \\
\hline & & Q & & 00 & & & & & & & & & & .00 \\
\hline & 07 & & & 83 & - & & & & & & & & & .11 \\
\hline & 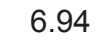 & 0 & 0 & 01 & 3 & 2 & 0 & 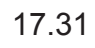 & & 73 & & 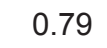 & 281 & 2.95 \\
\hline & 20 & 0.00 & 0 & مח0 & b & 9 & 20 & 71 & & 30 & & 3 & 0.70 & 0.74 \\
\hline${ }_{2} \mathrm{O}_{3}$ & 00 & 1.46 & 0.82 & 50 & 76 & 26 & 31 & 27 & 0.2 & 19 & 9 & .81 & .36 & 0.41 \\
\hline${ }_{2} \mathrm{O}_{3}$ & 3.15 & 8.62 & 1.87 & 0.77 & .00 & 2.19 & 29.45 & 29.94 & 32.95 & 3.21 & 0.80 & .01 & 33.37 & 34.31 \\
\hline${ }_{2} \mathrm{O}_{3}$ & .07 & 0.00 & 0.00 & 0.62 & 1.02 & 0.17 & 0.00 & 0.43 & 0.00 & 0.89 & .15 & 0.40 & 0.61 & 0.48 \\
\hline $\mathrm{S}_{2} \mathrm{O}_{5}$ & 0.00 & 0.00 & 0.00 & 0.00 & 0.00 & 0.00 & 0.00 & 00 & 0.00 & 0.38 & .00 & 0.00 & 0.00 & 0.00 \\
\hline${ }_{2} \mathrm{O}_{5}$ & .61 & 27.08 & 3.12 & 5.17 & 24.47 & 27.59 & 26.86 & 26.13 & 27.54 & 28.09 & .91 & 28.51 & 29.16 & 30.76 \\
\hline $\mathrm{O}_{2}$ & 62 & 0 & 8.32 & 3.08 & 4 & 1.83 & 11 & 92 & 4.39 & 75 & & .06 & 88 & 1.29 \\
\hline & 59 & 0.59 & 0.63 & 2.34 & 3.58 & 6.06 & 71 & 34 & & 17 & 48 & .48 & 1 & 3.61 \\
\hline${ }_{2} \mathrm{O}$ & .22 & 12.34 & 11.55 & 1.69 & 0.62 & 10.41 & 12.77 & 10.98 & 10.2 & 2.08 & 85 & .27 & 36 & 12.52 \\
\hline$F$ & .25 & -0.25 & -0.27 & -0.99 & .51 & -2.55 & -0.30 & -1.41 & -2 & .76 & & & 27 & -1.52 \\
\hline tal & .07 & 9.98 & 2.03 & .25 & 9.76 & 93.36 & 07 & 03 & 94. & & & 97.77 & 92 & 97.73 \\
\hline & 46 & 476 & 481 & 484 & 484 & 0.497 & 24 & 50 & & & & & & 0.878 \\
\hline & 10 & 0.343 & 000 & 00 & 07 & 0.008 & & & & & & & & 0.000 \\
\hline & 319 & 0.242 & 445 & 86 & 45 & 0.445 & 0.249 & 0.028 & & & & & 64 & 0.048 \\
\hline & & & & & & & & & & & & & & 059 \\
\hline & & & & & & & & & & & & & & 09 \\
\hline & & & & & & & & & & & & & & 94 \\
\hline & & & & & & & & & & & & & & 41 \\
\hline & & & & & & & & & & & & & & 23 \\
\hline & & & & & & & & & & & & & & 94 \\
\hline & & & & & & & & & & & & & & 59 \\
\hline & & . & 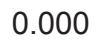 & 0.000 & 0 & 0. & & & & & & & & 0.000 \\
\hline & & 0.93 & 1.072 & 0.982 & 1.053 & 1.033 & 0.936 & 1. & 1. & 2 & & & & 1.015 \\
\hline $\mathrm{O}_{3} \mathrm{O}$ & 0.735 & 1.053 & 0.445 & 0.823 & 0.670 & 0.856 & 1.057 & 0.926 & 0.704 & 36 & 0.942 & 0.856 & 0.876 & 0.913 \\
\hline & 0.110 & 0.008 & 0.484 & 0.196 & 0.277 & 0.111 & 0.007 & 0.061 & 0.2 & 0.046 & 0.1 & 0.174 & 08 & 0.072 \\
\hline & .000 & 2.000 & .000 & 0 & & & & & & & & & & .000 \\
\hline $\bar{\Gamma}$ & & & & & & & & & & & & & & 0.845 \\
\hline $\mathrm{OH}$ & 6.051 & 6.098 & 5.522 & 5.777 & 5.222 & 4.757 & 6.407 & 5.492 & 4.447 & 5.630 & 5.544 & 5.840 & 5.442 & 5.271 \\
\hline
\end{tabular}

1-14 reprezentativní bodové analýzy, koeficienty empirických vzorců počítány na bázi $\mathrm{P}+\mathrm{As}+\mathrm{S}=2$ apfu; $\mathrm{H}_{2} \mathrm{O}^{*}-\mathrm{obsah}$ dopočtený na základě vyrovnání nábojů. 
omezené míře substituována fluorem (obr. 29). Reprezentativní chemické analýzy jednotlivých členů a jejich empirické vzorce na bázi $\mathrm{P}+\mathrm{S}+\mathrm{As}+$ $\mathrm{Si}=2$ apfu jsou uvedeny $\mathrm{v}$ tabulkách $23-26$.

Relativně hojný plumbogummit vytváří zrna až nepravidelné agregáty o velikosti do $50 \mu \mathrm{m}$ obrůstající a zatlačující agregáty mrázekitu (obr. 31) v asociaci s pseudomalachitem nebo vystupuje jako součást nehomogenních agregátů minerálů alunitové superskupiny $v$ asociaci $s$ crandallitem, goyazitem až svanbergitem (obr. 32). V A-pozici plumbogummitu je dominantní $\mathrm{Pb}(0.40$ - 1.05 apfu) doprovázeno obsahy $\mathrm{Ca}$ (do 0.46 apfu, obr. 28) a Bi (do 0.27 apfu, obr. 27), naproti tomu obsahy Sr (obr. 26)

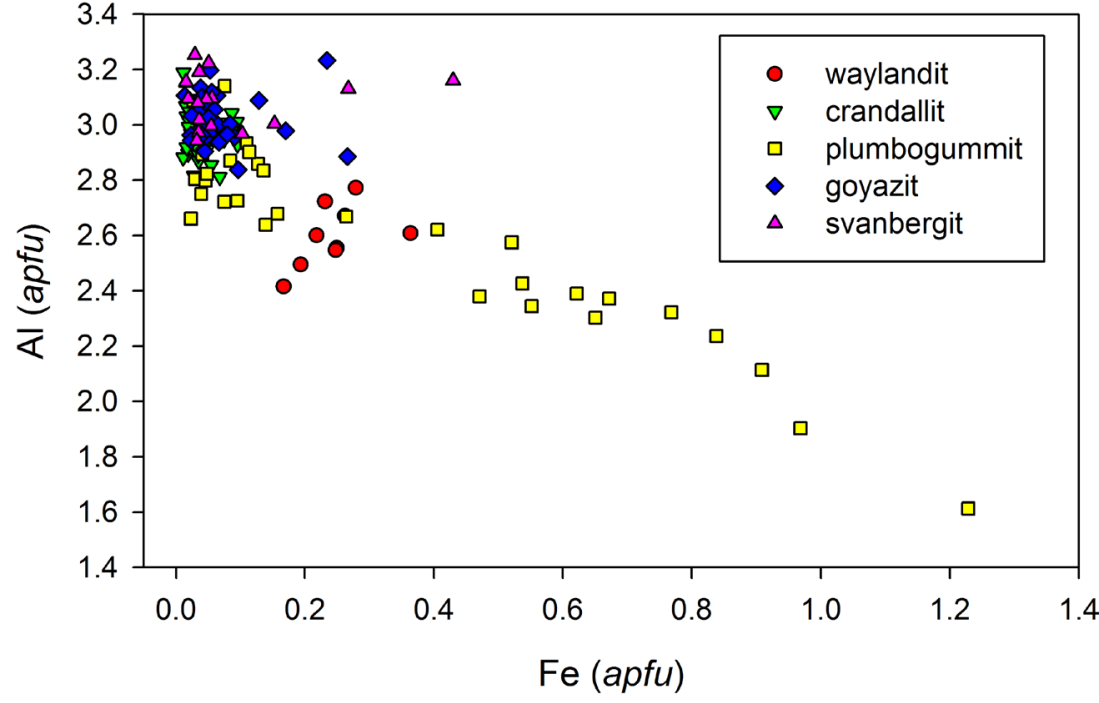

Obr. 30 Graf Fe vs. Al (apfu) pro minerály superskupiny alunitu z Hřebečné.

Tabulka 26 Chemické složení goyazitu a svanbergitu z Hřebečné (hm. \%)

\begin{tabular}{|c|c|c|c|c|c|c|c|c|c|c|c|c|c|c|}
\hline & \multicolumn{7}{|c|}{ goyazit } & \multicolumn{7}{|c|}{ svanbergit } \\
\hline & 1 & 2 & 3 & 4 & 5 & 6 & 7 & 8 & 9 & 10 & 11 & 12 & 13 & 14 \\
\hline $\mathrm{aO}$ & 3.40 & 3.94 & 3.98 & 1.95 & 5.14 & 2.91 & 3.72 & 1.73 & 1.56 & 1.36 & 2.34 & 1.49 & 3.00 & 1.31 \\
\hline $\mathrm{aO}$ & 47 & 0.00 & 0.37 & 0.25 & 0.00 & 0.37 & 0.57 & 1. & 0.00 & 0.58 & .24 & 0.00 & .20 & 0.35 \\
\hline $\mathrm{rO}$ & 6.76 & 11.42 & 12.52 & 12.34 & 13.61 & 13.16 & 15.67 & 18.84 & 16.52 & 17.66 & .83 & 15.40 & 5.66 & 18.44 \\
\hline bO & 11.88 & 0.42 & 0.92 & 2.50 & 0.00 & 6.52 & 0.00 & 0.58 & 1.58 & 0.57 & 0.20 & 0.00 & 0.43 & 0.20 \\
\hline $\mathrm{uO}$ & 0.71 & 0.07 & 0.00 & 0.12 & 0.08 & 0.26 & 0.00 & 0.00 & 0.00 & 1.71 & 0.00 & 0.00 & .13 & 0.07 \\
\hline $\mathrm{e}_{2} \mathrm{O}_{3}$ & 0.56 & 4.29 & 0.64 & 1.27 & 0.67 & 0.81 & 1.09 & 0.78 & 0.57 & 0.54 & 2.42 & 1.61 & .58 & 0.87 \\
\hline $\mathrm{I}_{2} \mathrm{O}_{3}$ & 29.11 & 29.73 & 30.45 & 29.04 & 32.85 & 31.18 & 31.58 & 30.34 & 30.23 & 31.76 & 30.42 & 29.81 & 31.58 & 30.54 \\
\hline $\mathrm{Bi}_{2} \mathrm{O}_{3}$ & 3.61 & 0.00 & 0.94 & 3.03 & 0.00 & 0.00 & 0.00 & 0.00 & 0.71 & 0.21 & 0.00 & 0.00 & 0.16 & 0.00 \\
\hline $\mathrm{As}_{2} \mathrm{O}_{5}$ & 0.00 & 0.70 & 0.00 & 0.00 & 0.00 & 2.37 & 0.00 & 2.19 & 0.00 & 0.73 & 0.50 & 0.68 & 0.36 & 0.19 \\
\hline $\mathrm{P}_{2} \mathrm{O}_{5}$ & 22.07 & 21.91 & 21.93 & 21.71 & 24.39 & 22.72 & 29.32 & 24.41 & 19.97 & 20.91 & 19.49 & 19.07 & 21.61 & 17.89 \\
\hline $\mathrm{SO}_{3}$ & 4.27 & 7.16 & 7.52 & 5.87 & 5.76 & 4.62 & 0.16 & 1.81 & 8.93 & .80 & .47 & .56 & .74 & 11.70 \\
\hline 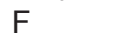 & 95 & 1.30 & 0.76 & 0.38 & 5.20 & 1.41 & 12 & 2 & 0.00 & .71 & .52 & 18 & .06 & 0.71 \\
\hline $\mathrm{H}_{2} \mathrm{O}^{*}$ & 99 & 11.45 & 11.52 & 11.12 & 11.35 & 12.49 & 11.89 & 28 & 68 & .79 & .99 & 10.85 & .73 & 11.41 \\
\hline$=F$ & -0.40 & -0.55 & -0.32 & -0.16 & -2.19 & -0.59 & -1.73 & -2.20 & 0.00 & -0.30 & -0.22 & -0.08 & -0.45 & -0.30 \\
\hline total & 95.38 & 91.84 & 91.23 & 89.42 & 96.86 & 98.23 & 96.38 & 96.15 & 91.75 & 98.04 & 93.20 & 88.58 & 94.79 & 93.38 \\
\hline $\mathrm{Sa}$ & 333 & 0.348 & 0.352 & 0.183 & 0.441 & 0.260 & 0.320 & 0.160 & 0.142 & 0.115 & 0.210 & 0.135 & 0.257 & 0.117 \\
\hline$a$ & 17 & 0.000 & 0.012 & 0.009 & 0.000 & 0.012 & 0 & 0 & 0 & 18 & 8 & 00 & 06 & 0.011 \\
\hline $6 r$ & & 0.545 & 0.600 & 0.628 & 0.632 & 0.6 & 0 & & & & & & & 0.890 \\
\hline b & 292 & 0.009 & 0.020 & 0.059 & 0.000 & 0.147 & 0.000 & 0.0 & 0. & 0.012 & 0. & 0.000 & 0.009 & 0.004 \\
\hline $\mathrm{Bi}$ & 0.085 & 0.000 & 0.020 & 0.069 & 0.000 & 0.000 & 0.000 & 0.000 & 0.016 & 0.004 & 0.000 & 0.000 & 0.003 & 0.000 \\
\hline$\Sigma A$ & 1.085 & 0.902 & 1.005 & 0.948 & 1.073 & 1.057 & 1.066 & 1.156 & 1.005 & 0.954 & 0.992 & 0.889 & 1.001 & 1.023 \\
\hline $\mathrm{Cu}$ & 49 & 0.004 & 0.000 & 0.008 & 0.005 & 0.0 & 00 & 0 & 0 & 02 & 00 & 00 & 08 & 0.004 \\
\hline e & & 0.266 & 0.040 & 0.084 & 0.040 & & & & & & & & & 0.054 \\
\hline $\mathrm{Al}$ & & 2.885 & 2.965 & 3.004 & 3.101 & 3.070 & & & & & & & 2.973 & 2.996 \\
\hline$B$ & 3.222 & 3.155 & 3.005 & 3.096 & 3.146 & 3.137 & 3.050 & 3.137 & 3.054 & 3.077 & 3.157 & 3.070 & & 3.055 \\
\hline $\mathrm{sO}_{4}$ & 0.000 & 0.030 & 0.000 & 0.000 & 0.000 & 0.104 & 0.000 & 0.099 & 0.000 & 0.030 & 0.022 & 0.030 & 0.015 & 0.008 \\
\hline $\mathrm{PO}_{4}$ & 1.000 & 1.068 & 1.016 & 1.121 & 0.927 & 0.840 & 0.934 & 0.745 & 1.011 & 1.020 & 0.986 & 1.081 & 0.988 & 0.969 \\
\hline $\mathrm{PO}_{3} \mathrm{OH}$ & 0.707 & 0.460 & 0.518 & 0.492 & 0.727 & 0.767 & 1.056 & 1.039 & 0.421 & 0.371 & 0.396 & 0.283 & 0.474 & 0.292 \\
\hline $\mathrm{SO}_{4}$ & 0.293 & 0.442 & 0.466 & 0.387 & 0.346 & 0.290 & 0.010 & 0.117 & 0.568 & 0.578 & 0.596 & 0.606 & 0.524 & 0.731 \\
\hline$\Sigma X$ & 2.000 & 2.000 & 2.000 & 2.000 & 2.000 & 2.000 & 2.000 & 2.000 & 2.000 & 2.000 & 2.000 & 2.000 & 2.000 & 2.000 \\
\hline$F$ & 0.275 & 0.339 & 0.199 & 0.105 & 1.317 & 0.373 & 1.045 & 1.425 & 0.000 & 0.177 & 0.138 & 0.048 & 0.268 & 0.187 \\
\hline $\mathrm{OH}$ & 6.598 & 5.830 & 5.829 & 6.018 & 5.335 & 6.193 & 5.304 & 5.455 & 6.177 & 5.813 & 6.308 & 5.831 & 5.772 & 6.042 \\
\hline
\end{tabular}




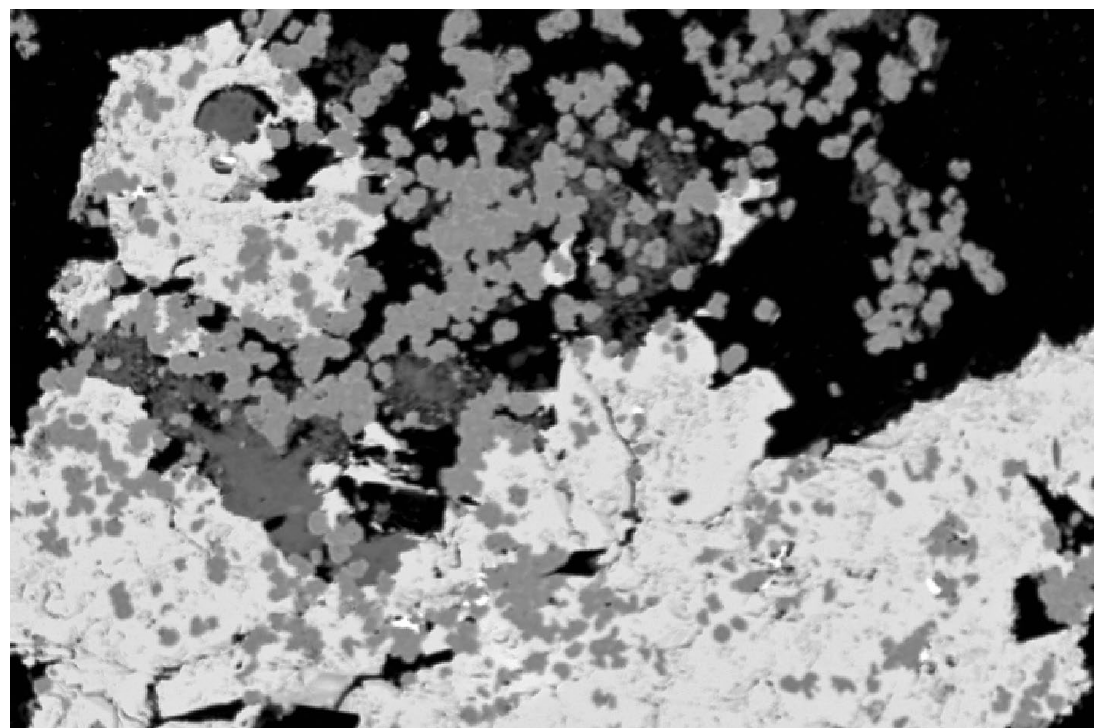

Obr. 31 Agregáty plumbogummitu (šedý) obrůstající a zatlačující agregáty mrázekitu (bilý) v asociaci s pseudomalachitem (tmavě šedý); Hřebečná; šířka záběru $600 \mu \mathrm{m}$, BSE foto J. Sejkora.

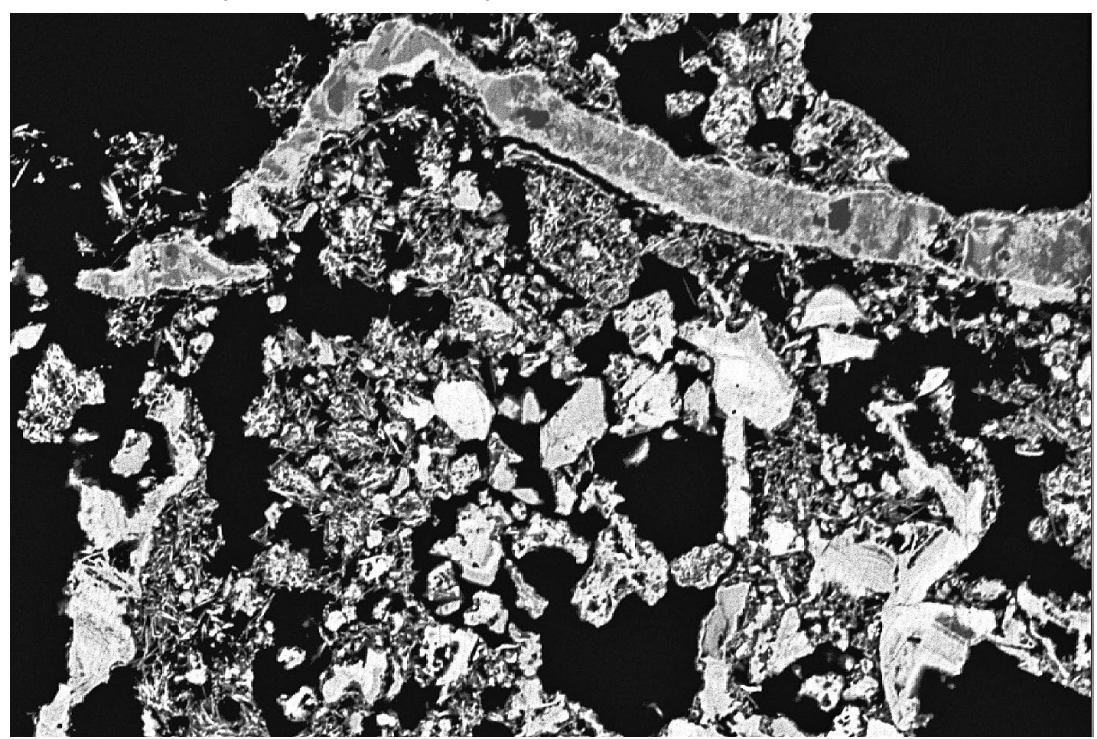

Obr. 32 Výrazně nehomogenní agregáty minerálů superskupiny alunitu; plumbogummit (nejsvětlejši) obrůstá jemně zrnité agregáty crandallitu (šedý), nehomogenní žilka $v$ horní části obrázku je tvořena goyazitem až svanbergitem; Hřebečná; šírka záběru 260 m, BSE foto Z. Dolníček.

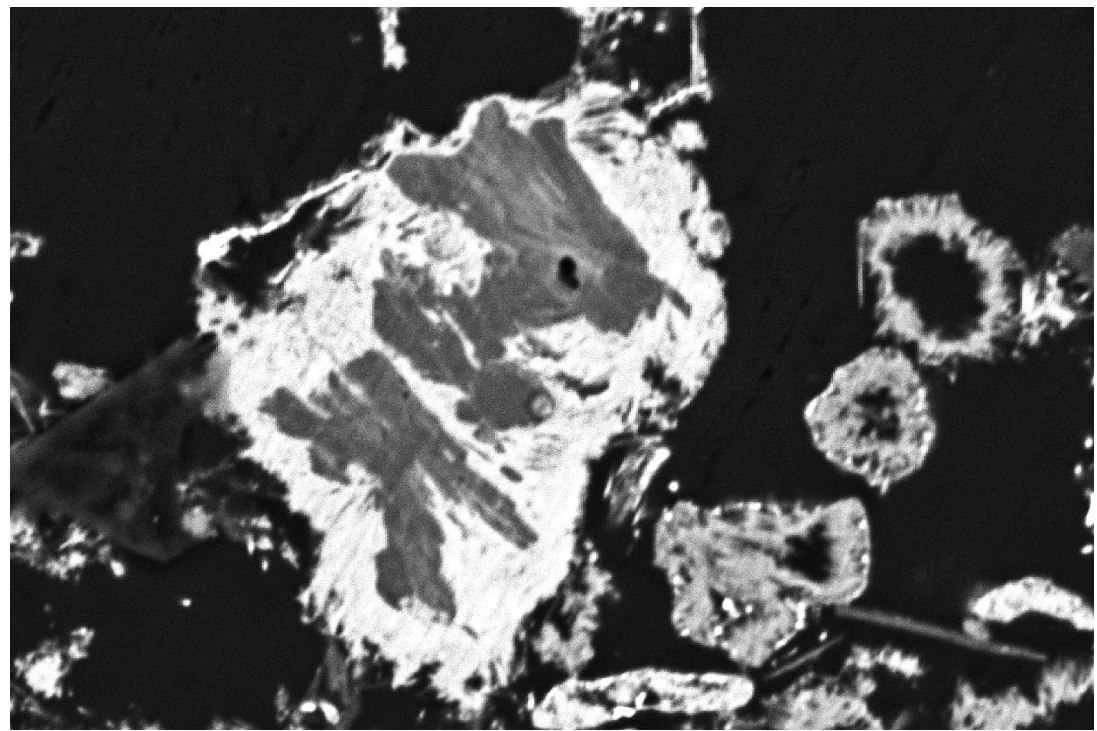

jsou nízké, a až na jeden bod s 0.26 apfu, nepřevyšují hodnotu 0.15 apfu. Proti ostatním členům alunitové superskupiny plumbogummit vykazuje výrazně větší rozsah $\mathrm{FeAl}_{-1}$ izomorfie (do 1.13 apfu Fe, obr. 30) a jen malé zastoupení sulfátové skupiny $v$ aniontu (obr. 29).

Waylandit patří ve studované asociaci ke vzácnějším minerálům alunitové superskupiny. Zjištěn byl jen na jednom vzorku, kde vytváří nepravidelné agregáty o velikosti do $100 \mu \mathrm{m}$ obrůstající starší crandallit (obr. 33) nebo goyazit až svanbergit; $\mathrm{v}$ asociaci vystupuje i pseudomalachit, metatorbernit a dzhalindit. Pro chemické složení waylanditu je charakteristická dominance $\mathrm{Bi} v \mathrm{~A}$-pozici vzorce (0.63 - 0.78 apfu) doprovázeného minoritním zastoupením $\mathrm{Ca}$ (do 0.20 apfu) a Sr (do 0.13 apfu), obsahy $\mathrm{Pb}$ jsou nízké a nepřevyšují 0.05 apfu (obr. 27). V B-pozici je převládající Al doprovázen obsahy Fe (do 0.36 apfu, obr. 30) a zejména až 0.36 apfu $\mathrm{Cu}$, která je $v$ ostatních členech této skupiny z Hřebečné zastoupena jen minimálně. Na rozdíl od ostatních minerálů této skupiny neobsahuje waylandit ani minimální obsahy $\mathrm{S}$ a F (obr. 29).

Crandallit tvoři hojnou součást agregátů minerálů alunitové superskupiny, vytvárí agregáty o velikosti do $0.5 \mathrm{~mm}$ obrůstané mladším goyazitem (obr. 34) nebo lokálně waylanditem (obr. 33); pozorovány byly i tence tabulkovité krystaly crandallitu obrůstané goyazitem a svanbergitem (obr. 35). V A-pozici crandallitu vystupují, vedle převažujícího $\mathrm{Ca}(0.35$ - 0.88 apfu), významněji i Sr (do 0.44 apfu, obr. 26) a Pb (do 0.41 apfu, obr. 28). $V$ jediném agregátu crandallitu byly zjištěny i nevelké (do $10 \mu \mathrm{m}$ ) domény se zvýšeným obsahem gorceixitové složky (do 0.34 apfu Ba). V aniontových pozicích crandallitu byly zjištěny i obsahy S (do 0.48 apfu) a F (do 1.55 apfu, obr. 29).

Poměrně hojný goyazit a svanbergit vytvářejí nehomogenní agre-

Obr. 33 Agregáty waylanditu (bilý) obrůstající zonální tabulky crandallitu (tmavěji šedý) $v$ asociaci s pseudomalachitem (šedý, voštinatý); Hřebečná; šírka záběru $120 \mu \mathrm{m}$, BSE foto Z. Dolníček. 
gáty o velikosti do $100 \mu \mathrm{m}$ (obr. 36), které obrůstají starší tence tabulkovité krystaly (obr. 35) a agregáty crandallitu (obr. 34) a vystupují jako součást nehomogenních agregátů minerálů alunitové superskupiny (obr. 32). Pro jejich chemické složení je charakteristická dominance $\mathrm{Sr} v$ A-pozici (0.36 - 0.95 apfu) doprovázená obsahy $\mathrm{Ca}$ (do 0.44 apfu, obr. 26) a lokálně i $\mathrm{Pb}$ (do 0.29 apfu, obr. 28); zjištěné obsahy Bi jsou minimální (obr. 27). Obsahy sulfátové komponenty $v$ aniontu jsou $u$ goyazitu do $0.47 \mathrm{apfu}$, u svanbergitu pak v rozmezí 0.52 - 0.73 apfu S.

Pseudomalachit tvoří $v$ dutinách alterované žiloviny relativně často drobné zelené až modrozelené kuličkovité agregáty a povlaky o rozměrech do $8 \mathrm{~mm}$. Vyskytuje se $v$ asociaci $s$ libethenitem, vzácněji s mrázekitem (obr. 22 a 23) a s minerály alunitové superskupiny. Rentgenová prášková data pseudomalachitu (tab. 27) odpovídají teoretickým hodnotám vypočteným z krystalové struktury publikované $v$ práci Shoemaker et al. (1981). Zpřesněné parametry jeho základní cely vykazují v porovnání s publikovanými daty (tab. 28) mírně vyšší hodnoty, což je pravděpodobně způsobeno minoritním obsahem As v aniontu (viz níže).

Chemické složení pseudomalachitu z Hřebečné odpovídá vzorci $\mathrm{Cu}_{5}\left(\mathrm{PO}_{4}\right)_{2}(\mathrm{OH})_{4}$ (tab. 29); v kationtu byly vedle převažující $\mathrm{Cu}$ zjištěny minoritní obsahy $\mathrm{Al}$ (do $0.26 \mathrm{apfu}$ ), $\mathrm{Bi}$ (do 0.06 apfu), Zn (do 0.04 apfu) a Fe (do 0.02 apfu). V aniontové části vzorce je dominantní $P$ částečně substituován As (do 0.33 apfu) a ojediněle i V (do 0.02 apfu). Existence úplné izomorfní řady pseudomalachit (P) - cornwallit (As), předpokládaná na základě studia krystalové struktury (Arlt, Armbruster 1999), byla prokázána u vzorků z Krásna (Sejkora et al. 2006; Vrtiška et al. 2016) Medvědína (Plášil et al. 2009), Piesků (Števko, Sejkora 2012, 2014) a Miedzianky (Ciesielczuk et al. 2016).

Obr. 36 Výrazně nehomogenní agregáty crandallitu a svanbergitu (s různými minoritními obsahy $P b$ ) narůstající na fluorapatit (šedý) a křemen (tmavě šedý); Hřebečná; šírka záběru $200 \mu m$, BSE foto Z. Dolníček.

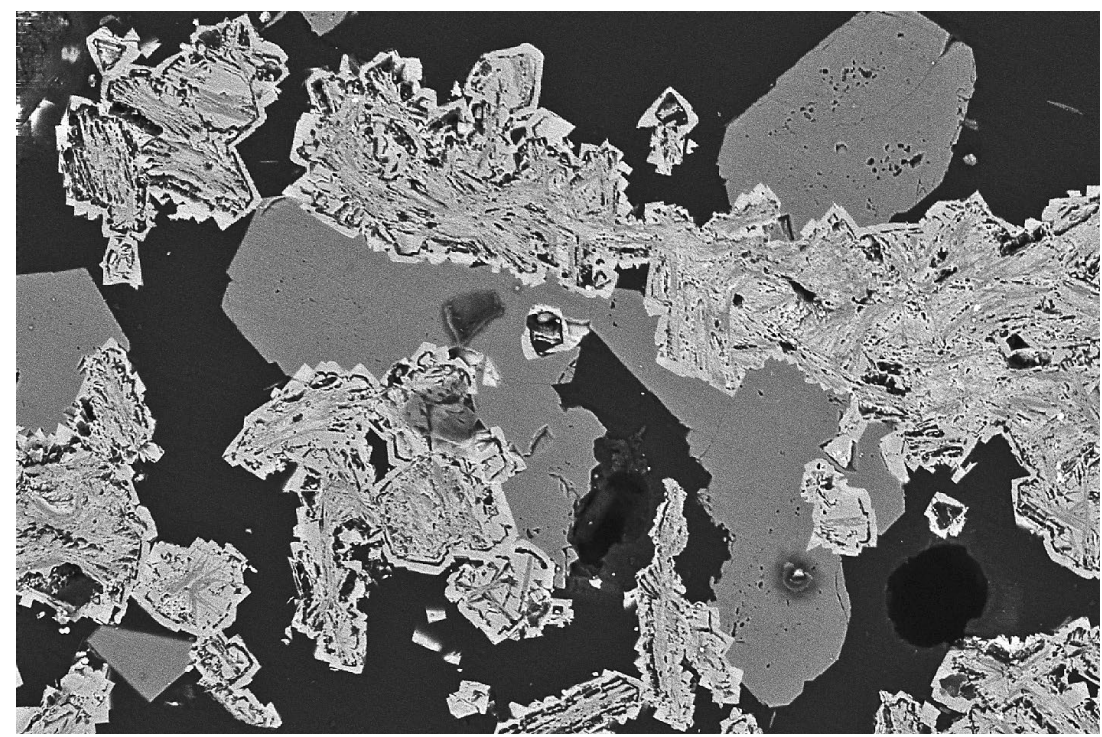

Obr. 34 Krystalické agregáty goyazitu (bílý) obrůstající starší crandallit (šedý) na zrnech křemene (tmavěji šedý); Hřebečná; šířka záběru $600 \mu m$, BSE foto Z. Dolníček.

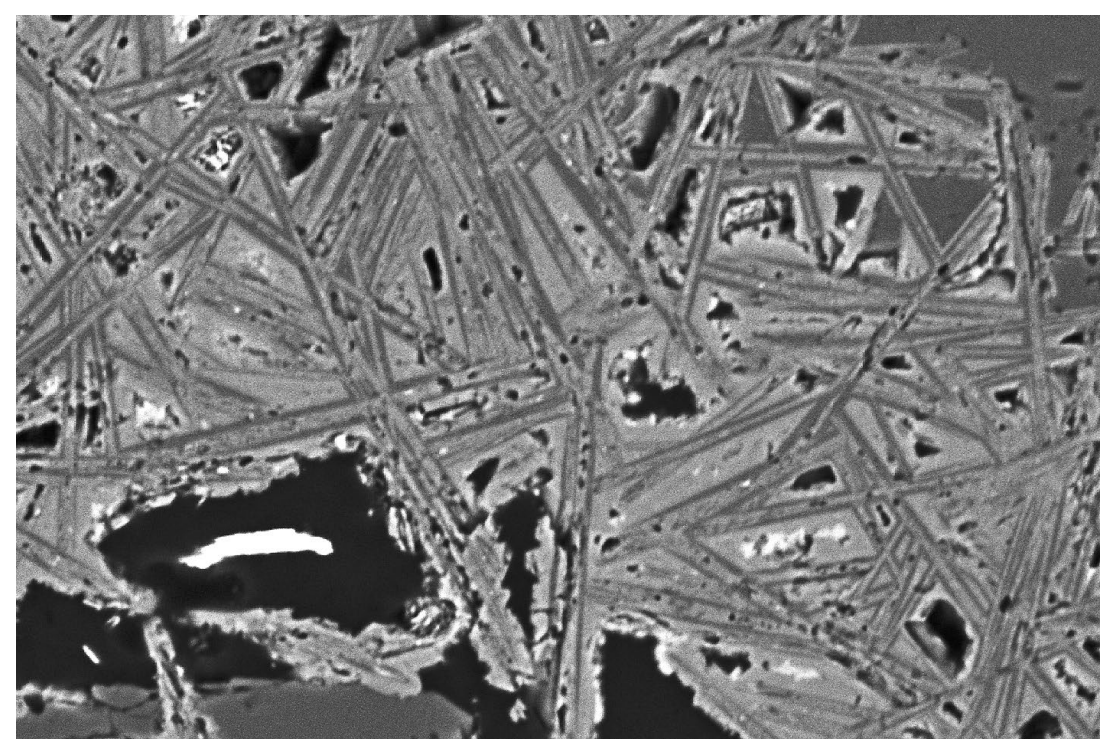

Obr. 35 Tabulkovité agregáty crandallitu (tmavší) obrůstané goyazitem a svanbergitem (světlejší); Hřebečná; šírka záběru $150 \mu \mathrm{m}$, BSE foto Z. Dolníček.

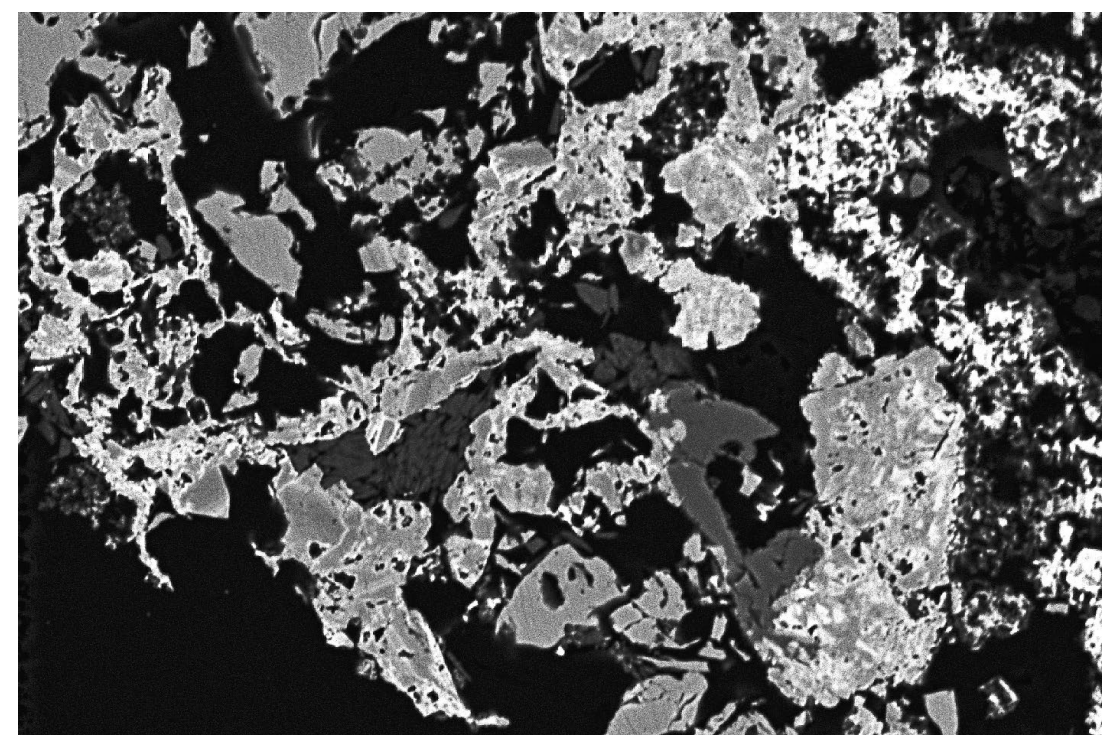


Tabulka 27 Rentgenová prášková data pseudomalachitu z Hřebečné

\begin{tabular}{|c|c|c|c|c|c|c|c|c|c|c|c|c|c|c|c|c|c|}
\hline$I_{o b s .}$ & $d_{o b s .}$ & $d_{\text {calc. }}$ & $h$ & $k$ & 1 & $I_{o b s .}$ & $d_{o b s .}$ & $d_{\text {calc. }}$ & $h$ & $k$ & 1 & $I_{\text {obs. }}$ & $d_{o b s .}$ & $d_{\text {calc. }}$ & $h$ & $k$ & \\
\hline 0.5 & 8.5872 & 8.5547 & 0 & 0 & 2 & 0.9 & 2.7074 & 2.7084 & 1 & 1 & 4 & 1.1 & 1.9535 & 1.9547 & 2 & 1 & 3 \\
\hline 5.7 & 4.7837 & 4.7782 & 0 & 1 & 2 & 2.0 & 2.5720 & 2.5710 & 0 & 2 & 3 & 1.5 & 1.8638 & 1.8636 & 0 & 2 & 7 \\
\hline 100.0 & 4.5058 & 4.4986 & 1 & 0 & 0 & 3.3 & 2.4832 & 2.4822 & 1 & 1 & -5 & 0.5 & 1.8195 & 1.8198 & 0 & 3 & 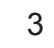 \\
\hline 0.5 & 4.2806 & 4.2773 & 0 & 0 & 4 & 11.2 & 2.4437 & 2.4427 & 1 & 1 & 5 & 2.2 & 7719 & 1.7720 & 2 & 1 & 0 \\
\hline 13.4 & 3.4854 & 3.4829 & 1 & 1 & -1 & 4.7 & 2.4285 & 2.4309 & 1 & 0 & -6 & 3.4 & 1.7419 & 1.7415 & 2 & 2 & -2 \\
\hline 5.5 & 3.4632 & 3.4608 & 1 & 1 & , & 16.4 & 2.3984 & 2.3980 & 1 & 2 & 1 & 2.0 & 1.7311 & 1.7313 & 1 & 2 & -7 \\
\hline 1.4 & 3.4366 & 3.4342 & 0 & 1 & 4 & 5.1 & 2.3407 & 2.3404 & 1 & 2 & -2 & 1.1 & 1.7129 & 1.7124 & 1 & 2 & 7 \\
\hline 2.4 & 3.2958 & 3.2941 & 1 & 1 & -2 & 3 & 2.3272 & 2.3270 & 1 & 2 & 2 & 0.6 & 1.6992 & 1.7006 & 2 & 2 & -3 \\
\hline 9.9 & 3.1327 & 3.1318 & 1 & 0 & -4 & & & 2.2500 & 0 & 1 & 7 & 6.4 & 1.6827 & 1.6832 & 1 & 3 & 3 \\
\hline 9.6 & 3.0713 & 3.0687 & 1 & 0 & 4 & & & 2.2493 & 2 & 0 & 0 & 1.9 & 1.6744 & 1.6746 & 0 & 3 & 5 \\
\hline 2.4 & 3.0367 & 3.0330 & 1 & 1 & -3 & 1.3 & 2.2229 & 2.2234 & 1 & 2 & 3 & 1.3 & 1.6280 & 1.6285 & 2 & 2 & 4 \\
\hline 13.2 & 2.9917 & 2.9897 & 1 & 1 & 3 & 1.7 & 2.2045 & 2.2036 & 0 & 2 & 5 & 1.6 & 1.6056 & 1.6059 & 2 & 1 & -7 \\
\hline 4.2 & 2.9426 & 2.9420 & 0 & 1 & 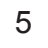 & 1.1 & 2.1392 & 2.1387 & 0 & 0 & 8 & 3.0 & 1.5639 & 1.5639 & 2 & 2 & 5 \\
\hline 3.9 & 2.8811 & 2.8 & 0 & 2 & 0 & 4.4 & 2.1001 & 2.1001 & 1 & 2 & 4 & 1.2 & 36 & 344 & 2 & 0 & \\
\hline 1.0 & 2.8516 & 2.8516 & 0 & 0 & 6 & 1.4 & 2.0272 & 2.0276 & 1 & 1 & -7 & 1.1 & 1.5095 & 1.5100 & 0 & 3 & 7 \\
\hline 0.9 & 2.8409 & 2.8403 & 0 & 2 & 1 & 0.7 & 2.0076 & 2.0077 & 2 & 0 & -4 & 1.6 & 1.4999 & 1.4995 & 3 & 0 & 0 \\
\hline 7.8 & 2.7302 & 2.7297 & 0 & 2 & 2 & 1.0 & 1.9686 & 1.9687 & 1 & 2 & 5 & 0.7 & 1.4708 & 1.4710 & 0 & 2 & 10 \\
\hline
\end{tabular}

Tabulka 28 Parametry základní cely pseudomalachitu (pro monoklinickou prostorovou grupu $P 2, / c$ )

\begin{tabular}{llllll}
\hline & $a[\AA]$ & $b[\AA]$ & $c[\AA]$ & $\beta\left[{ }^{\circ}\right]$ & $V\left[\AA^{3}\right]$ \\
\hline tato práce & $4.4995(7)$ & $5.7606(9)$ & $17.113(2)$ & $91.17(1)$ & $443.47(8)$ \\
Števko et al. (2020) & $4.4805(5)$ & $5.7504(6)$ & $17.045(2)$ & $91.12(1)$ & $439.06(6)$ \\
Toman et al. (2016) & $4.4781(2)$ & $5.7590(2)$ & $17.0278(8)$ & $90.894(4)$ & $439.09(2)$ \\
Števko et al. (2008) & $4.4799(5)$ & $5.7485(7)$ & $17.061(2)$ & $91.13(1)$ & $439.27(6)$ \\
Malý, Sejkora (2004) & $4.484(1)$ & $5.755(1)$ & $17.049(5)$ & $91.11(2)$ & $439.8(1)$ \\
Shoemaker et al. (1977) & $4.4728(4)$ & $5.7469(5)$ & $17.032(3)$ & $91.043(7)$ & 437.7 \\
Ghose (1963) & 4.47 & 5.75 & 17.08 & 91.12 & 438.9 \\
Hutton (1959) & $4.471(5)$ & $5.747(7)$ & $17.02(2)$ & $91.01(8)$ & $437.3(6)$ \\
Berry (1950) & $4.47(1)$ & $5.75(1)$ & $17.01(5)$ & $90.9(2)$ & $436 .(1)$ \\
\hline
\end{tabular}

Tabulka 29 Chemické složení pseudomalachitu z Hřebečné (hm. \%)

\begin{tabular}{lrrrrrrrr}
\hline & mean & 1 & 2 & 3 & 4 & 5 & 6 & 7 \\
\hline $\mathrm{FeO}$ & 0.04 & 0.00 & 0.00 & 0.00 & 0.00 & 0.25 & 0.00 & 0.00 \\
$\mathrm{CuO}$ & 65.09 & 64.87 & 66.97 & 66.33 & 65.49 & 59.35 & 67.27 & 65.37 \\
$\mathrm{ZnO}$ & 0.16 & 0.00 & 0.15 & 0.00 & 0.52 & 0.14 & 0.16 & 0.16 \\
$\mathrm{Al}_{2} \mathrm{O}_{3}$ & 0.61 & 1.07 & 0.27 & 0.00 & 0.33 & 2.13 & 0.11 & 0.34 \\
$\mathrm{Bi}_{2} \mathrm{O}_{3}$ & 0.94 & 0.00 & 0.09 & 0.09 & 1.93 & 2.39 & 0.00 & 1.14 \\
$\mathrm{As}_{2} \mathrm{O}_{5}$ & 2.28 & 3.63 & 3.97 & 0.00 & 1.37 & 6.04 & 0.24 & 0.72 \\
$\mathrm{P}_{2} \mathrm{O}_{5}$ & 22.38 & 22.28 & 22.03 & 24.08 & 23.04 & 18.85 & 23.74 & 22.65 \\
$\mathrm{~V}_{2} \mathrm{O}_{5}$ & 0.04 & 0.00 & 0.28 & 0.00 & 0.00 & 0.00 & 0.00 & 0.00 \\
$\mathrm{H}_{2} \mathrm{O}^{*}$ & 6.15 & 5.92 & 5.95 & 5.86 & 6.25 & 6.34 & 6.24 & 6.36 \\
\hline total & 97.70 & 97.77 & 99.71 & 96.36 & 98.93 & 95.49 & 97.76 & 96.74 \\
\hline $\mathrm{Fe}$ & 0.003 & 0.000 & 0.000 & 0.000 & 0.000 & 0.022 & 0.000 & 0.000 \\
$\mathrm{Cu}$ & 4.876 & 4.721 & 4.838 & 4.915 & 4.893 & 4.690 & 5.026 & 5.051 \\
$\mathrm{Zn}$ & 0.012 & 0.000 & 0.011 & 0.000 & 0.038 & 0.011 & 0.012 & 0.012 \\
$\mathrm{Al}$ & 0.071 & 0.121 & 0.030 & 0.000 & 0.038 & 0.263 & 0.013 & 0.041 \\
$\mathrm{Bi}$ & 0.024 & 0.000 & 0.002 & 0.002 & 0.049 & 0.064 & 0.000 & 0.030 \\
$\mathrm{As}$ & 0.118 & 0.183 & 0.199 & 0.000 & 0.071 & 0.330 & 0.012 & 0.039 \\
$\mathrm{P}$ & 1.879 & 1.817 & 1.784 & 2.000 & 1.929 & 1.670 & 1.988 & 1.961 \\
$\mathrm{~V}$ & 0.003 & 0.000 & 0.018 & 0.000 & 0.000 & 0.000 & 0.000 & 0.000 \\
$\mathrm{OH}$ & 4.068 & 3.806 & 3.796 & 3.838 & 4.124 & 4.427 & 4.113 & 4.339 \\
\hline
\end{tabular}

mean - průměr ze sedmi bodových analýz; koeficienty empirických vzorců počíány na bázi As+P+V= 2 apfu; $\mathrm{H}_{2} \mathrm{O}^{*}$ obsah dopočtený na základě vyrovnání náboje. 
Empirický vzorec pseudomalachitu (průměr sedmi bodových analýz) je možno na bázi $\mathrm{P}+\mathrm{As}+\mathrm{V}=2$ apfu vyjádřit jako $\left(\mathrm{Cu}_{4.88} \mathrm{Al}_{0.07} \mathrm{Bi}_{0.02} \mathrm{Zn}_{0.01}\right)_{\Sigma 4.98}\left(\mathrm{PO}_{4}\right)_{1.88}\left(\mathrm{AsO}_{4}\right)_{0.12}(\mathrm{OH})_{4.07}$.

Libethenit byl zjištěn jen vzácně jako drobně modrozelené jehličkovité agregáty o délce do $3 \mathrm{~mm}$, které většinou těsně asociuji s pseudomalachitem. Rentgenová prášková data (tab. 30) odpovídají teoretickým hodnotám vypočteným z krystalové struktury publikované $v$ práci Yakubovich et al. (1993). Zpřesněné parametry základní cely jsou $v$ tabulce 31 porovnány s publikovanými daty pro tuto minerální fázi

Při studiu chemického složení (tab. 32) byly v kationtové pozici zjištěny vedle $\mathrm{Cu}$ i minoritní obsahy $\mathrm{Fe}$ (do 0.09 apfu), Al (do 0.08 apfu) a Bi, Zn (do 0.03 apfu).

Tabulka 30 Rentgenová prášková data libethenitu z Hřebečné

\begin{tabular}{|c|c|c|c|c|c|c|c|c|c|c|c|c|c|c|c|c|c|}
\hline$I_{\text {obs. }}$ & $d_{o b s .}$ & $d_{\text {calc. }}$ & $h$ & $k$ & I & $I_{\text {obs. }}$ & $d_{o b s .}$ & $d_{\text {calc. }}$ & $h$ & $k$ & I & $I_{\text {obs. }}$ & $d_{o b s .}$ & $d_{\text {calc. }}$ & $h$ & $k$ & \\
\hline 100.0 & 5.8344 & 5.8317 & 1 & 1 & 0 & 5.0 & 2.6139 & 2.6135 & 2 & 2 & 1 & 2.3 & 2.2703 & 2.2703 & 3 & 2 & 0 \\
\hline 19.1 & 4.8297 & 4.8273 & 0 & 1 & 1 & 17.6 & 2.5677 & 2.5681 & 3 & 1 & 0 & 0.9 & 2.0722 & 2.0727 & 2 & 2 & 2 \\
\hline 14.7 & 4.7648 & 4.7637 & 1 & 0 & 1 & 1.5 & 2.5321 & 2.5325 & 0 & 3 & 1 & 1.2 & 1.9439 & 1.9439 & 3 & 3 & 0 \\
\hline 1.5 & 4.1466 & 4.1454 & 1 & 1 & 1 & 10.3 & 2.4517 & 2.4522 & 3 & 0 & 1 & 1.2 & 1.9372 & 1.9361 & 3 & 1 & \\
\hline 16.1 & 3.7339 & 3.7325 & 1 & 2 & 0 & 5.9 & 2.4166 & 2.4169 & 1 & 3 & 1 & 0.6 & 1.9245 & 1.9242 & 1 & 4 & \\
\hline 12.9 & 3.6458 & 3.6457 & 2 & 1 & 0 & 3.5 & 2.3815 & 2.3819 & 2 & 0 & 2 & 2.1 & 1.8651 & 1.8654 & 4 & 1 & \\
\hline 73.6 & 2.9165 & 2.9159 & 2 & 2 & 0 & 3.8 & 2.3549 & 2.3543 & 3 & 1 & 1 & 0.9 & 1.7982 & 1.7985 & 3 & 2 & 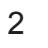 \\
\hline 5.9 & 2.6486 & 2.6499 & 1 & 3 & 0 & 8.8 & 2.3122 & 2.3129 & 1 & 2 & 2 & 2.1 & 1.7124 & 1.7121 & 0 & 4 & \\
\hline 12.6 & 2.6299 & 2.6302 & 1 & 1 & 2 & & & & & & & & & & & & \\
\hline
\end{tabular}

Tabulka 31 Parametry základní cely libethenitu (pro ortorombickou prostorovou grupu Pnnm)

\begin{tabular}{|c|c|c|c|c|c|}
\hline & & $a[\AA]]$ & $b[\AA]]$ & $c[\AA]$ & $V\left[\AA^{3}\right]$ \\
\hline tato práce & Hřebečná & $8.0902(10)$ & $8.4139(11)$ & $5.8938(11)$ & $401.20(6)$ \\
\hline Števko et al. (2017) & L’ubietová - Podlipa & $8.062(1)$ & $8.393(2)$ & $5.885(1)$ & $398.2(1)$ \\
\hline Števko et al. (2017) & L’ubietová - Rainer & $8.066(1)$ & $8.396(1)$ & $5.8866(9)$ & $398.6(1)$ \\
\hline Števko et al. (2017) & L’ubietová - Podlipa & $8.069(2)$ & $8.397(1)$ & $5.8857(4)$ & $398.8(1)$ \\
\hline Števko et al. (2017) & L'ubietová -, Rainer & $8.064(1)$ & 8.394(1) & $5.887(1)$ & $398.5(1)$ \\
\hline Števko et al. (2017) & L’ubietová - Podlipa & $8.286(1)$ & $8.279(1)$ & $5.903(1)$ & $404.9(2)$ \\
\hline Števko et al. (2017) & L’ubietová - Rainer & $8.071(1)$ & $8.399(1)$ & $5.886(1)$ & $399.02(2)$ \\
\hline Števko et al. (2017) & L’ubietová - Rainer & $8.065(1)$ & $8.392(1)$ & $5.894(1)$ & $398.9(1)$ \\
\hline Cordsen (1978) & L’ubietová & $8.071(2)$ & $8.403(4)$ & $5.898(3)$ & 400.01 \\
\hline Zema et al. (2011) & L’ubietová & $8.0614(2)$ & $8.3972(2)$ & $5.8870(1)$ & $398.51(2)$ \\
\hline Lafuente et al. (2015) & L'ubietová & $8.0623(3)$ & $8.4001(4)$ & $5.8892(2)$ & $398.84(2)$ \\
\hline
\end{tabular}

Tabulka 32 Chemické složení libethenitu z Hřebečné (hm. \%)

\begin{tabular}{lrrrrrrrr}
\hline \multicolumn{1}{c}{ mean } & 1 & 2 & 3 & 4 & 5 & 6 & 7 \\
\hline $\mathrm{FeO}$ & 0.58 & 0.28 & 0.32 & 1.03 & 0.00 & 0.00 & 0.00 & 2.41 \\
$\mathrm{CuO}$ & 62.22 & 63.03 & 58.23 & 59.67 & 62.64 & 64.68 & 66.88 & 60.43 \\
$\mathrm{ZnO}$ & 0.35 & 1.19 & 0.00 & 1.03 & 0.20 & 0.00 & 0.00 & 0.00 \\
$\mathrm{Al}_{2} \mathrm{O}_{3}$ & 0.59 & 0.00 & 1.69 & 0.00 & 0.33 & 0.80 & 0.54 & 0.75 \\
$\mathrm{Bi}_{2} \mathrm{O}_{3}$ & 0.98 & 0.38 & 1.56 & 0.93 & 2.43 & 0.04 & 0.01 & 1.48 \\
$\mathrm{As}_{2} \mathrm{O}_{5}$ & 7.28 & 2.26 & 8.33 & 12.03 & 8.28 & 9.81 & 8.73 & 1.49 \\
$\mathrm{P}_{2} \mathrm{O}_{5}$ & 24.21 & 29.95 & 24.32 & 21.76 & 23.21 & 21.74 & 22.81 & 25.66 \\
$\mathrm{~V}_{2} \mathrm{O}_{5}$ & 0.08 & 0.00 & 0.00 & 0.00 & 0.00 & 0.53 & 0.00 & 0.00 \\
$\mathrm{H}_{2} \mathrm{O}^{*}$ & 3.79 & 2.75 & 3.13 & 2.99 & 3.90 & 4.34 & 4.70 & 4.74 \\
\hline total & 100.06 & 99.84 & 97.58 & 99.44 & 100.99 & 101.94 & 103.67 & 96.96 \\
\hline $\mathrm{Fe}$ & 0.020 & 0.009 & 0.011 & 0.035 & 0.000 & 0.000 & 0.000 & 0.090 \\
$\mathrm{Cu}$ & 1.930 & 1.794 & 1.763 & 1.824 & 1.973 & 2.046 & 2.116 & 2.028 \\
$\mathrm{Zn}$ & 0.010 & 0.033 & 0.000 & 0.031 & 0.006 & 0.000 & 0.000 & 0.000 \\
$\mathrm{Al}$ & 0.028 & 0.000 & 0.080 & 0.000 & 0.016 & 0.039 & 0.027 & 0.039 \\
$\mathrm{Bi}$ & 0.010 & 0.004 & 0.016 & 0.010 & 0.026 & 0.000 & 0.000 & 0.017 \\
$\mathrm{As}$ & 0.156 & 0.045 & 0.175 & 0.255 & 0.181 & 0.215 & 0.191 & 0.035 \\
$\mathrm{P}$ & 0.842 & 0.955 & 0.825 & 0.745 & 0.819 & 0.771 & 0.809 & 0.965 \\
$\mathrm{~V}$ & 0.002 & 0.000 & 0.000 & 0.000 & 0.000 & 0.015 & 0.000 & 0.000 \\
$\mathrm{OH}$ & 1.038 & 0.691 & 0.836 & 0.808 & 1.086 & 1.211 & 1.312 & 1.405 \\
\hline
\end{tabular}

mean - průměr ze sedmi bodových analýz; koeficienty empirických vzorců počítány na bázi $A s+P+V=1 a p f u ; \mathrm{H}_{2} \mathrm{O}^{*}-$ obsah dopočtený na základě vyrovnání náboje. 
Tabulka 33 Chemické složení dzhalinditu z Hřebečné (hm. \%)

\begin{tabular}{lrrrrr}
\hline & mean & 1 & 2 & 3 & 4 \\
\hline $\mathrm{CuO}$ & 1.81 & 1.22 & 2.11 & 2.12 & 1.77 \\
$\mathrm{Fe}_{2} \mathrm{O}_{3}$ & 3.61 & 5.58 & 4.05 & 4.02 & 0.78 \\
$\mathrm{Al}_{2} \mathrm{O}_{3}$ & 0.28 & 0.12 & 0.00 & 0.67 & 0.32 \\
$\mathrm{In}_{2} \mathrm{O}_{3}$ & 73.67 & 73.75 & 73.69 & 73.03 & 74.21 \\
$\mathrm{H}_{2} \mathrm{O}^{*}$ & 16.12 & 16.59 & 16.19 & 16.42 & 15.28 \\
\hline total & 95.12 & 96.70 & 95.63 & 95.86 & 92.28 \\
\hline $\mathrm{Fe}$ & 0.075 & 0.113 & 0.083 & 0.082 & 0.017 \\
$\mathrm{Cu}$ & 0.038 & 0.025 & 0.044 & 0.043 & 0.039 \\
$\mathrm{Al}$ & 0.009 & 0.004 & 0.000 & 0.021 & 0.011 \\
$\mathrm{In}$ & 0.879 & 0.859 & 0.873 & 0.854 & 0.933 \\
$\mathrm{OH}$ & 2.962 & 2.975 & 2.956 & 2.957 & 2.961 \\
\hline $\mathrm{mean}$ & & & &
\end{tabular}

mean - průměr ze čtyř bodových analýz; koeficienty empirických vzorců počítány na bázi sumy kationtů $=1 \mathrm{apfu} ; \mathrm{H}_{2} \mathrm{O}^{*}$ - obsah dopočtený na základě vyrovnání náboje.
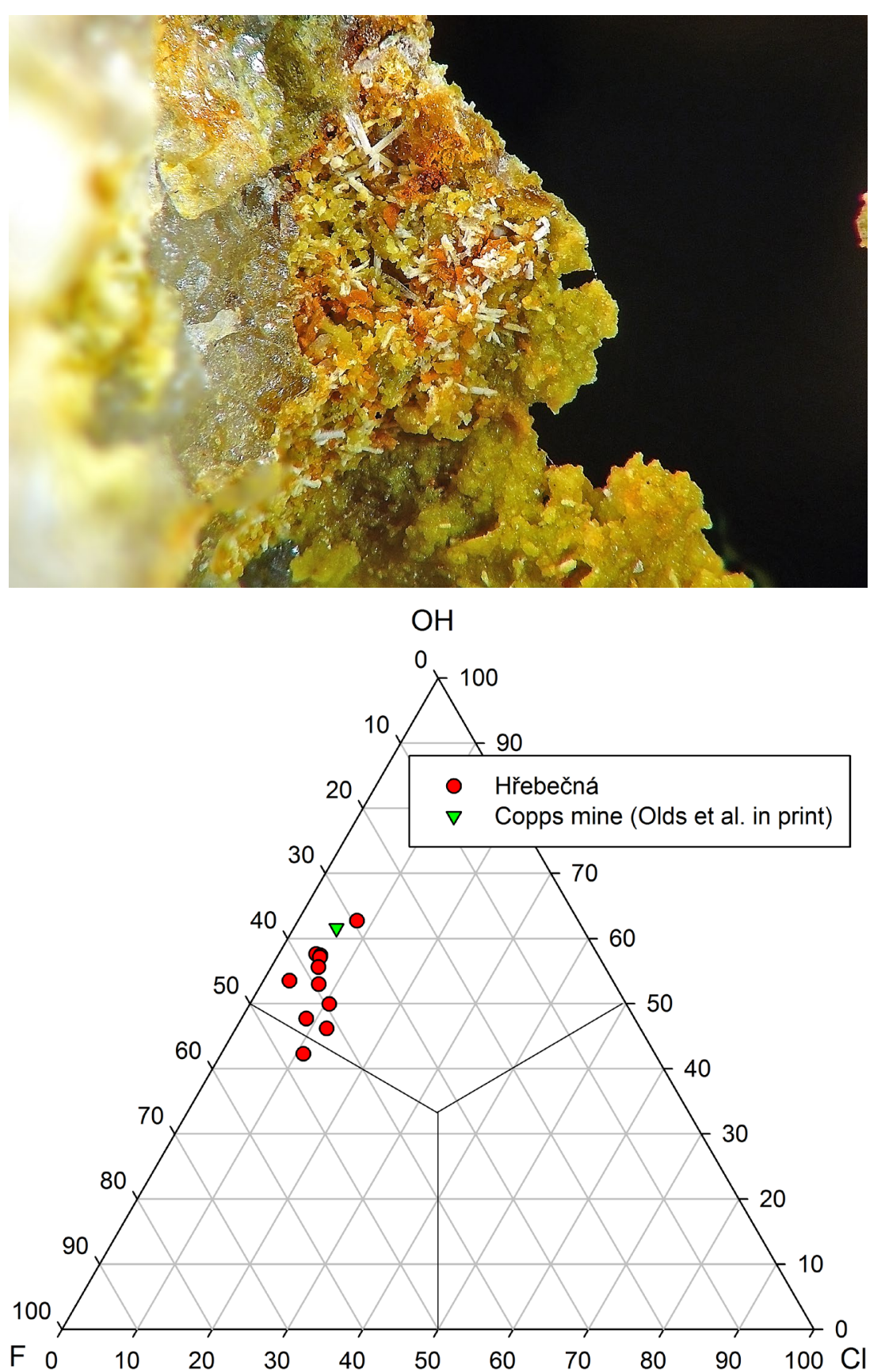

$\checkmark$ aniontové pozici je pak $\mathrm{P}$ substituován As (do 0.25 apfu) a ojediněle i V (do 0.01 apfu); široká izomorfie mezi libethenitem $(P)$ a olivenitem (As) je dobře známa (např. Sejkora et al. 2006; Števko, Sejkora 2014; Vrtiška et al. 2016). Průměrný empirický vzorec (sedm bodových analýz) libethenitu (na bázi $\mathrm{P}+\mathrm{As}+\mathrm{V}=1 \mathrm{apfu}$ ) je $\quad\left(\mathrm{Cu}_{1.93} \mathrm{Al}_{0.03} \mathrm{Fe}_{0.02} \mathrm{Bi}_{0.01} \mathrm{Zn}_{0.01}\right)_{\Sigma 2.00}(\mathrm{P}$ $\left.\mathrm{O}_{4}\right)_{0.84}\left(\mathrm{AsO}_{4}\right)_{0.16}(\mathrm{OH})_{1.04}$.

Dzhalindit byl zjištěn jen ojediněle jako mikroskopická nepravidelná zrna o velikosti do $12 \mu \mathrm{m}$ zarůstající do nehomogenních agregátů crandallitu a waylanditu. Při studiu jeho chemického složení (tab. 33) byly vedle dominantního In zjištěny minoritní obsahy Fe (do 0.11 apfu), Cu (do 0.04 apfu) a Al (do 0.02 apfu). Průměrný empirický vzorec (čtyři bodové analýzy) je možno vyjádřit jako ( $\ln _{0.88}$ $\left.\mathrm{Fe}_{0.07} \mathrm{Cu}_{0.04} \mathrm{Al}_{0.01}\right)_{\Sigma 1.00}(\mathrm{OH})_{2.96}$.

Hydroxylpyromorfit vytváří velmi vzácně průsvitné bílé sloupečkovité krystaly s hexagonálním prưřezem o délce do $50 \mu \mathrm{m}$ narůstající na agregáty plumbogummitu $s$ variabilními poměry $\mathrm{Al} / \mathrm{Fe}$ (obr. 37). Ojediněle byly zjištěny i jeho nedokonalé krystaly stejného habitu o délce do 200 $\mu \mathrm{m}$ zarůstající do plumbogummitu.

Chemické složení minerálů skupiny pyromorfitu z Hřebečné odpovídá, až na jeden analyzovaný bod (tab. 34), recentně definovanému novému druhu - hydroxylpyromorfitu (Olds et al. in print), u kterého $v \mathrm{Cl}+\mathrm{F}+\mathrm{OH}$ pozici, na rozdíl od obecně zcela převládajícího chlorpyromorfitu, převládá hydroxylová skupina (obr. 38). Jedna bodová analýza (analýza $10 \mathrm{v}$ tabulce 34) již odpovídá dosud nepopsanému F-dominantnímu fluorpyromorfitu.

$\mathrm{V}$ kationtových pozicích je $\mathrm{Pb}$ doprovázeno minoritními obsahy $\mathrm{Ca}$ (do 0.24 apfu), Zn (do 0.05 apfu) a Fe (do 0.04 apfu). Nevelký přebytek celkového obsazení kationtových pozic (5.01 - 5.35 apfu) může naznačovat minoritní prítomnost $\left(\mathrm{CO}_{3}\right)^{2-}$ skupiny

Obr. 37 Bilé krystaly hydroxylpyromorfitu narůstající na agregáty plumbogummitu s různými poměry Al/Fe; Hřebečná; šířka záběru $1 \mathrm{~mm}$, foto P. Fuchs.

Obr. 38 Ternární graf $\mathrm{Cl}$ - $\mathrm{OH}$ - $\mathrm{F}$ (at. jednotky) pro pyromorfit z Hřebečné. 
Tabulka 34 Chemické složení minerálů skupiny pyromorfitu z Hřebečné (hm. \%)

\begin{tabular}{|c|c|c|c|c|c|c|c|c|c|c|c|}
\hline & mean & 1 & 2 & 3 & 4 & 5 & 6 & 7 & 8 & 9 & 10 \\
\hline$\overline{\mathrm{CaO}}$ & 0.80 & 0.55 & 1.01 & 0.84 & 0.91 & 0.92 & 0.72 & 0.69 & 0.86 & 0.84 & 0.66 \\
\hline $\mathrm{FeO}$ & 0.17 & 0.11 & 0.20 & 0.23 & 0.12 & 0.12 & 0.19 & 0.12 & 0.21 & 0.23 & 0.14 \\
\hline $\mathrm{PbO}$ & 81.10 & 80.27 & 80.57 & 81.28 & 81.70 & 81.03 & 81.50 & 80.29 & 82.20 & 79.54 & 82.60 \\
\hline $\mathrm{ZnO}$ & 0.15 & 0.26 & 0.26 & 0.27 & 0.28 & 0.29 & 0.00 & 0.00 & 0.00 & 0.16 & 0.00 \\
\hline $\mathrm{P}_{2} \mathrm{O}_{5}$ & 15.56 & 15.02 & 15.69 & 15.62 & 15.51 & 16.15 & 15.67 & 15.68 & 15.26 & 15.91 & 15.11 \\
\hline $\mathrm{SO}_{3}{ }^{5}$ & 0.14 & 0.25 & 0.11 & 0.08 & 0.08 & 0.04 & 0.25 & 0.20 & 0.14 & 0.01 & 0.26 \\
\hline $\mathrm{Cl}^{3}$ & 0.20 & 0.20 & 0.15 & 0.15 & 0.13 & 0.17 & 0.28 & 0.32 & 0.09 & 0.23 & 0.28 \\
\hline $\mathrm{F}$ & 0.55 & 0.40 & 0.52 & 0.52 & 0.52 & 0.55 & 0.56 & 0.59 & 0.59 & 0.62 & 0.64 \\
\hline $\mathrm{H}_{2} \mathrm{O}^{*}$ & 0.35 & 0.40 & 0.38 & 0.38 & 0.38 & 0.38 & 0.34 & 0.31 & 0.35 & 0.32 & 0.27 \\
\hline $\mathrm{O}=\mathrm{F}$ & -0.23 & -0.17 & -0.22 & -0.22 & -0.22 & -0.23 & -0.24 & -0.25 & -0.25 & -0.26 & -0.27 \\
\hline $\mathrm{O}=\mathrm{Cl}$ & -0.05 & -0.05 & -0.03 & -0.03 & -0.03 & -0.04 & -0.06 & -0.07 & -0.02 & -0.05 & -0.06 \\
\hline total & 98.74 & 97.25 & 98.64 & 99.12 & 99.38 & 99.38 & 99.21 & 97.88 & 99.43 & 97.55 & 99.63 \\
\hline$\overline{\mathrm{Ca}}$ & 0.194 & 0.137 & 0.243 & 0.203 & 0.222 & 0.216 & 0.172 & 0.165 & 0.212 & 0.200 & 0.163 \\
\hline $\mathrm{Fe}$ & 0.032 & 0.021 & 0.038 & 0.043 & 0.023 & 0.022 & 0.035 & 0.022 & 0.040 & 0.043 & 0.027 \\
\hline $\mathrm{Pb}$ & 4.932 & 5.024 & 4.869 & 4.942 & 5.002 & 4.776 & 4.892 & 4.830 & 5.097 & 4.767 & 5.137 \\
\hline $\mathrm{Zn}$ & 0.025 & 0.045 & 0.043 & 0.045 & 0.047 & 0.047 & 0.000 & 0.000 & 0.000 & 0.026 & 0.000 \\
\hline $\bar{\Sigma}$ & 5.182 & 5.227 & 5.192 & 5.233 & 5.294 & 5.061 & 5.100 & 5.018 & 5.350 & 5.036 & 5.327 \\
\hline $\bar{P}$ & 2.976 & 2.956 & 2.981 & 2.986 & 2.986 & 2.993 & 2.958 & 2.966 & 2.976 & 2.998 & 2.955 \\
\hline S & 0.024 & 0.044 & 0.019 & 0.014 & 0.014 & 0.007 & 0.042 & 0.034 & 0.024 & 0.002 & 0.045 \\
\hline $\bar{\Sigma}$ & 3.000 & 3.000 & 3.000 & 3.000 & 3.000 & 3.000 & 3.000 & 3.000 & 3.000 & 3.000 & 3.000 \\
\hline$\overline{\mathrm{Cl}}$ & 0.077 & 0.079 & 0.057 & 0.057 & 0.050 & 0.063 & 0.106 & 0.121 & 0.035 & 0.087 & 0.110 \\
\hline $\mathrm{F}$ & 0.394 & 0.294 & 0.369 & 0.371 & 0.374 & 0.381 & 0.395 & 0.417 & 0.430 & 0.436 & 0.468 \\
\hline $\mathrm{OH}$ & 0.527 & 0.620 & 0.569 & 0.572 & 0.576 & 0.555 & 0.506 & 0.462 & 0.538 & 0.475 & 0.416 \\
\hline $\bar{\Sigma}$ & 0.998 & 0.993 & 0.995 & 1.001 & 1.001 & 0.999 & 1.006 & 1.000 & 1.003 & 0.998 & 0.993 \\
\hline
\end{tabular}

mean - průměr z 10 bodových analýz; koeficienty empirických vzorců počítány na bázi $\mathrm{P}+\mathrm{S}=3$ apfu; $\mathrm{H}_{2} \mathrm{O}^{*}-$ obsah dopočtený na základě ideálního obsahu $\mathrm{F}+\mathrm{Cl}+\mathrm{OH}=1$ apfu.

Obr. 39 Tabulkovité agregáty metatorbernitu (bílý) srůstající s jehlicemi mixitu (šedý); Hřebečná; šiřka záběru $400 \mu \mathrm{m}$, BSE foto Z. Dolníček.

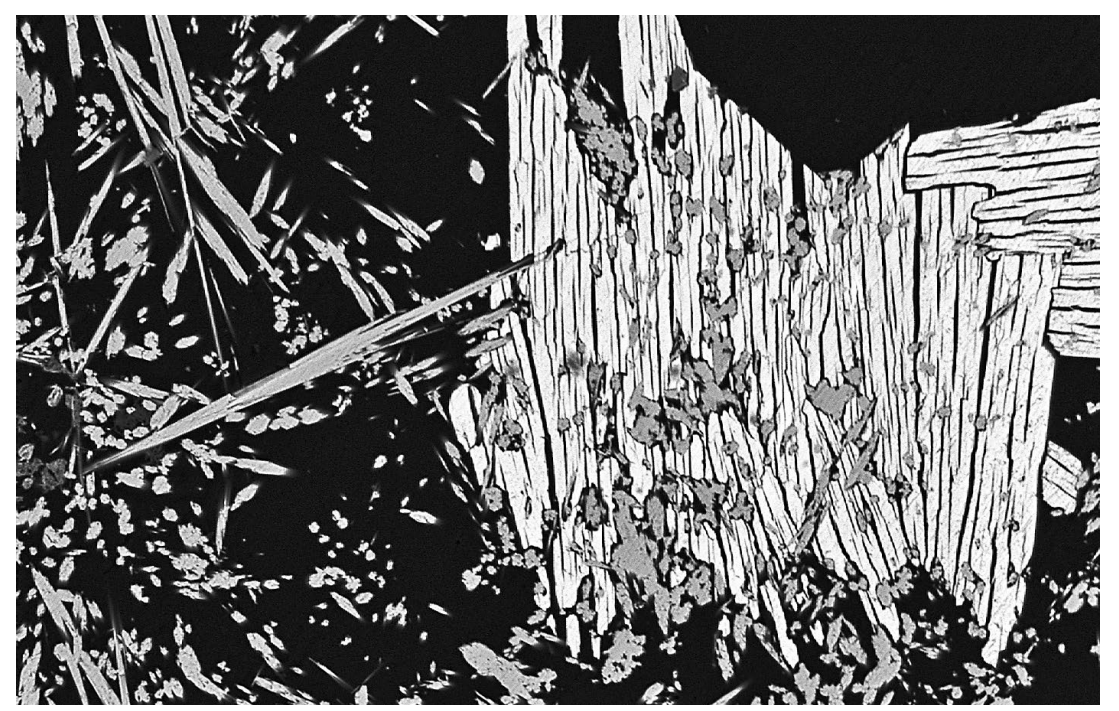

Obr. 40 Tabulkovité agregáty metatorbernitu (bilý) narùstající na tabulkovité agregáty crandallitu (tmavši) obrůstané goyazitem a svanbergitem (světlejši); Hřebečná; šírka záběru $600 \mu \mathrm{m}, \mathrm{BSE}$ foto Z. Dolníček.

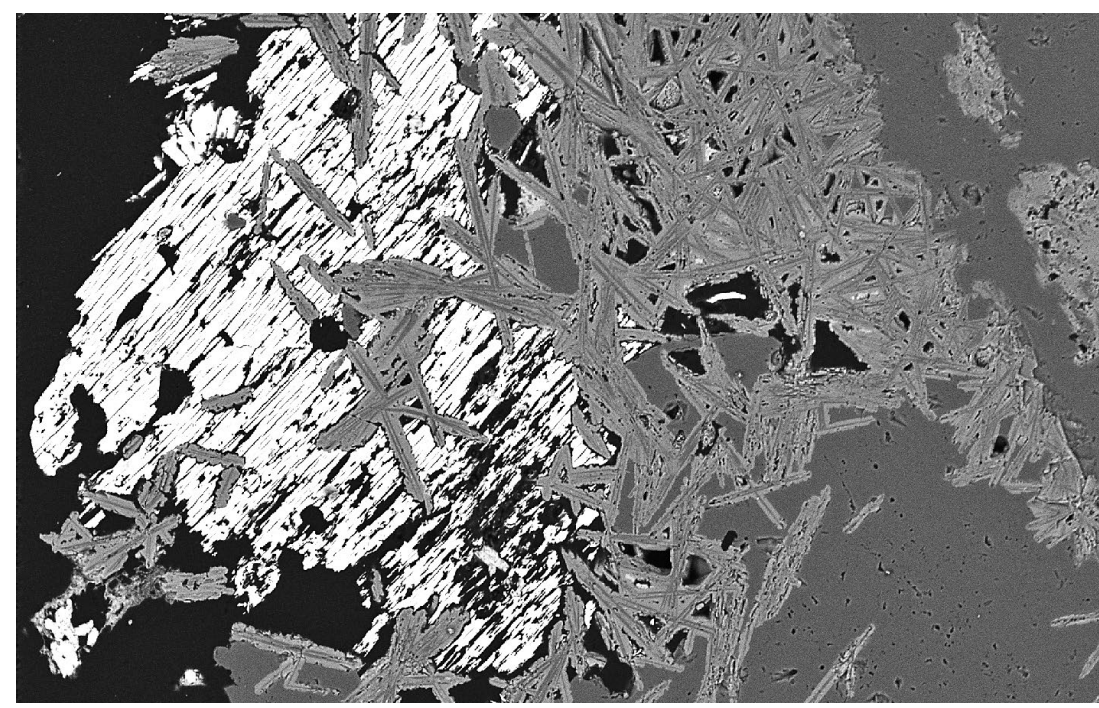


Tabulka 35 Chemické složení metatorbernitu z Hřebečné (hm. \%)

\begin{tabular}{lrrrrrr}
\hline & mean & 1 & 2 & 3 & 4 & 5 \\
\hline $\mathrm{CuO}$ & 7.63 & 8.03 & 8.22 & 7.93 & 6.61 & 7.35 \\
$\mathrm{As}_{2} \mathrm{O}_{5}$ & 4.59 & 3.67 & 8.52 & 3.76 & 3.55 & 3.44 \\
$\mathrm{P}_{2} \mathrm{O}_{5}$ & 12.23 & 12.40 & 8.84 & 13.98 & 12.64 & 13.31 \\
$\mathrm{UO}_{3}$ & 59.92 & 59.17 & 60.22 & 60.61 & 59.94 & 59.67 \\
$\mathrm{H}_{2} \mathrm{O}^{*}$ & 15.30 & 14.89 & 14.31 & 16.55 & 15.06 & 15.67 \\
\hline total & 99.67 & 98.17 & 100.10 & 102.83 & 97.81 & 99.43 \\
\hline $\mathrm{Cu}$ & 0.904 & 0.978 & 1.040 & 0.868 & 0.795 & 0.850 \\
$\mathrm{As}$ & 0.376 & 0.309 & 0.746 & 0.285 & 0.296 & 0.275 \\
$\mathrm{P}$ & 1.624 & 1.691 & 1.254 & 1.715 & 1.704 & 1.725 \\
$\mathrm{U}$ & 1.974 & 2.002 & 2.120 & 1.845 & 2.005 & 1.919 \\
$\mathrm{H}_{2} \mathrm{O}$ & 8 & 8 & 8 & 8 & 8 & 8 \\
\hline
\end{tabular}

mean - průměr z pěti bodových analýz; koeficienty empirických vzorců počítány na bázi As+P $=2$ apfu; $\mathrm{H}_{2} \mathrm{O}^{*}$ obsah dopočtený na základě teoretického obsahu $8 \mathrm{H}_{2} \mathrm{O}$ $v$ metatorbernitu.

$v$ aniontu. Průměrné složení studovaného minerálu z Hřebečné je možno na bázi $\mathrm{P}+\mathrm{S}=3$ apfu vyjádřit empirickým vzorcem $\left(\mathrm{Pb}_{4.93} \mathrm{Ca}_{0.19} \mathrm{Fe}_{0.03} \mathrm{Zn}_{0.03}\right)_{\Sigma 5.18}\left[\left(\mathrm{PO}_{4}\right)_{2.98}\left(\mathrm{SO}_{4}\right)_{0.02}\right]_{\Sigma 3.00}$ $\left[(\mathrm{OH})_{0.53} \mathrm{~F}_{0.39} \mathrm{Cl}_{0.08}\right]_{\Sigma 1.00}$.

Metatorbernit byl zjištěn jako jasně zelené nepravidelné tabulkovité agregáty se zřetelnou štěpností o velikosti do $0.5 \mathrm{~mm} v$ asociaci s jehlicovitým mixitem (obr. 39) nebo lupenitým crandallitem obrůstaným goyazitem a svanbergitem (obr. 40). Chemickou analýzou (tab. 35) byly vedle $\mathrm{Cu}, \mathrm{U}$ a $\mathrm{P}$ zjištěny i obsahy As (metazeuneritové komponenty) v rozmezí $0.28-0.75$ apfu. Průměrný empirický vzorec (pět bodových analýz) metatorbernitu z Hřebečné je možno na bázi $\mathrm{P}+\mathrm{As}=2$ apfu vyjádřit jako $\mathrm{Cu}_{0.90}\left(\mathrm{UO}_{2}\right)_{1.97}\left(\mathrm{PO}_{4}\right)_{1.62}\left(\mathrm{AsO}_{4}\right)_{0.38} \cdot 8 \mathrm{H}_{2} \mathrm{O}$.

\section{Diskuse a závěr}

Drobný, ale mineralogicky mimořádně pestrý (více než 35 zjištěných minerálních fází) výskyt křemenné greisenové mineralizace, zjištěný $v$ haldovém materiálu dolu Mauritius v Hřebečné u Abertam, se svým texturním i mineralogickým charakterem výrazně liší od obvyklého zrudnění jemnozrnných cínonosných greisenů, které byly předmětem intenzivní historické těžby $v$ regionu. Primární mineralizace je vázána na hrubozrnný křemen s fluorapatitem a ojedinělým zirkonem, monazitem-(Ce) a xenotimem-(Y). Kasiterit je velmi vzácný a vedle běžných sulfidů (arsenopyrit, chalkopyrit, pyrit, sfalerit, minerály skupiny tetraedritu) se výrazně uplatňují minerály $B i$ (aikinit, bismutinit, berryit, cuprobismutit, emplektit a wittichenit). Bismut je hojně zastoupen i ve složení minerálů skupiny tetraedritu - vedle Bi-bohatého tennantitu-(Zn) a tennantitu-( $\mathrm{Fe}$ ) byly zjištěny i mikroskopické zóny představované dosud nepopsaným Bi-dominantním analogem tennantitu („annivit-(Zn)“). Obdobná, druhově bohatá Bi mineralizace byla nedávno popsána z dolu Jedová jáma u Vejprt (Pauliš et al. 2020), kde však vystupuje v odlišné geologické pozici.

Primární mineralizace byla na výskytu v Hřebečné intenzívně postižena supergenními procesy, chalkopyrit a sfalerit jsou zatlačovány sulfidy $\mathrm{Cu}$, zejména anilitem a di- genitem, vzácněji i geeritem, spionkopitem a covellínem. Část zrn fluorapatitu $v$ křemenné žilovině byla rozložena a ve vzniklých dutinách krystalizovaly mrázekit, mixit, libethenit, pseudomalachit, hydroxylpyromorfit, metatorbernit a ojedinělý dzhalindit. Nejhojnějšími supergenními fázemi jsou minerály alunitové superskupiny, z nichž byly identifikovány crandallit, goyazit, plumbogummit, svanbergit a waylandit.

\section{Poděkování}

Milou povinností autorů je poděkovat za fotografie $P$. Fuchsovi z Teplic. Předložená práce vznikla za finanční podpory Ministerstva kultury $v$ rámci institucionálního financování dlouhodobého koncepčního rozvoje výzkumné organizace Národní muzeum (DKRVO 2019-2023/1.I.c, 00023272).

\section{Literatura}

Anders E, Grevesse N (1989) Abundances of the elements: Meteoritic and solar. Geochim Cosmochim Acta 53: 197-214

Anthony JW, Bideaux RA, Bladh KW, Nichols MC (1990) Handbook of Mineralogy. Volume I Elements, Sulfides, Sulfosalts. 588 s., Mineral Data Publishing Tuscon

ArLt T, Armbruser T (1999) Single-crystal X-ray structure refinement of cornwallite, $\mathrm{Cu}_{5}\left(\mathrm{AsO}_{4}\right)_{2}(\mathrm{OH})_{4}$ : A comparison with its polymorph cornubite and the $\mathrm{PO}_{4}$-analogue pseudomalachite. $\mathrm{N}$ Jb Miner, Mh 468-480

BAU M, MölleR P (1992) Rare earth element fractionation in metamorphogenic hydrothermal calcite, magnesite and siderite. Miner Petrol 45: 231-246

Bayliss P, Kolitsch U, Nickel EH, Pring A (2010) Alunite supergroup: recommended nomenclature. Mineral Mag 74: 919-927

BERRY LG (1950) On pseudomalachite and cornetite. Am Mineral 35: 365-385

Biagioni C, George LL, Cook NJ, Makovicky E, Moëlo Y, Pasero M, Sejkora J, Stanley ChJ, Welch MD, Bosi F (2020) The tetrahedrite group: Nomenclature and classification. Am Mineral 105(1): 109-122

BORTNIKOV NS, KudRYAVTSEV AS, TRONEVA NV (1986) Bismuth-containing tetrahedrite-tennantite ores from Tary-Ekan deposit (East Karamazar, Central Asia). Mineral Žurnal 8(3): 61-64 (rusky)

Breiter K, Haková M, Schovánková D, Sokol A (1985) Ložiskové zhodnocení greizenů blatenského žulového masívu. MS Ústřední ústav geologický, P090.1985, 62 str.

Breiter K, Haková M, Sokol A (1987) Geochemical types of granites in the Blatná Massif in the Krušné hory Mts. Věst Ústř Úst geol 62: 333-349

Breiter K, Förster H-J, ŠKoda R (2006) Extreme P-, Bi-, $\mathrm{Nb}-, \mathrm{Sc}-, \mathrm{U}-$, and F-rich zircon from fractionated perphosphorus granites: The peraluminous Podlesí granite system, Czech Republic. Lithos 88: 15-34

BREITER K, FÖRSTER H-J (2021) Compositional variability of monazite-cheralite-huttonite solid solutions, xenotime, and uraninite in geochemically distinct granites with special emphasis to the strongly fractionated peraluminous Li-F-P-rich Podlesí granite system (Erzgebirge/Krušné Hory Mts., Central Europe). Minerals 11, 127

BuRnhAM CHW (1962) Lattice constant refinement. Carnegie Inst Washington Year Book 61: 132-135 
CiesielczUk J, Janeczek J, Dulski M, KrzYkaWski T (2016) Pseudomalachite-cornwallite and kipushite-philipsburgite solid solutions: chemical composition and Raman spectroscopy. Eur J Mineral 28(3): 555-569

Cook NJ (1998) Bismuth sulfosalts from hydrothermal vein deposits of Neogene age, NW Romania. Mitt Österreich Mineral Ges 143:19-39

CORDSEN A (1978) A crystal-structure refinement of libethenite. Canad Mineral: 16, 153-157

Čejka J, Sejkora J, Plášll J, Keeffe EC, Bahfenne S, PALMER SJ, Frost RL (2011) A Raman and infrared spectroscopic study of $\mathrm{Ca}^{2+}$ dominant members of the mixite group from the Czech Republic. J Raman Spectrosc 42: 1154-1159

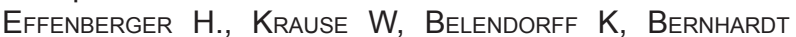
H-J, Medenbach O, Hybler J, Petříček V (1994) Revision of the crystal structure of mrázekite, $\mathrm{Bi}_{2}$ $\mathrm{Cu}_{3}(\mathrm{OH})_{2} \mathrm{O}_{2}\left(\mathrm{PO}_{4}\right)_{2} \cdot 2 \mathrm{H}_{2} \mathrm{O}$. Can Mineral 32(2): 365-372

Frost RL, ČEJKA J, SEJKora J, PLÁšIL J, Bahfenne S, PALmer SJ (2010) Raman spectroscopy of the mixite mineral $\mathrm{BiCu}_{6}\left(\mathrm{AsO}_{4}\right)_{3}(\mathrm{OH})_{6} \cdot 3 \mathrm{H}_{2} \mathrm{O}$ from the Czech Republic. J Raman Spectrosc 41: 566-570

Gablina IF, Mozgova NN, Borodaev YS, Stepanova TV, Cherkashev GA, IL'IN MI (2000) Copper sulfide association in recent oceanic ores of the Logachev hydrothermal field (Mid-Atlantic Ridge, 14 degrees 45' N). Geol Ore Depos 42: 296-316

GHOSE S (1963) The crystal structure of pseudomalachite, $\mathrm{Cu}_{5}\left(\mathrm{PO}_{4}\right)_{2}(\mathrm{OH})_{4}$. Acta Cryst 16: 124-128

GoBLE RJ (1980) Copper sulfides from Alberta: yarrowite $\mathrm{Cu}_{9} \mathrm{~S}_{8}$ and spionkopite $\mathrm{Cu}_{39} \mathrm{~S}_{28}$. Can Mineral 18: 511518

Goble RJ (1981) The leaching of copper from anilite and the production of metastable copper sulfide structure. Can Mineral 19: 583-592

Goble RJ, Robinson G (1980) Geerite, $\mathrm{Cu}_{1.60} \mathrm{~S}$, a new copper sulfide from Dekalb township, New York. Can Mineral 18: 519-523

Gotęionska B, Pieczka A, Parafiniuk J (2012) Substitution of $\mathrm{Bi}$ for $\mathrm{Sb}$ and $\mathrm{As}$ in minerals of the tetrahedrite series from Rędziny, Lower Silesia, southwestern Poland. Can Mineral 50: 267-279

Grey IE, Mumme WG, Bordet P, Mills SJ (2008) A new crystal-chemical variation of the alunite-type structure in monoclinic $\mathrm{PbZn}_{0.5} \mathrm{Fe}_{3}\left(\mathrm{AsO}_{4}\right)_{2}(\mathrm{OH})_{6}$. Can Mineral 46: 1355-1364

Grønvold F, Westrum EF (1980) The anilite/low digenite transition. Am Mineral 65: 574-575

Gu X, Watanabe M, Ohkawa M, Hoshino K, Shibata Y, Chen D (2001) Felbertalite and related bismuth sulfosalts from the Funiushan copper skarn deposit, Nanjing, China. Can Mineral 39: 1641-1652

GüntHER R (1857) Die St. Mauritzi Zeche oder das Behrische Werk am alten Hengst bei Abertham i. Böh. MS Geofond, Praha K000129, 36 s

HÁJEK J (2017) Historie dobývání cínu v dole Mauritius na Zadní Hřebečné. Vývoj těžby na konci 19. století a v první polovině 20. století. MS dipl. práce Filosofická fakulta Masarykovy univerzity Brno $102 \mathrm{~s}$.

HATERT F (2005) Transformation sequences of copper sulfides at Vielsalm, Stavelot Massif, Belgium. Can Mineral 43: 623-635

HEŘMANSKÁ M (2013) Minerální asociace, alterační reakce a transportní model pro vznik greisenů blatenského granitového masívu v Krušných horách. MS dipl. práce PřF Univerzita Karlova Praha
HutTon CO (1959) An occurrence of pseudomalachite at Safford, Arizona. Am Mineral 44: 1298-1301

IRBER W (1999) The lanthanide tetrad effect and its correlation with $\mathrm{K} / \mathrm{Rb}, \mathrm{Eu} / \mathrm{Eu}^{*}, \mathrm{Sr} / \mathrm{Eu}, \mathrm{Y} / \mathrm{Ho}$, and $\mathrm{Zr} / \mathrm{Hf}$ of evolving peraluminous granite suites. Geochim Cosmochim Acta 63(3-4): 489-508

JAMBOR JL (1999) Nomenclature of the alunite supergroup. Can Mineral 37: 1323-1341

JAMBOR JL, DUtRIZAC JE (1983) Beaverite-plumbojarosite solid solutions. Can Mineral 21: 101-113

JANGL L (1975) Vývoj dolování v blatenském revíru v Krušných horách ve 14. až 19. století. Studie z dějin hornictví 6: 65-83

JANGL L (1988) Báňskohistorická studie oblasti Rolava -Přebuz-Hřebečná (Sn-W). MS Geofond Kutná Hora. GKH 231

Jangl L, HašKová K, Lisková S (1989) Rolava-Hřebečná, část Hřebečná. MS Geofond, Kutná Hora GKH 235

JEŽEK B (1933) Cínovcové doly u Hengstererben v Krušných horách. Hornický věstník 15: 33-38, 60-65, 8386, 105-107, 154-156

KARUP-MølLeR S (1977) Mineralogy of some Ag-(Cu)-PbBi sulphide associations. Bull Geol Soc Denmark 26: 41-68

KIEFT K, ERIKSSON G (1984) Regional zoning and metamorphic evolution of the Vindfall $\mathrm{Pb}-\mathrm{Zn}$ ore, east central Sweden. Geol Fören Stockholm Förh 106: 305-317

KLÜNDER MH, KaRUP-MøLleR S, MaKovicky E (2003) Exploratory studies on substitutions in the tetrahedritetennantite solid solution series. III. The solubility of bismuth in tetrahedrite-tennantite containing iron and zinc. N Jb Mineral, Mh: 153-175

KnižKovÁ-Drbohlavová J, Roos E, Strnad J (1970) Závěrečná zpráva o výzkumu ložisek cínových rud blatenského žulového masívu. MS Geofond, Praha P022179, $101 \mathrm{~s}$

KomÁREK M (1965) Nerostné bohatství Krušných hor. Nár muz a Spol Nár muz $22 \mathrm{~s}$.

KOMÁREK M (1968) Mineralogie a petrografie greisenů blatenského žulového masivku. MS dipl. práce PřF Univerzita Karlova Praha

Kolitsch U, PRINg A (2001) Crystal chemistry of the crandallite, beudantite, and alunite groups: A review and evaluation of the suitability as storage materials for toxic metals. J Miner Petrol Sci 96: 67-78

KRATOCHVíl F (1965) Některé minerály $z$ wolframitových a cínovcových ložisek $v$ jihozápadních Krušných horách. Čas Nár Muz, Ř prírodověd 134, 1: 54-60

KRATochVil F (1967) Cínovcové ložisko Starý Hengst u Hřebečné v Krušných horách. Čas Nár Muz, Ř přírodověd: $140-147$

KRATOCHVIL J (1958) Topografická mineralogie Čech II. (heslo Hengstererben). NČSAV Praha

KRETSCHMAR U, ScotT SD (1976) Phase relations involving arsenopyrite in the system Fe-As-S and their application. Can Mineral 14: 364-386

Lafuente B, Doens RT, Yang H, Stone N (2015) The power of databases: the RRUFF project. In: ARMBRUSTER T, DANISI RM, eds. (2015) Highlights in Mineralogical Crystallography: 1-30, W. De Gruyter, Berlin

LAUBE G (1876) Geologie des böhmischen Erzgebirges. I. Theil: Geologie des westlichen Erzgebirges oder des Gebirges zwischen Maria-Kulm-Schönbach und Joachimsthal. Gottesgab Arch Naturwiss Landes-Durchforsch Böhm, III, 2: 1-280 
Litochleb J, SeJkora J, Srein V, Malec J (2009) Kašperskohorské zlato (Šumava, Česká republika). Bull mineral-petrolog odd Nár Muz (Praha) 17(1): 1-13

MAKOVICKY E (2019) Algorithms for calculations of homologue order $\mathrm{N}$ in the homologous series of sulfosalts. Eur J Mineral 31(1): 83-97

MAKOVICKY E, MAKOVICKY M (1978) Representation of compositions in the bismuthinite-aikinite series. Can Mineral 16: 405-409

MALÝ KD, SEJKORA J (2004) Supergenní Cu a Bi mineralizace na lokalitě Tři Sekery u Mariánských Lázní. Bull mineral-petrolog Odd Nár Muz (Praha) 12: 136-139

McLenNAN SM (1989) Rare earth elements in sedimentary rocks: influence of provenance and sedimentary processes. Rev Mineral 21: 169-200

Mereiter K, Preisinger A (1986) Kristallstrukturdaten der Wismutminerale Atelestit, Mixit und Pucherit. Oest Akad Wissen, math - naturwiss KI 123, 79-81

Mills SJ, Grey IE, Mumme WG, Miawaki R, Matsubara S, Bordet P, BIRCH WD, Raudsepp M (2008) Kolitschite, $\mathrm{Pb}\left[\mathrm{Zn}_{0.5} \square_{0.5}\right] \mathrm{Fe}_{3}\left(\mathrm{AsO}_{4}\right)_{2}(\mathrm{OH})_{6}$, a new mineral from the Kintore opencut, Broken Hill, New South Wales. Austral J Mineral 14: 63-67

MoRImOTO N, Kato K (1970) Phase relations of the Cu-S system at low temperatures: stability of anilite. Am Mineral 55: 106-117

Mumme WG, SparRow GJ, Walker GS (1988) Roxbyite, a new copper sulphide mineral from the Olympic Dam deposit, Roxby Downs, South Australia. Mineral Mag 52: 323-330

Nesrsta M, Urban M, Weber N (2015) Důl Mauritius v Hřebečné. Stavebně - historický průzkum. Abertamy

NovÁK F, ZAHRADNíK K (1962) Geochemicko-prospekční průzkum india. MS ÚNS Kutná Hora P015549, $418 \mathrm{~s}$

OKrusch M, LORENZ JA, WeYER S (2007) The genesis of sulfide assemblages in the former Wilhemine mine, Spessart, Bavaria, Germany. Can Mineral 45: 723750

Olds TA, Kampf AR, Rakovan JF, Burns PC, Mills OP, LauGHLIN-YURS C (in print) Hydroxylpyromorphite, modern description and characterization of a mineral important to lead-remediation. Am Mineral preprint, doi:10.2138/ am-2021-7516

Olmi F, Sabelli C, Trostı Ferroni R (1991) A contribution to the crystal chemistry of mixite group minerals from Sardinia (Italy). N Jb Mineral, Mh: 487-499

ONDRUŠ P (1993) ZDS - A computer program for analysis of X-ray powder diffraction patterns. Materials Science Forum: 133-136, 297-300, EPDIC-2. Enschede

OndRuš P, Veselovský F, HLoušeK J, SkÁla R, VAVŘín I, FrÝDA J, ČEJKA J, GaBAšovÁ A (1997) Secondary minerals of the Jáchymov (Joachimsthal) ore district. J Czech Geol Soc 42(4): 3-76

Pauliš P, Urban M, Sejkora J, Hloušek J, Pour O (2015) Cínový revír Hřebečná v Krušných horách a jeho mineralogie. Minerál 23(4): 328-338

Pauliš P, DolničEk Z, GrambličKa R, Pour O (2020) Neobvyklá žilná Cu-Zn-Ag-Pb-As-Sb-Se-Sn-Bi mineralizace z Jedové jámy u Vejprt v Krušných horách (Česká republika). Bull Mineral Petrolog 28(2): 385-405

PlÁšIL J, SEJKORA J, ČEJKA J, ŠKÁCHA P, Goliáš V (2009) Supergene mineralization of the Medvědín uranium deposit, Krkonoše Mountains, Czech Republic. J Geosci 54: $15-56$
Pouchou J, PICHOIR F (1985) „PAP“ ( $\varphi \rho z)$ procedure for improved quantitative microanalysis. In: Armstrong JT (ed): Microbeam Analysis: 104-106. San Francisco Press San Francisco

Rattray KJ, Taylor MR, Bevan DJM, Pring A (1996) Compositional segregation and solid solution in the lead-dominant alunite-type minerals from Broken Hill, N.S.W. Mineral Mag 60: 779-785

RENÉ M (2014) Composition of coexisting zircon and xenotime in rare-metal granites from the Krušné Hory/ Erzgebirge Mts. (Saxothuringian Zone, Bohemian Massif). Miner Petrol 108: 551-569

ScotT KM (1987) Solid solution in, and classification of, gossan-derived members of the alunite-jarosite famiIy, northwest Queensland, Australia. Am Mineral 72: 178-187

SeJKora J, Šrein V (1996) Príspěvek ke krystalochemii mixitu z lokalit Českého masívu. Zpr geol výzk v r 1995: 153-155

Sejkora J, Gabašová A, Novotná M (1997) Mixit ze Smrkovce u Mariánských Lázní. Bull mineral-petrolog Odd Nár Muz (Praha) 4-5: 185-187

SEJKora J, ŘídKošIL T, Šrein V (1999) Zálesíite, a new mineral of the mixite group, from Zálesí, Rychlebské hory Mts., Czech Republic. N Jb Mineral, Abh 175(2): 105-124

SEJKORA J, ČEJKA J, ŠreIN V (2001) Pb dominant members of crandallite group from Cínovec and Moldava deposits, Krušné hory Mts. (Czech Republic). J Czech Geol Soc 46(1-2): 53-68

Sejkora J, Ondruš P, Fikar M, Veselovský F, Mach Z, GaBAŠová A, ŠKoda R, Beran P (2006) Supergene minerals at the Huber stock and Schnöd stock deposits, Krásno ore district, the Slavkovský les area, Czech Republic. J Czech Geol Soc 51: 57-101

Sejkora J, Škovíra J, Čejka J, PlÁšll J (2009) Cu-rich members of the beudantite-segnitite series from the Krupka ore district, the Krušné hory Mountains, Czech Republic. J Geosci 54: 355-371

Sejkora J, Pauliš P, Malíková R, Zeman M, Krtek V (2013) Supergenní minerály As ze štoly č. 2 Preisselberg, rudní revír Krupka (Česká republika). Bull mineral-petrolog Odd Nár Muz (Praha) 21: 201-209

Sejkora J, Števko M, Ozdín D, Pršek S, Jeleñ J (2015) Unusual morphological forms of hodrusite from the Rozália vein, Hodruša-Hámre near Banská Štiavnica (Slovak Republic). J Geosci 60(1): 11-22

SeJKora J, ŠKácha P, KopeckÝ S Sen, KopeckÝ S Jun, PAuliš P, Malíková R, Velebil D (2016) Se a Cu mineralizace z Bílé Vody u Javorníka (Česká republika). Bull mineral-petrolog Odd Nár Muz (Praha) 24(2): 161-177

Sejkora J, Pauliš P, Gramblička R, Malíková R, Pour O, DolničEK Z, Ulmanová J, VRTIŠKA L (2019) Nově zjištěná Bi-Co-Ni-As-U-V mineralizace přísečnického rudního revíru v Krušných horách (Česká republika). Bull Mineral Petrolog 27(1): 1-37

Sharp ZD, Essene EJ, Kelly WC (1985) A re-examination of the arsenopyrite geothermometer: pressure considerations and applications to natural assemblages. Can Mineral 23: 517-534

Shoemaker GL, Anderson JB, Kostiner E (1981) The crystal structure of a third polymorph of $\mathrm{Cu}_{5}\left(\mathrm{PO}_{4}\right)_{2}(\mathrm{OH})_{4}$. Am Mineral 66: 169-175

SCHALLER J (1785) Topographie des Königsreichs Böhmens. Díl II. Praha 
SchANDL ES, GoRTon MP (2004): A textural and geochemical guide to the identification of hydrothermal monazite: criteria for selection of samples for dating epigenetic hydrothermal ore deposits. Econ Geol 99: 1027-1035

Spiridonov EM, ChVileva TN, Borodaev YS, Vinogradova RA, Kononov OV (1986) The influence of bismuth on optical properties of fahlores. Dokl Akad Nauk SSSR 290: 1475-1478 (rusky)

ŠKÁCHA P, SEJKORA J (2013) Výskyt cinnabaritu s mikroskopickým gortdrumitem na ložisku Vrančice u Příbrami (Česká republika). Bull mineral-petrolog odd Nár Muz (Praha) 21(1): 57-61

ŠKvoR V (1975) Geologie české části Krušných hor a Smrčin. ÚÚG Praha

ŠteVko M, SeJKora J (2012) Supergene arsenates of copper from Špania Dolina-Piesky deposit, central Slovakia. Acta Mineral-Petrograph, Abstract Ser 7: 130

ŠteVko M, SeJkora J (2014) Contribution to chemical composition of chalcophyllite, pseudomalachite and olivenite group minerals from Špania Dolina-Piesky, Slovak Republic. Book of abstracts, CEMC 2014, 133-134

ŠteVko M, SEJKora J, Ozdín D (2008) Henclová - nová lokalita pseudomalachitu v Slovenskej republike. Bull mineral-petrolog Odd Nár Muz (Praha) 16: 36-39

ŠteVko M, SeJKora J, Malíková R (2016) Nové údaje o supergénnych mineráloch z banského pol'a Rainer, ložisko L'ubietová - Podlipa (Slovenská republika). Bull mineral-petrolog Odd Nár Muz (Praha) 24(1): 1-12

Števko M, SEJKora J, Súlovec Š (2017) Príspevok k chemickému zloženiu libethenitu z typovej lokality: ložisko Podlipa, L'ubietová (Slovenská republika). Bull Mineral Petrolog 25(2): 252-259

ŠteVko M, SeJkora J, DolničEK Z (2020) Pseudomalachit z lokality Zadné Breziny pri Gemerskej Polome (Slovenská republika). Bull Mineral Petrolog 28(2): 290-294

Tanaka T, Minakawa T, Kusachi I, Tanabe M (2009) Bi-bearing and REE-free zálesíte from the Fuka mine, Okayama Prefecture, Japan. J Mineral Petrolog Sci 104(3): 164-167

Toman J, Hrazdil V, Sejkora J (2016) Pseudomalachit a descloizit $v$ supergenní mineralní asociaci z lokality Krucemburk (Česká republika). Acta Mus Moraviae, Sci geol 101(1-2): 33-43

Topa D, Makovicky E, PAAR WH (2002) Composition ranges and exsolution pairs for the members of the bismuthinite-aikinite series from Felbertal, Austria. Can Mineral 40(3): 849-869

Topa D, Makovicky E, Balič-Zunič T (2003a) Crystal structures and crystal chemistry of members of the cuprobismutite homologous series of sulfosalts. Can Mineral 41: 1481-1501
Topa D, Makovicky E, Balič-Zunič T, PaAR WH (2003b) Kupčíkite, $\mathrm{Cu}_{3.4} \mathrm{Fe}_{06} \mathrm{Bi}_{5} \mathrm{~S}_{10}$, a new sulfosalt from Felbertal, Austria, and its crystal structure. Can Mineral 41: 1155-1166

Topa D, Makovicky E, Putz H, Mumme WG (2006) The crystal structure of berryite, $\mathrm{Cu}_{3} \mathrm{Ag}_{2} \mathrm{~Pb}_{3} \mathrm{Bi}_{7} \mathrm{~S}_{16}$. Can Mineral 44(2): 465-480

TuČEK K (1948) Nové nálezy nerostů II. Příspěvky k topografické mineralogii. Věst Král Čes Společ Nauk, Tř mat-prírodověd 13: 1-25

URBAN M, MaLina O (2013) Vodní hospodářství v cínovém revíru Hřebečná. In: Proměny montánní krajiny: 162179, NPÚ Loket

URBAN M, MaLINA O (2014) Strukturní pozice greisenových žil v blatenském masívu v Krušných horách. ArchaeoMontan 2013, Arbeits- und Forschungsberichte zur sächsischen Bodendenkmalpflege 28: 19-30. Dresden.

URBAN M, editor (2014) Horní města Krušných hor. 1. díl Karlovarský kraj. Fornica publishing, Sokolov

Urban M (2015) Důl Mauritius na Hřebečné (Die Grube Mauritius auf Hřebečná). TU Bergakademie Freiberg

Velebil D, SeJKora J (2018) Bismutem bohaté tennantity z Jáchymova (Česká republika). Bull Mineral Petrolog 26(2): 213-222

VRtišKa L, Sejkora J, Malíková R (2016) Philipsburgit z Krásna u Horního Slavkova, Slavkovský les (Česká republika). Bull mineral-petrolog Odd Nár Muz (Praha), 24(2): 243-251

VRtišKa L, Malíková R, Dolní̌̌ek Z, Sejkora J (2019) Pyromorfit, kintoreit a cerusit $\mathrm{z}$ historického $\mathrm{Ag}-\mathrm{Pb}-\mathrm{Zn}$ ložiska Ratibořské Hory (Česká republika). Bull Mineral Petrolog 27(2): 394-410

Yakubovich OV, MeL'NIKov OK, Wester D (1993) Libethenite $\mathrm{Cu}_{2}\left(\mathrm{PO}_{4}\right) \mathrm{OH}$ : synthesis, crystal-structure refinement, and comparative crystal chemistry. Crystallogr reports 38(1): 32-36

Yvon K, JeitschKo W, PARthé E (1977) Lazy Pulverix, a computer program for calculation X-ray and neutron diffraction powder patterns. J Appl Cryst 10: 73-74

Zema M, Tarantino SC, Callegari AM (2010) Thermal behaviour of libethenite from room temperature up to dehydration. Mineral Mag 74: 553-565

ZHu XK, O'NıONS RK (1999) Monazite chemical composition: some implications for monazite geochronology. Contrib Mineral Petrol 137: 351-363 